\title{
Unconventional, amphiphilic polymers based on chiral poly(ethylene oxide) derivatives I. Synthesis and Characterization
}

\author{
Citation for published version (APA): \\ Janssen, H. M., Peeters, E., Zundert, van, M. F., Genderen, van, M. H. P., \& Meijer, E. W. (1997). \\ Unconventional, amphiphilic polymers based on chiral poly(ethylene oxide) derivatives I. Synthesis and \\ Characterization. Macromolecules, 30(26), 8113-8128. https://doi.org/10.1021/ma970938I
}

DOI:

10.1021/ma970938I

Document status and date:

Published: 01/01/1997

\section{Document Version:}

Publisher's PDF, also known as Version of Record (includes final page, issue and volume numbers)

\section{Please check the document version of this publication:}

- A submitted manuscript is the version of the article upon submission and before peer-review. There can be important differences between the submitted version and the official published version of record. People interested in the research are advised to contact the author for the final version of the publication, or visit the DOI to the publisher's website.

- The final author version and the galley proof are versions of the publication after peer review.

- The final published version features the final layout of the paper including the volume, issue and page numbers.

Link to publication

\footnotetext{
General rights

- You may freely distribute the URL identifying the publication in the public portal. follow below link for the End User Agreement:

www.tue.nl/taverne

\section{Take down policy}

If you believe that this document breaches copyright please contact us at:

openaccess@tue.nl

providing details and we will investigate your claim.
}

Copyright and moral rights for the publications made accessible in the public portal are retained by the authors and/or other copyright owners and it is a condition of accessing publications that users recognise and abide by the legal requirements associated with these rights.

- Users may download and print one copy of any publication from the public portal for the purpose of private study or research.

- You may not further distribute the material or use it for any profit-making activity or commercial gain

If the publication is distributed under the terms of Article $25 \mathrm{fa}$ of the Dutch Copyright Act, indicated by the "Taverne" license above, please 


\title{
Unconventional, Amphiphilic Polymers Based on Chiral Poly(ethylene oxide) Derivatives. I. Synthesis and Characterization $^{1}$
}

\section{H. M. J anssen, E. Peeters, M. F. van Zundert, M. H. P. van Genderen, and E. W. Meijer*}

Laboratory of Organic Chemistry, E indhoven University of Technology, P.O. B ox 513, 5600 MB, The Netherlands

Received J une 26, 1997; Revised Manuscript Received October 9, $1997^{\otimes}$

\begin{abstract}
The first representatives of a new class of synthetic, amphiphilic polymers-polyethylene oxide-based (PEO-based) polymers 1-3, (see Figure 2)-are introduced. These polymers are constituted in a similar way as coiled-coil-forming peptides: the polymers possess a regular repeat of apolar (A) residues in a polar $(P)$ sequence of residues. Polymers 1-3 can thus be characterized by the formula [PAPPAPP' $]_{n}$ or $\left[\mathrm{PAPP}^{\prime}\right]_{\mathrm{n}}$, in which $\mathrm{P}$ stands for an ethylene oxide unit, $\mathrm{P}^{\prime}$ stands for a glycate unit, and A stands for a hydrophobically modified ethylene oxide unit. The preparation of $\mathbf{1}-\mathbf{3}$ comprises the synthesis and SnOct $_{2}$-catalyzed ring-opening polymerization of 2-oxo-crown ether monomers (SS)-4, (S)5, and (S)-6. Alternatively, polymers 1-3 have been obtained by the polycondensation of their $\omega$-hydroxycarboxylic acid precursors. ${ }^{1} \mathrm{H}$ NMR and ${ }^{13} \mathrm{C} N \mathrm{NR}$ analysis as well as electrospray mass spectrometry (ES-MS) verified the integrity of the fol lowed synthetic route and, therefore, confirmed the regular repeat of polar and apolar segments in 1-3. The critical aggregation concentrations (cac's) of 1-3 in $\mathrm{H}_{2} \mathrm{O}$ at $20^{\circ} \mathrm{C}$ were determined by a fluorescence study, using pyrene as an apolar fluorescent probe. The cac's (i) were strongly influenced by the size of the hydrophobic segments in the pol ymer and by the frequency at which these segments were repeated in the polymer and (ii) varied over a wide concentration range (i.e. polymer 1 displayed a cac of ca. $0.002 \mathrm{mg} / \mathrm{mL}$, whereas polymer 3 showed a cac of ca. $0.15 \mathrm{mg} / \mathrm{mL}$ ). Thus, tailoring of the cac is possible in these new synthetic, amphiphilic polymers.
\end{abstract}

\section{Introduction}

Amphiphilic polymers are of fundamental scientific interest and find their use in industrial applications. Over the years, many of these polymers, in which hydrophilic (or polar) and hydrophobic (or apolar) segments are combined, have been investigated. Amphiphilic polymers can be obtained by alternating hydrophilic and hydrophobic blocks, as exemplified in frequently studied block copolymers such as polystyrene/ poly(sodium acrylate) (PS/PANa), polystyrene/poly(ethylene oxide) (PS/PEO), and poly(ethylene oxide)/ poly(propylene oxide) (PEO/PPO/PEO). ${ }^{2}$ Other approaches to acquire amphiphilic polymers include the copolymerization of monomers of opposing polarity or the postmodification of polymers. ${ }^{3}$ Recently, special architectures have been employed to construct new amphiphiles in general and new amphiphilic polymers in particular; ${ }^{4}$ dendrimers and star polymers, for instance, have been used in the synthesis of amphiphiles. ${ }^{5}$ All these approaches have added to a better understanding of the structure-property relationship in amphiphilic (macro)molecules, but up to date, no general theory has been put forward to describe the behavior of amphiphiles. Therefore, an increased control over the properties of amphiphiles remains in demand, especially regarding the highly specific functions that are possible for amphiphiles, as exemplified in some vital natural systems (e.g. phospholipid bilayers in cell membranes and enzymes in which hydrophobic microdomains serve as specific receptor sites).

A unique 'ribbon'-type of amphiphilicity is observed in coiled-coil-forming peptides such as myosin. ${ }^{6}$ Myosin has a $7_{2}$-repeat of apolar (A) amino acids in a polar (P) sequence of amino acids and can therefore be

\footnotetext{
1997.

${ }^{\otimes}$ Abstract published in Advance ACS Abstracts, December 15,
}

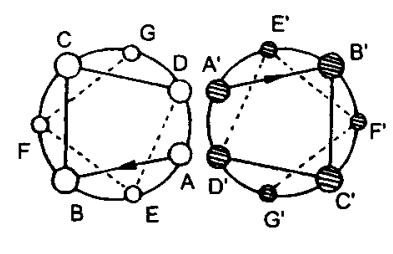

A

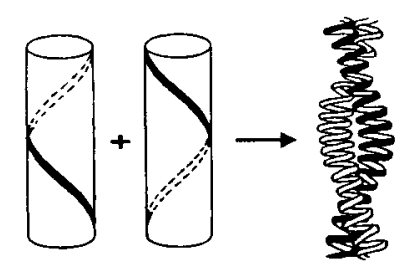

B
Figure 1. Coiled coil representations. The 'helical wheel' representation (part A) is an end-on-view of two $\alpha$-helices that build up a coiled coil. In every 'wheel', the repeating unit of seven amino acids is drawn. Positions $A$ and $D$ (and $A$ ' and $\left.D^{\prime}\right)$ are occupied by hydrophobic residues such as leucine (Leu), while positions B, C, and D (and B', $C^{\prime}$, and $D^{\prime}$ ) are occupied by hydrophilic, $\alpha$-helix-stabilizing residues such as serine (Ser). Finally, positions $E$ and $G$ (and $E^{\prime}$ and $G^{\prime}$ ) are occupied by lysine (Lys) and glutamic acid (Glu), which at the right $\mathrm{pH}$ give salt bridges between the two $\alpha$-helical units of the coiled coil. ${ }^{39}$ The association process is schematically drawn in part B. In $\mathrm{H}_{2} \mathrm{O}$, the apolar ribbons on the surfaces of the amphiphilic $\alpha$-helices-for simplicity drawn as cylinders-'click' together, thereby deforming the two helices to two left-handed superhelices. After association, the ribbons are buried in the interior of the coiled coil and are thus shielded from the aqueous environment.

characterized by the formula [PAPPAPP $]_{n}$. This typical $7_{2}$-repeat gives rise to $\alpha$-helical peptides with a hydrophobic ribbon al ong the surface of the $\alpha$-helix, causing the association of two peptide macromolecules to a double superhelix-a so-called coiled coil (see Figure 1).

To our knowledge, the design of nonpeptide, synthetic polymers with a potential 'ribbon'-type of amphiphilicity has never been addressed. A first approach to such synthetic analogues of coiled coils is presented here and involves the synthesis of the chiral, PEO-based polymers shown in Figure 2. The choice of the PEO-based target polymers 1-3-the ester function in the backbone has been introduced for synthetic reasons-is inspired by the solubility and the dominantly hydrophilic behavior of 

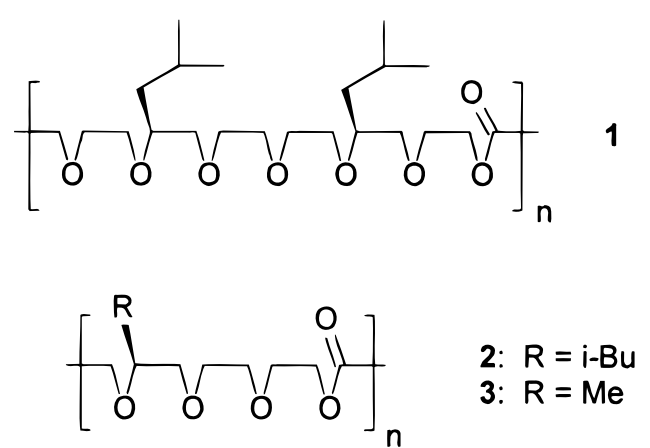

Figure 2. Synthetic coiled-coil analogues based on PEO. I sobutyl side groups are chosen in analogy to the isobutyl side groups of the leucine residues in coiled-coil-forming peptides. The methyl side groups are chosen analogous to the methyl side groups in PEO/PPO/PEO block copolymers. Chirality is introduced in analogy to the chirality present in peptides. Polymer $\mathbf{1}$ and polymers $\mathbf{2}$ and $\mathbf{3}$ can be abbreviated in the formulas [PAPPAPP'] and [PPAP'] $]_{n}$, respectively.

PEO in $\mathrm{H}_{2} \mathrm{O}$ and by the $7_{2}$-helical conformation of PEO in dilute aqueous solutions. In contrast, PPO and poly(butylene oxide) (PBO) are hardly soluble in $\mathrm{H}_{2} \mathrm{O}$, whereas PEO/PPO/PEO as well as PE O/PBO/PEO block copolymers show distinct amphiphilic behavior. ${ }^{8}$ Therefore, ethylene oxide fragments are regarded as polar (or hydrophilic), whereas alkyl-substituted ethylene oxide fragments are apolar (or hydrophobic). Consequently, stereoregular placing of isobutyl side chains at every second and fifth unit of a seven-unit repeat of ethylene oxides-as shown in polymer 1-results in a synthetic analogue of coiled-coil-forming polypeptides, in the sense that the design of the primary structure is identical. Polymers $\mathbf{2}$ and 3, both having a [PAPPAPP']resembling [PPAP']-repeat in the primary structure, can be used to investigate the structure-property relationship in this type of polymers.

This paper reports on (i) the synthesis of polymers 1-3, (ii) the molecular characterization of 1-3 and their precursors by ${ }^{1} \mathrm{H} N \mathrm{NMR},{ }^{13} \mathrm{C} N M R$, chromatography techniques, and electrospray mass spectrometry (ESMS) and (iii) experimental evidence for the amphiphilic behavior of macromolecules 1-3 in aqueous solutions. This evidence includes the determination of the critical association concentrations (cac's) of $\mathbf{1}-\mathbf{3}$ in $\mathrm{H}_{2} \mathrm{O}$ at 20 ${ }^{\circ} \mathrm{C}$ by fluorescent-probe measurements, employing pyrene as the fluorescent apolar probe. Whether these synthetic polymers 1-3 form well-defined higher structures such as coiled coils will be discussed in the second part of this article sequence.

\section{Results and Discussion}

Synthesis of the Alkyl-Modified Oxo-Crown Ethers (SS)-4, (S)-5, and (S)-6. The synthesis of oxocrown monomers (SS)-4, (S)-5, and (S)-6 is shown in Schemes $1-3$. The reactions and compounds shown in Scheme 1 have partially been reported in the literature. 9,10

The chiral and apolar fragments in the final crown ethers-the isobutyl- and methyl-substituted ethylene oxide fragments-have been introduced by starting the syntheses with either (S)-leucine or ethyl (S)-lactate (both these compounds (S)-7 and (S)-10 are commercially available). Conversion of leucine ((S)-7) by sequential diazotation $\left(\mathrm{H}_{2} \mathrm{SO}_{4} / \mathrm{NaNO}_{2} / \mathrm{H}_{2} \mathrm{O}\right)$ and esterification with $\mathrm{EtOH}$ gave ethyl (S)-leucate (9). Protection of esters (S)-9 and (S)-10 with 3,4-dihydro-2H -pyran (DHP), employing p-toluenesulfonic acid ( $\mathrm{TsOH})$ as catalyst in $\mathrm{Et}_{2} \mathrm{O}$, yielded the tetrahydropyranoxy (THP) ethyl esters (S)-11 and (S)-12 in almost quantitative yields. Reduction of these compounds using $\mathrm{LiAlH}_{4}$ in $\mathrm{Et}_{2} \mathrm{O}$ afforded the THP-monoprotected alkyl-substituted chiral diols (S)-13 and (S)-14. Williamson syntheses of these primary alcohols with 2-(2-(benzyloxy)ethoxy)ethyl tosylate (compound 37) ${ }^{11}$ in boiling THF using $\mathrm{KOH}$ as base and consecutive removal of the THP group gave the secondary alcohols (S)-15 and (S)-16. Coupling with tert-butyl bromoacetate in tert-BuOH, using tertBuOK to create the alkoxide, gave the tert-butyl esters (S)-17 and (S)-18 in satisfactory yields of $72 \%$ and $78 \%$, respectively. Acid-catalyzed hydrolysis of the tert-butyl esters and hydrogenation of the benzyl groups gave the $\omega$-hydroxycarboxylic acids (S)-21 and (S)-22 in almost quantitative yields. The final cyclization step was achi eved by heating the appropriate $\omega$-hydroxycarboxylic acid precursor with the Lewis acid $\mathrm{CoCl}_{2}(\gg 11 \mathrm{~mol}$ $\%$ ) at $250{ }^{\circ} \mathrm{C}$ in a Kugelrohr apparatus. ${ }^{12} \mathrm{An}$ almost pure distillate could be collected, when reduced pressures of 2-3 and $8 \mathrm{mmHg}$ were applied for (S)-21 and (S)-22, respectively. Chromatography afforded the 2-oxo12-crown-4 compounds (S)-5 and (S)-6 in yields of $72 \%$ and $56 \%$, respectively. For comparison, the high dilution cyclization method of Mukaiyama ${ }^{13}$ was used to synthesize compound (S)-5: the 2-oxo-12-crown-4 product was obtained in an inferior yield of $34 \%$ (additionally, 7\% dimeric product was isolated).

In Schemes 2 and 3, the synthesis of the larger 2-oxo21-crown-7 monomer (SS)-4 is shown. Alcohol (S)-13 was coupled with 2-(benzyloxy)ethyl tosylate (compound 34) ${ }^{14}$ in refluxing THF using $\mathrm{KOH}$ as base. After workup, the crude product was treated with $\mathrm{TsOH}$ in $\mathrm{MeOH}$ to remove the THP group. Thus, ether (S)-23 was obtained in a $77 \%$ yield. The convenient etherification method to produce (S)-23 $(\mathrm{KOH}, \mathrm{THF}$, reflux)-similarly applied in the syntheses of (S)-15 and (S)-16-was introduced by Selve, who used it for the production of nonionic fluoro surfactants. ${ }^{15}$ When these coupling conditions are applied to the reaction of a secondary alcohol with a primary tosylate-as in the syntheses of compounds (S)-24 and (S)-25-more equivalents of tosylate and longer reaction times have to be employed to reach reasonable yields $(40 \%$ and $67 \%$ for (S)-24 and (S)-25, respectively). Evidently, more byproducts such as hydrolyzed material are formed in these cases. Standard reaction conditions were used to debenzylate (S)-25 to al cohol (S)-26 and to tosylate (S)$\mathbf{2 4}$ to (S)-27. Finally, ethylene oxide oligomer (SS)-28 could be obtained from alcohol (S)-26 and tosylate (S)$\mathbf{2 7}$ in a 68\% yield by applying the previously described reaction conditions for Williamson syntheses $(\mathrm{KOH}$, THF, reflux).

The $\mathrm{ZnBr}_{2}$-catalyzed removal of the methoxyethoxymethylene (MEM) group in compound (SS)-28 was achieved in a poor yield of only $44 \%$ (see Scheme 3 ). The reaction did not proceed to completion, and debenzylation occurred simultaneously ( $7 \% \alpha, \omega$-diol side-product (SS)-33 was isolated). The primary alcohol (SS)-29 was coupled with tert-butyl bromoacetate to introduce an ester function. Sequential hydrolysis of the tert-butyl ester and hydrogenation of the benzyl group were conducted using standard reaction conditions. A newly developed and simplified version of a ring closure procedure reported by Corey ${ }^{16}$ could be used for the final cyclization to (SS)-4: at a concentration of $0.03 \mathrm{M}$, $\omega$-hydroxycarboxylic acid (SS)-32 was stirred for 3 days in xylene in the presence of 1.5 mol equiv of dithiodipyr- 

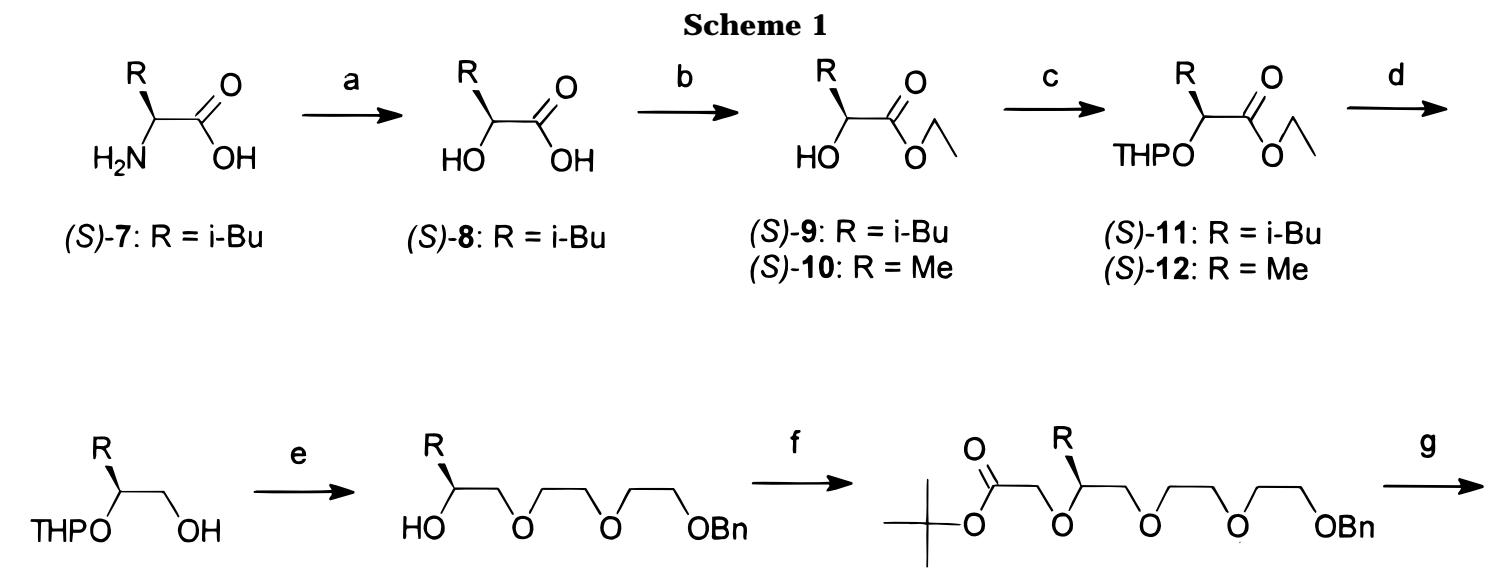
(S)-13: $\mathrm{R}=\mathrm{i}-\mathrm{Bu}$
(S)-15: $\mathrm{R}=\mathrm{i}-\mathrm{Bu}$
(S)-17: $\mathrm{R}=\mathrm{i}-\mathrm{Bu}$
(S)-14: $\mathrm{R}=\mathrm{Me}$
(S)-16: $R=M e$
(S)-18: $R=M e$

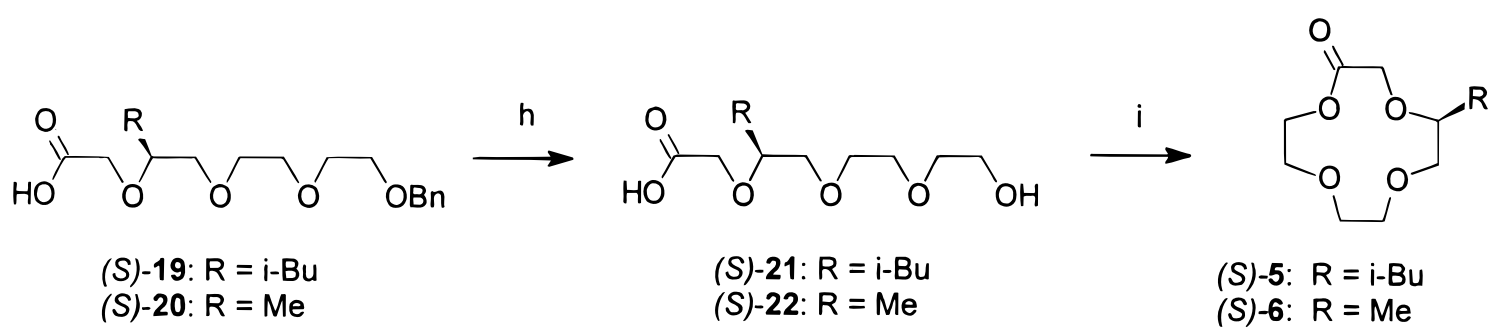

(a) $\mathrm{NaNO}_{2}, \mathrm{H}_{2} \mathrm{SO}_{4}, \mathrm{H}_{2} \mathrm{O}, \mathrm{RT}$ (54\%); (b) EtOH, HCl, PhMe, $\Delta$ (75\%); (c) DHP, TsOH, Et ${ }_{2} \mathrm{O}, \mathrm{RT}$ (87\%, 95\%); (d) $\mathrm{LiAlH}_{4}, \mathrm{Et} 2 \mathrm{O}, \mathrm{RT}$ (94\%, 92\%); (e) (1) TsO $\left(\mathrm{CH}_{2} \mathrm{CH}_{2} \mathrm{O}\right)_{2} \mathrm{Bn}$ (37), $\mathrm{KOH}, \mathrm{THF}, \Delta$ and (2) TsOH, MeOH, RT (68\%, 73\%); (f) $\mathrm{BrCH}_{2} \mathrm{COOtert-Bu,} \mathrm{tert-}$ BuOK, tert-BuOH, RT (72\%, 78\%); (g) TFA, RT (97\%, 93\%); (h) Pd/C, $\mathrm{H}_{2}$, dioxane, RT (100\%, $\left.100 \%\right)$; (i) $\mathrm{CoCl} 2,250{ }^{\circ} \mathrm{C}, \mathrm{p} \approx 5$ $\mathrm{mmHg}(72 \%, 56 \%)$. The yields in parentheses refer to the isobutyl- and methyl-substituted compounds, respectively. DHP = 3,4-dihydro-2H-pyran; Ts = p-toluenesulfonyl; TFA = trifluoroacetic acid.

Scheme 2

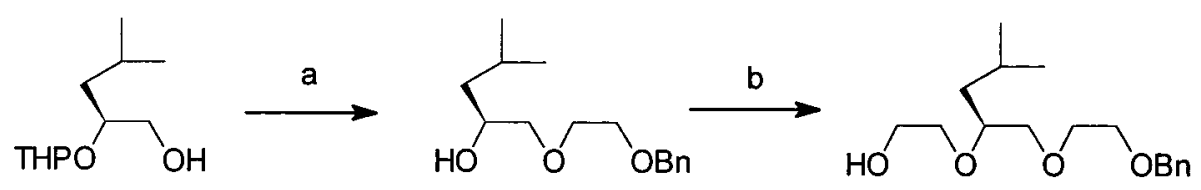

(S) -13

(S) -23

(S)-24

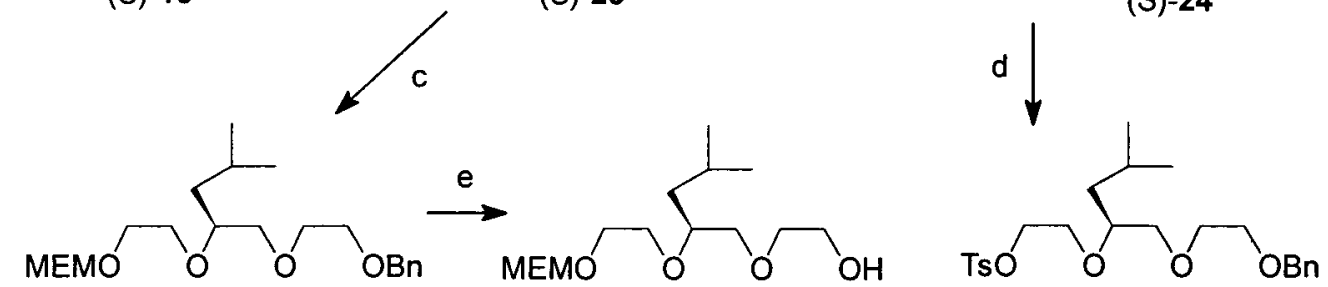

(S) -25

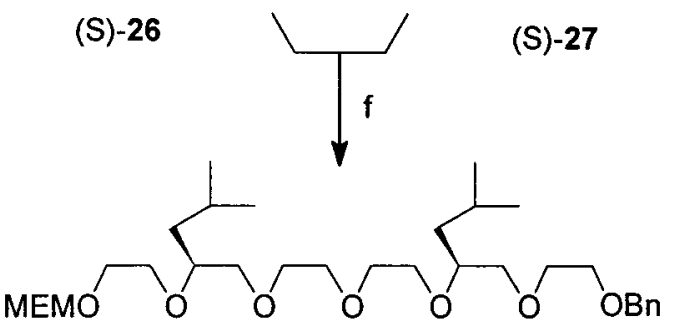

(SS)-28

(a) (1) $\mathrm{TsOCH}_{2} \mathrm{CH}_{2} \mathrm{OBn}$ (34), $\mathrm{KOH}, \mathrm{THF}, \Delta$ and (2) TsOH, MeOH, RT (77\%); (b) (1) THPOCH${ }_{2} \mathrm{CH}_{2} \mathrm{OTs}(35), \mathrm{KOH}, \mathrm{THF}, \Delta$ and (2) TsOH, $\mathrm{MeOH}, \mathrm{RT}(40 \%)$; (c) $\mathrm{MEMOCH}{ }_{2} \mathrm{CH}_{2} \mathrm{OTs}$ (36), $\mathrm{KOH}, \mathrm{THF}, \Delta(67 \%) ;\left(\right.$ d) TsCl, pyridine, $4{ }^{\circ} \mathrm{C}(90 \%) ;(\mathrm{e}) \mathrm{Pd} / \mathrm{C}, \mathrm{H}_{2}, \mathrm{MeOH}$, RT (91\%); (f) $\mathrm{KOH}, \mathrm{THF}, \Delta$ (68\%). Ts = p-toluenesulfonyl; MEM = methoxyethoxymethylene.

idine and $\mathrm{PPh}_{3}$. Subsequent column chromatography gave 2-oxo-21-crown-7 monomer (SS)-4 in a $50 \%$ yield.

The overall yields for the 13-step, 9-step, and 7-step syntheses of the 2-oxo crown ethers (SS)-4, (S)-5, and (S)-6 calculated from the starting materials leucine ((S)-
7) and ethyl lactate ((S)-10) are 2\%, 11\%, and 26\%, respectively. The crown ethers have been characterized by ${ }^{1} \mathrm{H} N M R,{ }^{13} \mathrm{C}$ NMR, GC-MS, and/or HRMS (highresolution mass spectrometry) techniques, FTIR, and CD-spectroscopy (the latter two characterization tech- 


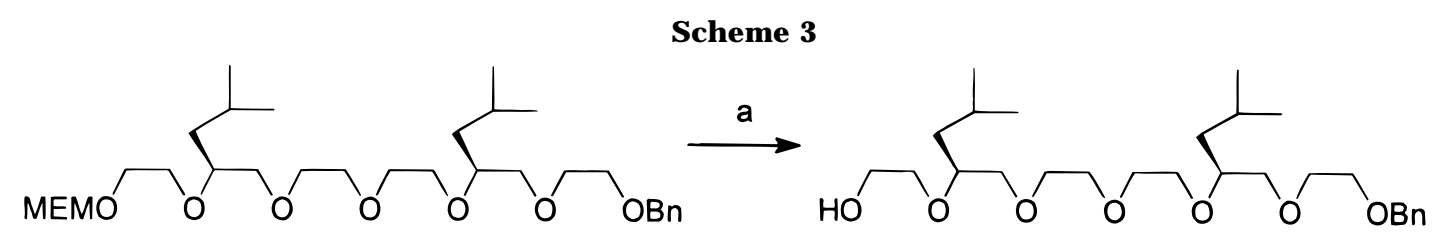

(SS)-28

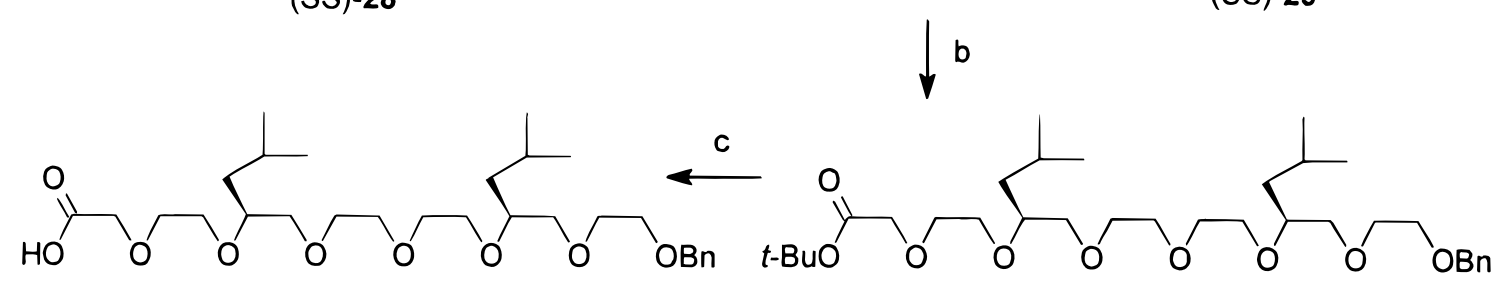

(SS)-31
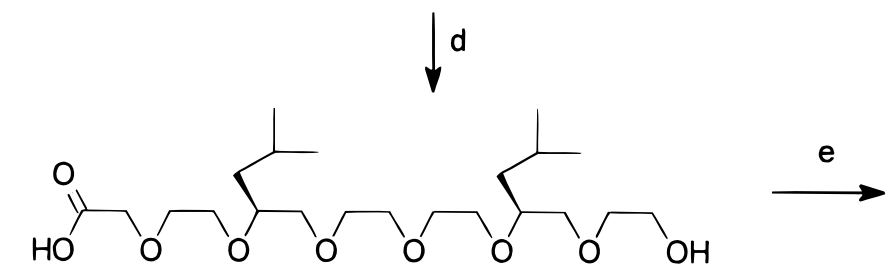

(SS)-32

(SS)-30

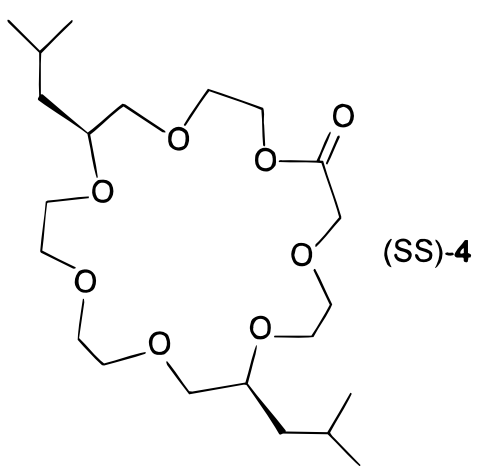

(a) $\mathrm{ZnBr}_{2}, \mathrm{CH}_{2} \mathrm{Cl}_{2}$, RT (44\%); (b) $\mathrm{BrCH}_{2} \mathrm{COOtert-Bu}$, tert-BuOK, tert-BuOH, RT (85\%); (c) TFA, RT (94\%); (d) Pd/C, $\mathrm{H}_{2}$, dioxane, $\mathrm{H}_{2} \mathrm{O}, \mathrm{RT}(100 \%)$; (e) dithiodipyridine, $\mathrm{PPh}_{3}$, xylene, RT (50\%).

niques have only been applied to the 2-oxo-12-crown-4 ethers). The collected data are in agreement with the assigned structures. As an example, the ${ }^{1} \mathrm{H}$ NMR and ${ }^{13} \mathrm{C}$ NMR spectra of (S)-5 are shown in Figure 3: the ${ }^{1} \mathrm{H}$ NMR spectrum is rather complex due to the chirality of the oxo-crown ether.

Several key compounds were investigated to ensure that the enantiomeric excesses of the starting compounds leucine ((S)-7) (ee = 97\%) and ethyl (S)-lactate ((S)-10) (ee > 99.5\%) were preserved in the final oxocrown ethers. ${ }^{17}$ First, ethyl leucate ((S)-9) was heated at reflux under esterification conditions for 1 week. Subsequent analysis of (S)-9 on a permethylated $\beta$-cyclodextrin GC-column did not reveal any signs of racemization. This result implies that not only the esterification to (S)-9 but also the preceding diazotation reaction to (S)-8 are not accompanied by significant racemization. ${ }^{18}$ Second, (2R)-1,2-propanediol was stirred overnight at $60{ }^{\circ} \mathrm{C}$ in dioxane in the presence of $\mathrm{KOH}$. After workup, the diol was analyzed on a permethylated $\beta$-cyclodextrin GC-column processed at $100{ }^{\circ} \mathrm{C}$. Comparison with the (S)-enantiomer indicated that no (partial) racemization had taken place, proving that the routinely applied reaction conditions for Williamson syntheses on chiral secondary alcohols do not lead to racemization. Finally, the 2-oxo crown ethers (S)-5 and (S)-6 could be analyzed on the-in this research very useful-permethylated $\beta$-cyclodextrin capillary GCcolumn. Assuming that the found contaminations correspond to the $(\mathrm{R})$-enantiomers, expected enantiomeric excesses of ca. $97 \%$ and ca. $99.5 \%$ were measured for (S)-5 and (S)-6, respectively. ${ }^{19}$

Preparation of Polymers 1-3. The desired polymers 1-3 could be obtained either by ring-opening polymerization of oxo-crown ethers (SS)-4, (S)-5, and (S)-6 or by polycondensation of the $\omega$-hydroxycarboxylic acids (S)-32, (S)-21, and (S)-22. All ring opening polymerizations were executed employing stannous 2-ethyl hexanoate $\left(\mathrm{SnOct}_{2}\right)$ as catalyst, applying catalyst/ monomer molar ratios ( $\mathrm{SnOct}_{2} / \mathrm{M}$ ) higher than 1/60, and using a polymerization temperature of $130{ }^{\circ} \mathrm{C}$. A previous study has shown that these conditions can conveniently be applied to the $\mathrm{SnOct}_{2}$-catalyzed ringopening polymerization of 2-oxo-12-crown-4. ${ }^{12 a}$ The polycondensations were performed both with and without the use of a Lewis acid catalyst ( $\mathrm{SnOct}_{2}$ was also in these cases chosen as the catalyst). Additionally, lipasecatalyzed polycondensation of monomers (S)-21 and (S)$\mathbf{2 2}$ was attempted; in both cases no polymeric material could be obtained (in contrast, successful lipase-mediated polycondensations have been reported for $\omega$-hydroxyalkanoic acids 20 ). The results of all successful polymerizations, including some reference polymerizations of the nonsubstituted monomers 2-oxo-21-crown-7 and 2-oxo-12-crown-4, ${ }^{21}$ have been summarized in Table 1 .

All polymerizations were carried out without solvent. Thering-opening polymerizations were conducted under an argon atmosphere, whereas the polycondensations were performed at reduced pressures (to remove the $\mathrm{H}_{2} \mathrm{O}$ that is liberated during reaction). The application of the $\mathrm{SnOct}_{2}$ catalyst in the polycondensations could markedly reduce the polycondensation temperaturecompare entries $\mathrm{C}$ and $\mathrm{D}, \mathrm{H}$ and $\mathrm{I}$, and $\mathrm{M}$ and $\mathrm{N}$. After reaction times of typically hours-only the ring-opening reactions of the larger 2-oxo-21-crown-7 monomers require reaction times of days (entries $B$ and $L$ )-the reaction mixtures were dissolved in minimum amounts of $\mathrm{CH}_{2} \mathrm{Cl}_{2}$ and precipitated in hexane or hexane/Et $\mathrm{t}_{2} \mathrm{O}$ solvent mixtures to yield the polymers as yellowish, sticky oils. The number average molecular weights $\left(M_{n}\right)$ 

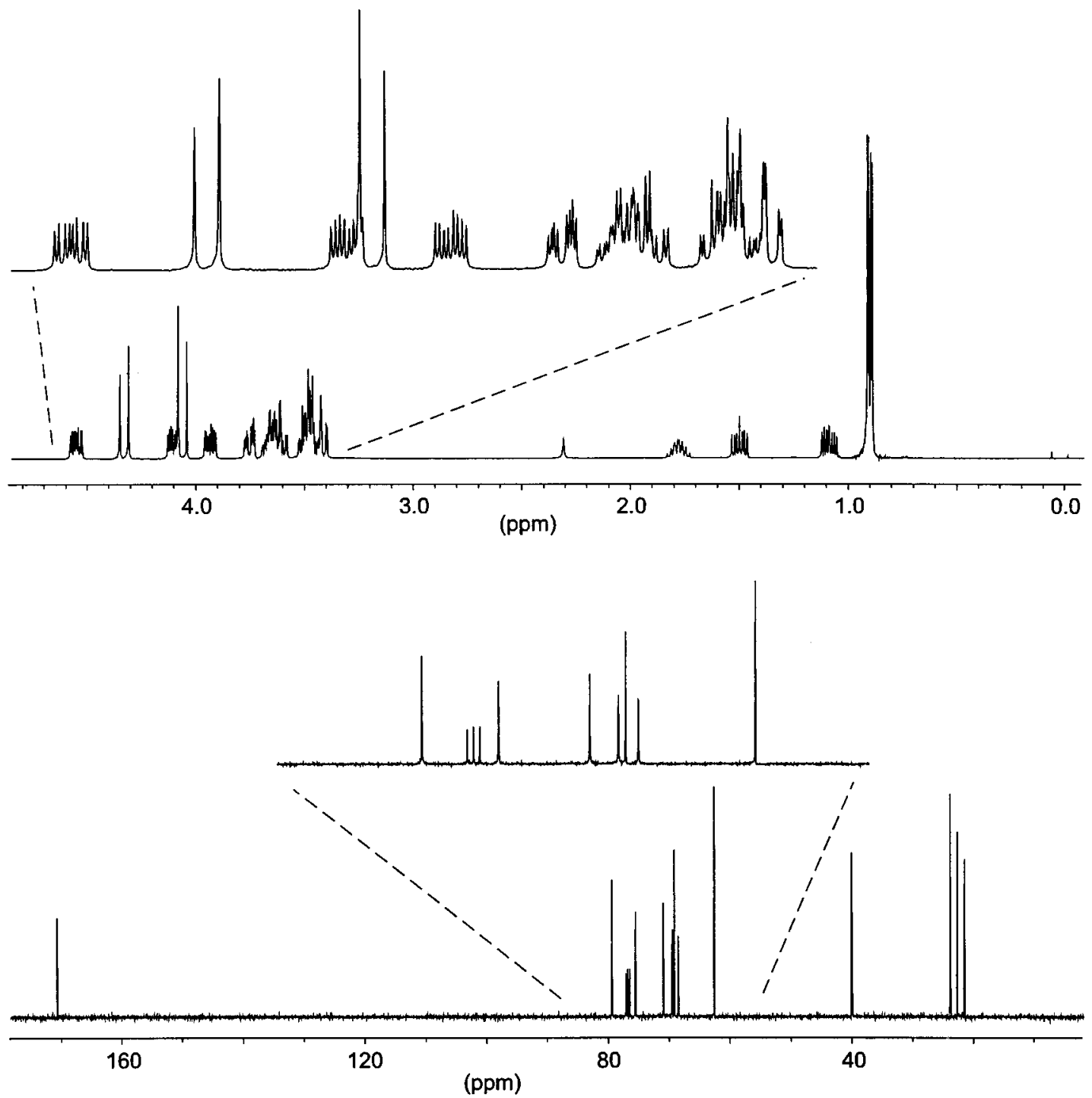

Figure 3. ${ }^{1} \mathrm{H}$ NMR spectrum (upper graph with expansion) and ${ }^{13} \mathrm{C}$ NMR spectrum (lower graph with expansion) of 2-oxo-5(S)-isobutyl-12-crown-4 ((S)-5) in $\mathrm{CDCl}_{3}$.

Table 1. Polymerization Conditions

\begin{tabular}{|c|c|c|c|c|c|c|}
\hline polymer & $\begin{array}{c}\text { procedure, } \\
\text { polymerization type }\end{array}$ & $\begin{array}{l}\mathrm{SnOct}_{2} / \mathrm{M} \\
\text { molar ratio }\end{array}$ & $\begin{array}{c}\mathrm{T} \\
\left({ }^{\circ} \mathrm{C}\right)\end{array}$ & $\begin{array}{c}\mathrm{t} \\
(\mathrm{h})\end{array}$ & $\begin{array}{c}\mathrm{M}_{\mathrm{n}^{\mathrm{a}}} \\
(\mathrm{kg} / \mathrm{mol})\end{array}$ & $D^{a}$ \\
\hline \multirow[t]{2}{*}{1} & A, polycondensation & $1 / 37$ & 140 & 7 & $3.5^{*}$ & $2.1^{*}$ \\
\hline & $B$, ring opening & $1 / 20$ & 130 & 100 & 5.2 & 1.7 \\
\hline \multirow[t]{5}{*}{2} & C, polycondensation & 0 & 200 & 5 & 4.3/3.0* & 2.0/2.0* \\
\hline & $\mathrm{D}$, polycondensation & $1 / 30$ & 135 & 5 & $4.0^{*}$ & $1.7^{*}$ \\
\hline & E, ring opening & $1 / 56$ & 130 & 20 & 2.6 & 2.2 \\
\hline & $F$, ring opening & $1 / 23$ & 130 & 24 & 7.4/4.6* & 2.0/1.9* \\
\hline & $\mathrm{G}$, ring opening & $1 / 16$ & 130 & 20 & 7.9 & 2.4 \\
\hline \multirow[t]{4}{*}{3} & $\mathrm{H}$, polycondensation & 0 & 200 & 8 & 3.2 & 2.0 \\
\hline & I, polycondensation & $1 / 45$ & 140 & 4 & $3.5^{*}$ & $2.4^{*}$ \\
\hline & $\mathrm{J}$, ring opening & $1 / 23$ & 130 & 20 & 4.1 & 2.0 \\
\hline & $\mathrm{K}$, ring opening & $1 / 24$ & 130 & 20 & $14.9 / 9.1^{*}$ & $2.1 / 2.1^{*}$ \\
\hline poly(2-oxo-21-crown-7) & $\mathrm{L}$ - ring opening & $1 / 25$ & 130 & 144 & 11.4 & 1.9 \\
\hline \multirow[t]{3}{*}{ poly(2-oxo-12-crown-4) } & M - polycondensation & 0 & 215 & 8 & 11.0/7.7* & $2.2 / 2.1^{*}$ \\
\hline & $\mathrm{N}$ - polycondensation & $1 / 38$ & 130 & 6 & $2.6^{*}$ & $1.8^{*}$ \\
\hline & O - ring opening & $1 / 50$ & 130 & 20 & 9.0 & 1.9 \\
\hline
\end{tabular}

a The number average molecular weights $\left(\mathrm{M}_{\mathrm{n}}\right.$ 's) and molecular weight distributions (D's) were obtained by SEC using polystyrene (PS) standards, except in those entries indicated with an asterix $(*)$ in which polyethylene oxide (PEO) standards were used. The measured $\mathrm{M}_{\mathrm{n}}$ is approximately $30-40 \%$ lower when PEO standards are used.

of the polymers varied between 2 and $15 \mathrm{~kg} / \mathrm{mol}$, and the measured dispersities (D) were always approximately 2. Unfortunately, the molecular weight of the polymers could not be tuned with the applied reaction conditions, probably due to the small scale on which the polymerizations were performed. On the basis of the results shown in Table 1 , there is no pronounced preference for a certain polymerization procedure, although the noncatalyzed polycondensations require harsher reaction conditions and the ring-opening polymerizations require longer reaction times, especially in the cases of the larger 2-oxo-21-crown-7 monomers. 

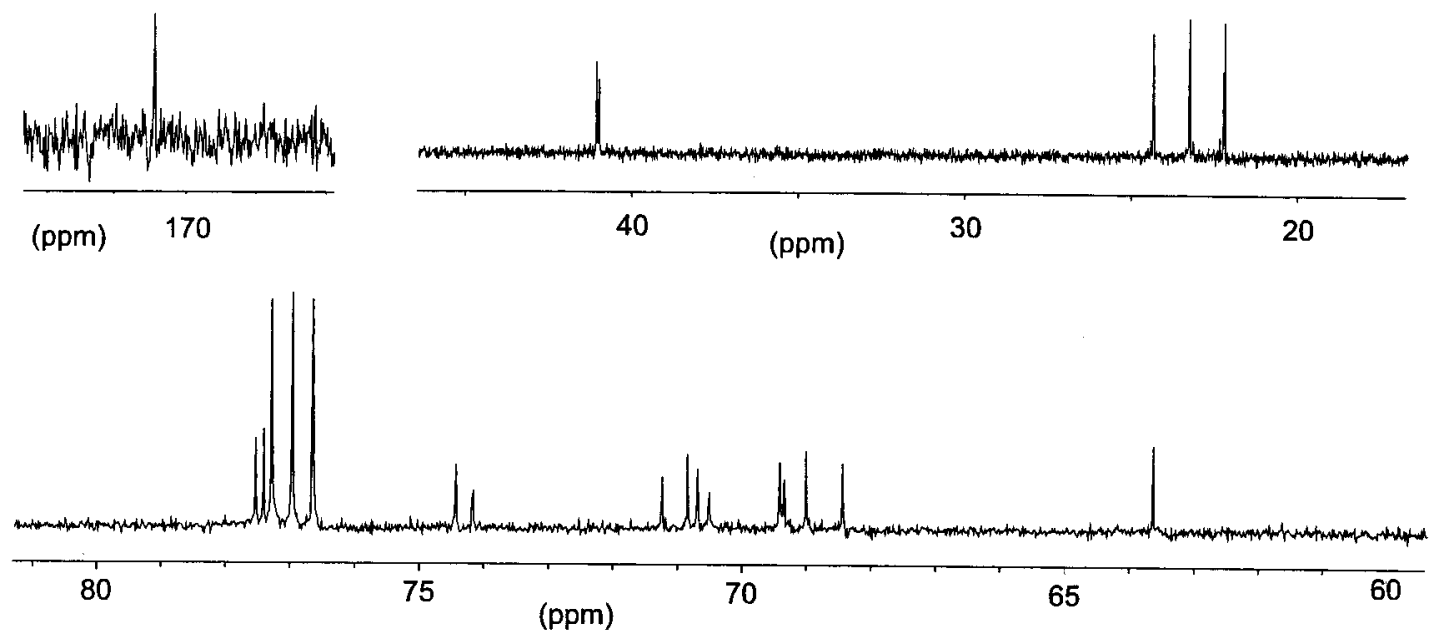

Figure 4. ${ }^{13} \mathrm{C}$ NMR spectrum of polymer 1 in $\mathrm{CDCl}_{3}$ : upper left, the carbonyl signal (one carbon atom); upper right, the carbon signals of the isobutyl side groups ( $4 \times 2=8$ carbon atoms); bottom: all carbon signals associated with the backbone ethylene oxide fragments (13 carbon atoms).

NMR Analysis of Polymers 1-3. The ${ }^{1} \mathrm{H}$ NMR and ${ }^{13} \mathrm{C}$ NMR spectra of the polymers $\mathbf{1}-\mathbf{3}$ suggest that polymerization is not accompanied by significant degradation or side reactions. As an example the ${ }^{13} \mathrm{C} N \mathrm{NR}$ spectrum of polymer $\mathbf{1}$ is shown in Figure 4: the spectrum accounts for no more than the expected 22 carbons. Molecular weights of the polymers could not be determined by ${ }^{1} \mathrm{H} N M R$, since the end group protons could not be detected separately.

ES-MS Characterization of Polymers 1-3. Electrospray mass spectrometry (ES-MS) facilitates the characterization of molecules with masses up to 500000 $\mathrm{Da}$, explaining its importance in the study of proteins. ${ }^{22}$ ES-MS is a mild technique, since it allows pre-existing ions in solution to be transferred to the gas phase with minimum fragmentation. Depending on the mode of measurement, the mass/charge ratio $(\mathrm{m} / \mathrm{z})$ of anions or cations can be measured. Polymers $\mathbf{1}-\mathbf{3}$ can ideally be characterized in the negative ion mode, since $\mathbf{1 - 3}$ are macromolecules with a carboxylic end group. Under neutral or basic conditions, the carboxylic acid end groups will be deprotonated and one macromolecule will bear exactly one negative charge. Consequently, $\mathrm{m} / \mathrm{z}$ values equal to the molecular weight of the polymeric species minus one will be measured. Polymers 1-3 were analyzed in aqueous mixtures of $\mathrm{MeCN}$, to which $\mathrm{CH}_{3} \mathrm{COONH}_{4}$ Crystals were added to assure deprotonation of the carboxylic end group.

In Figure 5, four ES-MS spectra of polymers 1, 2, 3, and poly(2-oxo-12-crown-4) are shown. It can be seen that only discrete mol ecular weights are measured. The molecular weights of the repeating units of $\mathbf{1}, \mathbf{2}, \mathbf{3}$, and poly(2-oxo-12-crown-4) are 434, 246, 204, and $190 \mathrm{Da}$, respectively, and therefore, the measured discrete values correspond to the deprotonated oligomeric species of the investigated polymers. Thus, these ES-MS results prove the integrity of the synthetic procedure that has been used to obtain polymers 1-3. In particular, it shows that during polymerization no significant degradation, leading to the disruption of the regular repeat of the polar and apolar segments in the polymers, has occurred.

It must be noted that the ES-MS data show a molecular weight distribution different from the distribution determined by SEC (see Table 1). This difference is caused by a lower sensitivity of higher molecular weight species for detection in the negative ion ES-MS mode. ${ }^{23}$ Apparently, ES-MS does not characterize the bulk of the material under investigation. This assumption also explains the detection of TFA adducts in the ES-MS characterization of polymer $\mathbf{2}$ (see Figure 5B); possibly these adducts are sensitive toward detection.

Polymers 1-3: A New Class of Amphiphilic Polymers. The behavior of polymers $\mathbf{1}-\mathbf{3}$ was studied in $\mathrm{H}_{2} \mathrm{O}$ to investigate the amphiphilic properties of these polymers. In $\mathrm{H}_{2} \mathrm{O}$, transparent solutions were only observed at low concentrations $(<0.1,<0.3$, and $<1.0$ $\mathrm{mg} / \mathrm{mL}$, for polymers $\mathbf{1}, \mathbf{2}$, and $\mathbf{3}$, respectively). At higher concentrations of $1-10 \mathrm{mg} / \mathrm{mL}$, stable turbid solutions were obtained. ${ }^{24}$ Turbid solutions of polymer $\mathbf{1}$ and $\mathbf{3}$ in $\mathrm{H}_{2} \mathrm{O}$ were investigated with dynamic light scattering (DLS). Aggregates with diameters of ca. 300 and ca. $200 \mathrm{~nm}$ were found for solutions of $\mathbf{1}$ and $\mathbf{3}$, respectively. ${ }^{25}$ The observed behavior of $\mathbf{1}-\mathbf{3}$ is reminiscent of the behavior of amphiphilic polymers in $\mathrm{H}_{2} \mathrm{O}$, so further examination of these systems was conducted.

A fluorescent-probe study is a simple and effective way to measure the critical aggregation concentration (cac) of amphiphilic compounds or polymers.26,27 The basis for such a study is the dependence of the fluorescent behavior of an apolar probe on the polarity of the environment of this probe. A widely applied probe is pyrene. For the polymers discussed here, it was found that the maximum in the excitation spectrum of pyrene shifted from 335 to $338 \mathrm{~nm}$ upon association. Thus, I $\mathrm{I}_{338}$ $I_{335}$ is a measure for the presence of polymer aggregates. These measures for aggregation-i.e. $I_{338} / I_{335}$ and $I_{3} / I_{1}$ in the exitation and emission spectra of pyrene, respectively-are comparable to previously reported measures for aggregation. ${ }^{27}$ In the emission spectrum, such a measure could be found in the $I_{3} / l_{1}$-ratio: the ratio between the third and first vibronic bands in the emission spectrum $\left(I_{\lambda}=\right.$ intensity of fluorescence at wavel ength $\lambda$ ).

Aqueous solutions with increasing concentrations of polymers 1-3, poly(2-oxo-12-crown-4), and PEO were investigated with the fluorescent-probe technique using pyrene as the probe. ${ }^{28}$ Additionally, the turbidity of the solutions was measured by determination of the absorbance of these solutions at $700 \mathrm{~nm}$. All measurements were conducted at $20^{\circ} \mathrm{C}$, and the results of the experiments are summarized in Figure 6. A clear picture emerges: three regimes can be observed. In the first regime-at low concentrations of polymer-no aggre- 


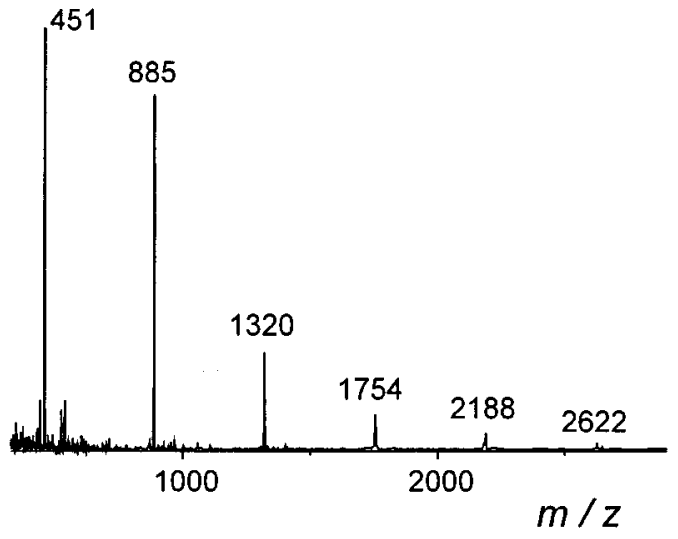

A

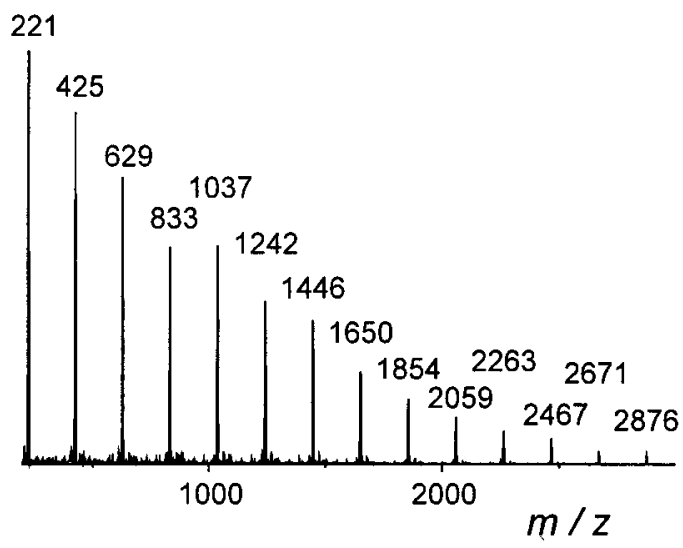

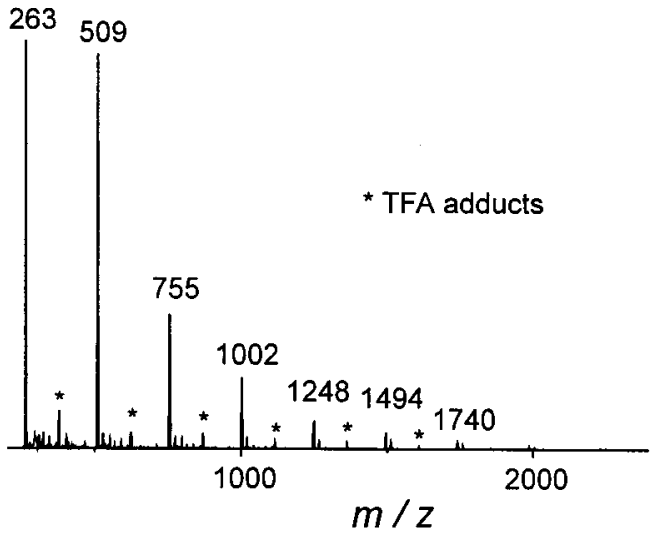

B

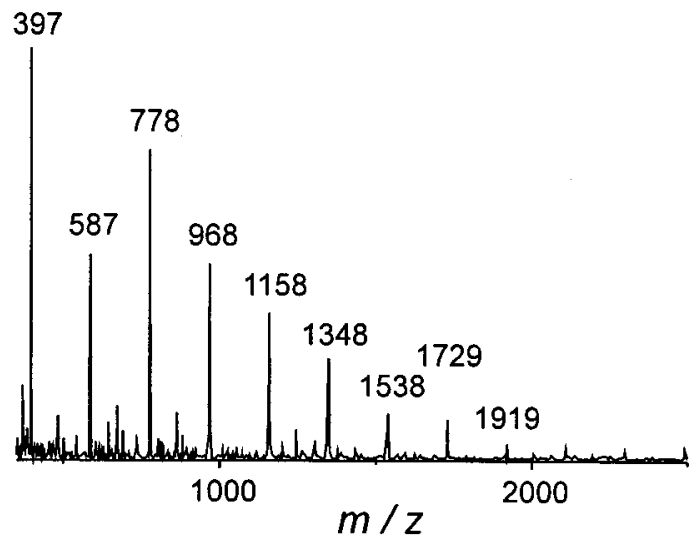

C

Figure 5. ES-MS spectra of polymers 1, 2, and $\mathbf{3}$ and poly(2-oxo-12-crown-4) in parts A, B, C, and D, respectively. ${ }^{40}$ The observed molecular weight/charge ratios $(\mathrm{m} / \mathrm{z}$ ) of the oligomeric species obey the formula $\mathrm{m} / \mathrm{z}=\mathrm{n} \cdot \mathrm{FW}$ (monomeric unit) $+\mathrm{FW}$ (water) -1 , with $\mathrm{FW}$ (monomeric unit) $=434,246,204$, and 190 for 1, 2, 3, and poly(2-oxo-12-crown-4), respectively. The y-axes have arbitrary units.

gates of polymer chains exist. This situation changes at the cac of the polymer (the onset of the change in $\mathrm{I}_{338} / \mathrm{I}_{335}$ or $\mathrm{I}_{3} / \mathrm{I}_{1}$ ratio). Aggregate formation begins, but the aqueous solutions remain transparent (regime 2). Further increase of the polymer concentration gives the formation of stable turbid solutions, which is the characteristic of regime 3 (in the case of poly(2-oxo-12crown-4) and PEO this third regime is not observed, because the aqueous solutions remain transparent).

A different cac value was determined for every polymer under investigation (see Table 2, in which all measured cac values have been collected). For polymers 1-3, poly(2-oxo-12-crown-4), and PEO, cac's of $2.1 \times$ $10^{-3}, 1.3 \times 10^{-2}, 0.15,0.62$, and $1.5 \mathrm{mg} / \mathrm{mL}$ were measured. The introduction of hydrophobic segments in a hydrophilic sequence gives polymers with an increased impetus for aggregate formation, as is evident from comparison of the cac values of polymers 1-3 with those found for poly(2-oxo-12-crown-4) and PEO. Focusing on the calculated average cac's, it is clear that the cac can be tailored by (i) the frequency at which the alkyl side groups of the polymers repeat and (ii) the size of these alkyl side groups. A slight reduction in the frequency of the repeat of isobutyl groups-compare polymers $\mathbf{1}$ and $\mathbf{2}$-results in a sixfold increase of the cac. Replacement of the isobutyl side groups by methyl side groups-compare polymers 2 and 3-gives an approximate tenfold increase in the cac. Finally, the influence of molecular weight on the cac value was not noticeable. Comparison of the cac's of two batches of polymer 2 with molecular weights of 4.3 and $2.6 \mathrm{~kg} / \mathrm{mol}$, respectively (entries $C$ and $E$ in Table 1 ), does not show a significant difference in the cac's (see Table 2 ).

It must be noted that the accuracy of the measured cac values is low: the distribution in the collected data is high, so an error in the average cac of $50 \%$ is realistic. However, such an error is inherent to the determination of cac's. ${ }^{26}$ Moreover, the size of this error is not dramatic, because the differences between the cac's of the investigated polymers are an order of a magnitude larger.

It is interesting to compare the new amphiphilic polymers 1-3 to the amphiphilic PEO/PPO/PEO block copolymers, which are-chemically and in terms of molecular weight-similar. Alexandridis ${ }^{29}$ has determined the cac's of these block copolymers, varying the block sizes of both the PPO and the PEO block (see Table 3). It can be seen that the cac values of PEO/ PPO/PEO copolymers are consi derably higher than the cac values obtained for 1-3. A parallel between both amphiphilic systems is the possibility to adjust the cac value by changing the constitution of the polymer. However, in the case of polymers 1-3, CAC-values can be obtained over a much wider concentration range (compare the fifth columns of Tables 2 and 3).

Another characteristic of PEO/PPO/PEO block copolymers is the formation of cubic, hexagonal, and lamellar (meso)phases in $\mathrm{p}$-xylene/ $\mathrm{H}_{2} \mathrm{O}$ solvent mixtures. Such phases are observed when the solvents are present in only a few weight percent. ${ }^{30}$ In a preliminary study, 


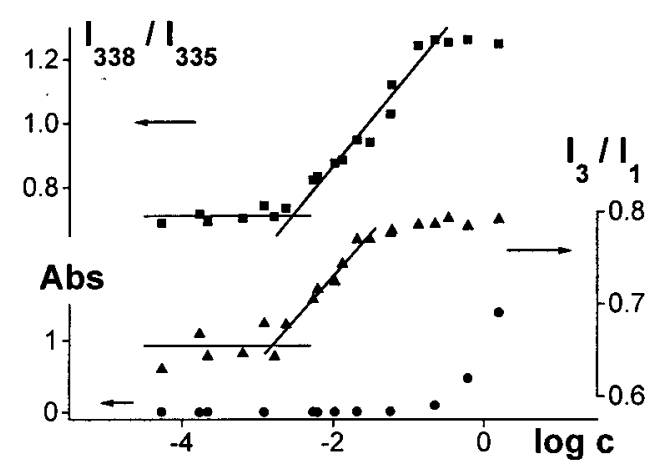

A

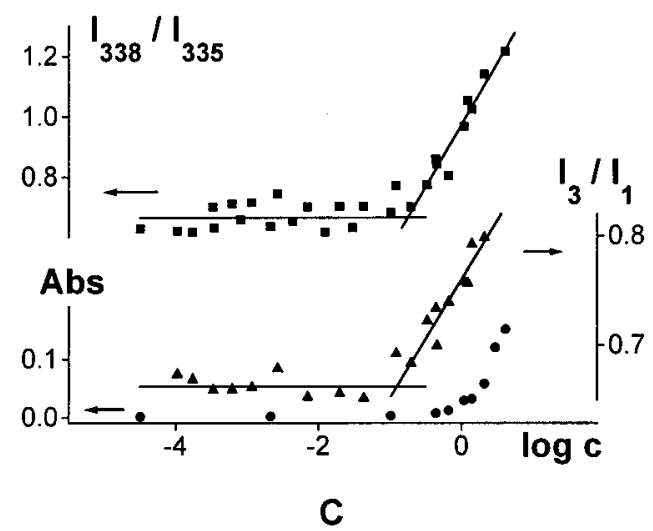

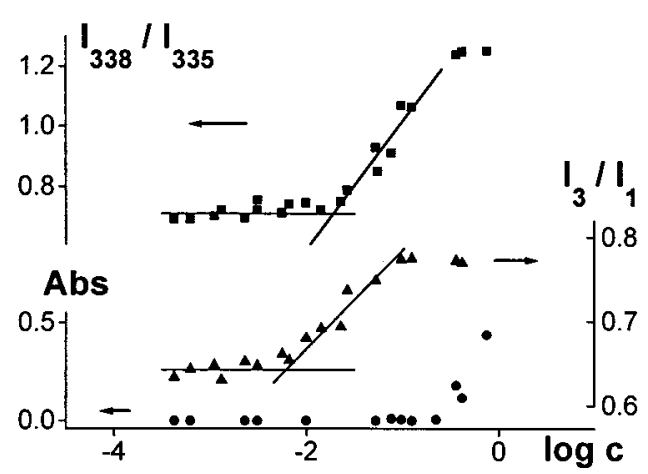

B

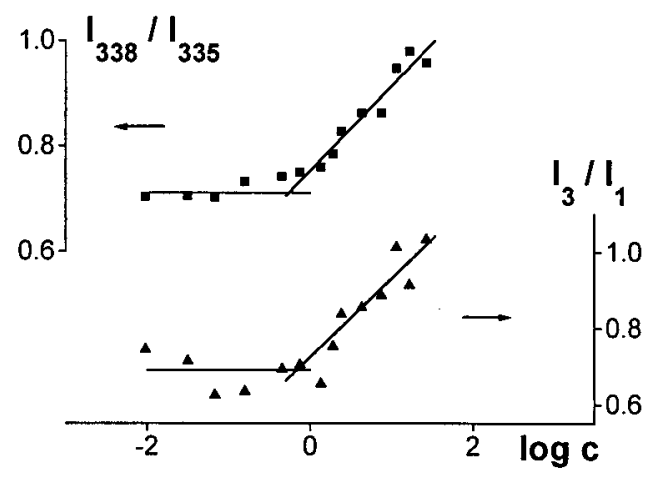

D

Figure 6. Fluorescent-probe studies on aqueous solutions of polymers $\mathbf{1}-\mathbf{3}$ and poly(2-oxo-12-crown-4). Shown are excitation

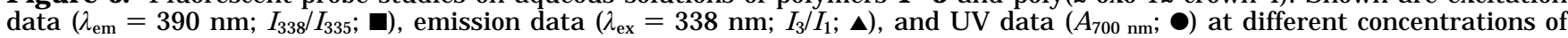
polymer in $\mathrm{H}_{2} \mathrm{O}$ at $20^{\circ} \mathrm{C}$. The concentration $(\log \mathrm{C})$ is calculated in milligrams per milliliter. The results concerning polymers $\mathbf{1}-\mathbf{3}$ and poly(2-oxo-12-crown-4) are shown in parts A, B, C, and D, respectively. A pyrene concentration of $4.1 \times 10^{-7} \mathrm{M}$ has been used for all data points.

Table 2. Critical Aggregation Concentrations (cac's) of Polymers in $\mathrm{H}_{2} \mathrm{O}$ at $20^{\circ} \mathrm{Ca}$

\begin{tabular}{|c|c|c|c|c|c|}
\hline polymer (entry) ${ }^{\mathrm{b}}$ & $\begin{array}{c}M_{n^{c}} \\
(\mathrm{~kg} / \mathrm{mol})\end{array}$ & $\begin{array}{l}\text { log cacem } \\
(\mathrm{mg} / \mathrm{mL})\end{array}$ & $\begin{array}{l}\log \mathrm{cac}_{\mathrm{ex}} \\
(\mathrm{mg} / \mathrm{mL})\end{array}$ & $\begin{array}{l}\mathrm{CAC}_{\mathrm{av}}{ }^{\mathrm{d}} \\
(\mathrm{mg} / \mathrm{mL})\end{array}$ & $\begin{array}{l}\text { onset turbidity } \\
\qquad(\mathrm{mg} / \mathrm{mL})\end{array}$ \\
\hline $\begin{array}{l}\mathbf{1}(\mathrm{A}) \\
\mathbf{2}(\mathrm{C})^{\mathrm{e}} \\
(\mathrm{E}) \\
\mathbf{3}(\mathrm{I}) \\
\text { poly(2-oxo-12-crown-4) (N) } \\
\text { PEO }^{f}\end{array}$ & $\begin{array}{l}3.5^{*} \\
4.3 \\
2.6 \\
3.5^{*} \\
2.6^{*} \\
8.0\end{array}$ & $\begin{array}{l}-2.81 \\
-2.00 \\
-2.21 \\
-0.91 \\
-0.16 \\
g\end{array}$ & $\begin{array}{r}-2.53 \\
-1.67 \\
-1.72 \\
-0.75 \\
-0.26 \\
0.18\end{array}$ & $\begin{array}{l}2.1 \times 10^{-3} \\
1.5 \times 10^{-2} \\
1.1 \times 10^{-2} \\
1.5 \times 10^{-1} \\
0.62 \\
1.5\end{array}$ & $\begin{array}{l}\approx 0.1 \\
\approx 0.3 \\
\approx 1.0 \\
\mathrm{~h} \\
\mathrm{~h}\end{array}$ \\
\hline
\end{tabular}

a Determined by fluorescence measurements using pyrene as probe: cac's have been derived from both emission and excitation spectra of pyrene at various concentrations of polymer. Applied pyrene concentration: $4.1 \times 10^{-7} \mathrm{M}$. E mission spectra: $\lambda_{\mathrm{ex}}=338 \mathrm{~nm}$. Excitation spectra: $\lambda_{\mathrm{em}}=390 \mathrm{~nm}$. Absorption measurements at $700 \mathrm{~nm}$ produced the turbidity-data. ${ }^{\mathrm{b}}$ The entry character defines which polymer batch has been used and it refers to the entries in Table 1. c Measured by SEC: PS standards or PEO standards (*) were used. d The average cac was calculated by taking the average of log cacem and log cacex (these are the cac's derived from the emission and the excitation spectra, respectively). e Here, a pyrene concentration of $1.2 \times 10^{-7} \mathrm{M}$ and a $\lambda_{\text {ex }}$ of $339 \mathrm{~nm}$ were applied. ${ }^{\mathrm{f}}$ Purchased from Sigma Chemicals (Article No. P-2139). ${ }^{9}$ No clear onset was visible. ${ }^{\mathrm{h}}$ The solutions did not become turbid at higher concentrations.

$\begin{gathered}\text { Table 3. Critical Aggregation Concentration Values of } \\
\text { PEO/PPO/PEO block copolymers in } \mathbf{H}_{\mathbf{2}} \mathbf{O} \text { at } \mathbf{2 0}{ }^{\circ} \mathbf{C}^{\mathbf{a}}\end{gathered}$
\begin{tabular}{ccccc}
$\mathrm{M}_{\mathrm{n}}$ & PO units in & EO units in & $\mathrm{cac}$ \\
polymerb & $(\mathrm{kg} / \mathrm{mol})$ & PPO-block & PEO blocks & $(\mathrm{mg} / \mathrm{mL})$ \\
\hline P103 & 5.0 & 60 & $2 \times 17$ & 7 \\
P104 & 5.9 & 61 & $2 \times 27$ & 20 \\
P105 & 6.5 & 56 & $2 \times 37$ & 22 \\
P123 & 5.8 & 69 & $2 \times 19$ & 1.8 \\
F127 & 12.6 & 65 & $2 \times 100$ & 40
\end{tabular}

a As determined by Alexandridis. ${ }^{29}$ 1,6-Diphenyl-1,3,5-hexatriene was used as the fluorescent probe. ${ }^{b}$ The investigated polymers were Pluronic copolymers purchased from BASF.

polymer $\mathbf{2}$ was investigated at $20^{\circ} \mathrm{C}$ under a microscope with crossed polarizers. ${ }^{31}$ Varying amounts of $p$-xylene and/or $\mathrm{H}_{2} \mathrm{O}$ were added to polymer 2, but no birefringence was observed. Consequently, the formation of hexagonal or lamellar phases could be excluded for this system.

Finally, the viscosities of aqueous solutions of polymers 1-3 were measured at concentrations both higher and lower than the determined cac. ${ }^{32}$ This was done to investigate whether aggregation would give a significant increase in viscosity, as for example observed for the so-called associative thickeners. ${ }^{27 b, 33}$ In the case of polymers 1-3, no such increase was measurable. In fact, for all solutions, the observed viscosities were equal to the viscosity of $\mathrm{H}_{2} \mathrm{O}$.

\section{Conclusion}

PE O-based polymers that possess a regular repeat of hydrophobically modified ethylene oxide units exhibit amphiphilic behavior in aqueous solutions. The first representatives of such PEO-based synthetic am- 
phiphilic polymers-polymers 1-3-have been introduced in this paper. With a fluorescent-probe study, the cac's (critical aggregation concentrations) of $\mathbf{1}-\mathbf{3}$ at $20{ }^{\circ} \mathrm{C}$ have been determined. Aggregation of the polymers was strongly promoted by the presence of the hydrophobic units, as was evident from a comparison of the cac's of 1-3 with the cac's of PEO and poly(2-oxo-12-crown-4): polymers lacking hydrophobic units. Additionally, the cac was dependent on both the size of the hydrophobic unit and the frequency at which such a unit was repeated in the polymer. It appears that tailoring of the cac of these amphiphilic polymers over a wide concentration range is possible (cac's of ca. $0.002 \mathrm{mg} / \mathrm{mL}$ and ca. $0.15 \mathrm{mg} / \mathrm{mL}$ were measured for 1 and 3, respectively).

The next paper will discuss the possibilities of the introduced polymers for the formation of well-defined higher structures. Optical rotatory dispersion (ORD) spectroscopy and transmission el ectron mi croscopy will be used to examine the ordering and assembly processes of polymers $\mathbf{1}-\mathbf{3}$ in aqueous solutions.

\section{Experimental Section}

General. Compounds (S)-8, (S)-9, (S)-11, (S)-12, (S)-13, (S)14, 34, and $\mathbf{3 7}$ have been described previously. . $^{9,10,11,14}$ For 34 and $\mathbf{3 7}$ new reaction routes have been used. Commercially available compounds employed in the syntheses were used without further purification, except tosyl chloride, which was recrystallized from hexane. The applied $\mathrm{KOH}$ had a purity > 85\%. The used solvents were dried if necessary: $\mathrm{Et}_{2} \mathrm{O}$ was dried on $\mathrm{CaCl}_{2}$ and stored on sodium wire. Dioxane was distilled from $\mathrm{LiAlH}_{4}, \mathrm{CH}_{2} \mathrm{Cl}_{2}$ from $\mathrm{CaH}_{2}$ or $\mathrm{P}_{2} \mathrm{O}_{5}$, pyridine from $\mathrm{KOH}$, and $\mathrm{PhMe}$ from $\mathrm{CaH}_{2}$; all were stored on activated molsieves (heated at $90{ }^{\circ} \mathrm{C}$ under vacuum for $24 \mathrm{~h}$ ). THF was immediately used after distillation from $\mathrm{Na}$.

Thin-layer chromatography (TLC) was performed on Merck 5735 Kieselgel 60F glass plates or on neutral type (type E) alumina $60 \mathrm{~F} 254$ (type E) aluminum plates. The TLC plates were air-dried, scrutinized under a UV lamp, and, if necessary, either sprayed with a p-anisaldehyde solution and developed using a heat gun or sprayed with an aqueous $\mathrm{KI} / \mathrm{I}_{2}$ solution. ${ }^{34}$ Kiesel gel 60 (0.040-0.063 mm mesh, Merck 9385), Merck flash silica gel 60 (particle size $0.040-0.063 \mathrm{~mm}$ ), or Merck alumina $(63-200 \mathrm{~mm})$ were used to perform col umn chromatography. A $25 \mathrm{~m}$ WCOT fused silica capillary column coated with a 0.25 mm thick CP Chirasil DEX CB (permethylated $\beta$-cyclodextrin) stationary phase was used to determine the optical purities of several compounds (the column was installed in a PE Auto System GC). Helium was used as carrier gas. The determination of the optical purity of L-leucine was achieved on a chiral Daicel CR (+) HPLC column (the measurement was carried out at DSM Research $\mathrm{Holland}$ ).

GC-MS was performed on a HP 5790 GC with an OV-1 column (a fused silica capillary column coated with a $0.33 \mathrm{~mm}$ thick poly(dimethylsiloxane) film) and an HP 5970A MSD. Size exclusion chromatography (SEC) analyses were conducted at $40{ }^{\circ} \mathrm{C}$ with stabilized THF as solvent and an eluent rate of 1 $\mathrm{mL} / \mathrm{min}$. The SEC apparatus was equipped with two Shodex KF 80-M (linear) col umns and a differential refractive index detector (Waters 410). Molecular weights were determined with polystyrene or polyethylene oxide calibration standards.

Elemental analyses were carried out on a PE 240. Differential scanning calometry measurements were performed on a PE DSC-2, applying two heating and cooling runs.

${ }^{1} \mathrm{H}-\mathrm{NMR}$ spectra were taken on an AM-400 Bruker spectrometer at $400 \mathrm{MHz}$ or on a Gemini Varian $300 \mathrm{MHz}$ spectrometer. TMS was used as internal standard. ${ }^{13} \mathrm{C}-\mathrm{NMR}$ spectra were taken on the Bruker spectrometer at $101 \mathrm{MHz}$ with the solvent as standard. In some cases, inverse-gated decoupled ${ }^{13} \mathrm{C}$ NMR was conducted to be able to integrate the carbon peaks. UV/vis measurements were performed on a PE UVN is Spectrophotometer Lambda 2B. Optical rotations were measured on a J ASCO DIP 370 digital polarimeter. CD spectra were taken on a J ASCO J -600 spectropolarimeter. Infrared spectra were taken on a Perkin Elmer 1605 FTIRspectrometer with wavenumbers between 4400 and $450 \mathrm{~cm}^{-1}$. Dynamic light scattering (DLS) measurements were conducted on a Malvern $4700 \mathrm{C}$ with a PCS-100 spectrometer $(\lambda=488$ $\mathrm{nm}$ ) at an angle of $90^{\circ}$ (spherical shaped aggregates were assumed).

ES-MS Measurements. Electrospray MS (ES-MS) was performed on a Perkin Elmer/Sciex API-300 MS/MS (PE-Sciex, Foster City). The compounds or polymers were dissolved in polar solvents or polar solvent mixtures (such as typically $\mathrm{MeCN} / \mathrm{H}_{2} \mathrm{O}$ ). Measurements were performed on solutions with concentrations of approximately $0.2 \mathrm{mg}$ of polymer $/ \mathrm{mL}$. A few crystals of $\mathrm{CH}_{3} \mathrm{COONH}_{4}$ were added to the aqueous solutions of the polymers to create a sufficiently basic medium for carboxylate formation. Care was taken that the solutions remained clear and did not phase separate.

Fluorescent-Probe Measurements. Fluorescence measurements were performed on a PE LS 50B luminescence spectrometer. The aqueous polymeric solutions that have been subjected to measurements were prepared as follows. Stock solutions of the polymers in $\mathrm{Me}_{2} \mathrm{CO}$ were weighed in precision flasks of $10 \mathrm{~mL}$ and to every flask $150 \mathrm{~mL}$ of a $2.7 \times 10^{-5} \mathrm{M}$ pyrene stock solution in $\mathrm{Me}_{2} \mathrm{CO}$ was added. The $\mathrm{Me}_{2} \mathrm{CO}$ was removed in vacuo at room temperature. Finally, $10 \mathrm{~mL}$ of $\mathrm{H}_{2} \mathrm{O}$ was added to each flask and the aqueous solutions were stirred for $15 \mathrm{~h}$ at $4{ }^{\circ} \mathrm{C}$. The flasks were wrapped in aluminum foil to prevent the pyrene from degrading. In the luminescence spectrometer, the cuvettes were kept at $20^{\circ} \mathrm{C}$ with a thermostat bath. For the excitation measurements, slits of 6 and 4 $\mathrm{nm}$ and, for the emission measurements, slits of 4.25 and 3 $\mathrm{nm}$ were used for the emission and excitation slits, respectively.

Poly(8(S),17(S)-diisobutyl-2-oxo-21-crown-7) (1). Procedure A: $\omega$-Hydroxycarboxylic acid (SS)-32 (210 mg, 0.46 $\mathrm{mmol}$ ) and $25 \mu \mathrm{L}$ of a $0.50 \mathrm{M} \mathrm{SnOct}_{2}$ solution in PhMe were transferred to a Schlenk flask (1/37 mol equiv of $\mathrm{SnOct}_{2}$ ). The mixture was stirred and was allowed to polymerize for $7 \mathrm{~h}$ at $140{ }^{\circ} \mathrm{C}$ and 0.04 mbar. Precipitation in hexane gave a viscous, yellowish, clear oil. Yield: $160 \mathrm{mg}(80 \%)$. SEC: $\mathrm{M}_{\mathrm{n}}=3.5 \mathrm{~kg} /$ mol, $\mathrm{D}=2.1$ (PEO standards). DSC: $\mathrm{T}_{g}=-44^{\circ} \mathrm{C}\left(\Delta \mathrm{C}_{\mathrm{p}}=\right.$ $\left.0.87 \mathrm{~J} \cdot \mathrm{g}^{-1} \cdot \mathrm{K}^{-1}\right)$.

Procedure B: 2-0xo-21-crown-7 ((SS)-4) $(23 \mathrm{mg}, 0.053$ $\mathrm{mmol}$ ) and $17 \mu \mathrm{L}$ of a $0.158 \mathrm{M} \mathrm{SnOct} 2$ solution in PhMe were transferred to a Schlenk flask ( $1 / 20$ catalyst/monomer ratio). The PhMe was evaporated at $30 \mathrm{mbar}$ and $40^{\circ} \mathrm{C}$. Thereafter, the mixture was stirred at $130^{\circ} \mathrm{C}$ under an argon atmosphere for 4 days. The sticky product was dissolved in a minimum amount of $\mathrm{CH}_{2} \mathrm{Cl}_{2}$ and precipitated in $5 \mathrm{~mL}$ of ice-cold hexane. A yellowish, clear, oily polymer (8 $\mathrm{mg}, 35 \%)$ was obtained. SEC: $M_{\mathrm{n}}=5.2 \mathrm{~kg} / \mathrm{mol}, \mathrm{D}=1.7$ (PS standards).

${ }^{1} \mathrm{H}-\mathrm{NMR}\left(400 \mathrm{MHz}, \mathrm{CDCl}_{3}, 25^{\circ} \mathrm{C}, \mathrm{TMS}\right): \delta=4.3(2 \mathrm{H}, \mathrm{m}$, $\left.\mathrm{CH}_{2} \mathrm{CH}_{2} \mathrm{CO}\right), 4.2\left(2 \mathrm{H}, \mathrm{s}, \mathrm{COCH}_{2} \mathrm{O}\right), 3.9-3.5(2 \mathrm{OH}, \mathrm{m}$, further backbone protons), $1.75\left(2 \mathrm{H}, \mathrm{m}, \mathrm{CH}_{2} \mathrm{CH}\left(\mathrm{CH}_{3}\right)_{2}\right), 1.45(2 \mathrm{H}, \mathrm{m}$, $\left.\mathrm{CH}^{\prime} \mathrm{H}^{\prime \prime} \mathrm{CH}\left(\mathrm{CH}_{3}\right)_{2}\right), 1.25\left(2 \mathrm{H}, \mathrm{m}, \mathrm{CH}^{\prime} \mathrm{H}^{\prime \prime} \mathrm{CH}\left(\mathrm{CH}_{3}\right)_{2}\right), 0.90(12 \mathrm{H}$ $\left.\mathrm{m}, 4 \times \mathrm{CH}_{3}\right) .{ }^{13} \mathrm{C}-\mathrm{NMR}\left(100 \mathrm{MHz}, \mathrm{CDCl}_{3}, 25^{\circ} \mathrm{C}\right): \delta=170.5$ (CO), 77.6, 77.5, 74.5, 74.2, 71.3, 70.9, 70.8, 70.6, 69.4(2), 69.1, 68.5, 63.7 (backbone carbons), 41.2, 41.1, 24.5(2), 23.3(2), 22.4, 22.3 (isobutyl carbons).

Poly(5(S)-isobutyl-2-oxo-12-crown-4) (2). Procedure C: $\omega$-Hydroxycarboxylic acid (S)-21 $(0.8 \mathrm{~g}, 3.03 \mathrm{mmol})$ was transferred to a flask and was rotated for $5 \mathrm{~h}$ in a Kugelrohr apparatus. The temperature was gradually raised to $200{ }^{\circ} \mathrm{C}$, and a vacuum of $0.1 \mathrm{mbar}$ was maintained. The obtained oil was precipitated from $\mathrm{CH}_{2} \mathrm{Cl}_{2}$ in hexane to give a viscous, yellowish, clear oil. Yield: $330 \mathrm{mg}(45 \%)$. SEC: $\mathrm{M}_{\mathrm{n}}=4.3 \mathrm{~kg} /$ $\mathrm{mol}, \mathrm{D}=2.0$ (PS standards); $M_{\mathrm{n}}=3.0 \mathrm{~kg} / \mathrm{mol}, \mathrm{D}=2.0$ (PEO standards).

Procedure D: $\omega$-Hydroxycarboxylic acid (S)-21 $(500 \mathrm{mg}$, $1.89 \mathrm{mmol}$ ) was transferred to a flask, and $125 \mu \mathrm{L}$ of a $0.50 \mathrm{M}$ $\mathrm{SnOct}_{2}$ solution in PhMe was added (1/30 mol equiv of $\mathrm{SnOct}_{2}$ ). The flask was rotated for $5 \mathrm{~h}$ in a Kugelrohr apparatus. The temperature was kept at $135^{\circ} \mathrm{C}$, and a vacuum of $0.6 \mathrm{mbar}$ was maintained. The obtained oil was precipitated from $\mathrm{CH}_{2-}$ $\mathrm{Cl}_{2}$ in hexane to afford a viscous, yellowish, clear oil. Yield: 
$340 \mathrm{mg}$ (73\%). SEC: $M_{n}=4.0 \mathrm{~kg} / \mathrm{mol}, \quad D=1.7$ (PEO standards). DSC: $\mathrm{T}_{\mathrm{g}}=-34^{\circ} \mathrm{C}\left(\Delta \mathrm{C}_{\mathrm{p}}=1.12 \mathrm{~J} \cdot \mathrm{g}^{-1} \cdot \mathrm{K}^{-1}\right)$.

Procedure E: Oxo-crown ether (S)-5 (310 mg, $1.26 \mathrm{mmol}$ ) and $45 \mu \mathrm{L}$ of a $0.50 \mathrm{M} \mathrm{SnOct}_{2}$ solution in PhMe were mixed in a Schlenk flask (56/1 monomer/catalyst ratio), after which the PhMe was removed by evaporation in vacuo. The mixture was stirred, and polymerization was carried out for $20 \mathrm{~h}$ at $130^{\circ} \mathrm{C}$ under an atmosphere of argon. Dissolution in a minimum amount of $\mathrm{CH}_{2} \mathrm{Cl}_{2}$ and precipitation in hexane/ $\mathrm{Et}_{2} \mathrm{O}(4 / 1)$ gave a yellowish, viscous oil. Yield: $210 \mathrm{mg}(68 \%)$. SEC: $\mathrm{M}_{\mathrm{n}}=$ $2.6 \mathrm{~kg} / \mathrm{mol}, \mathrm{D}=2.2$ (PS standards).

Procedure F : Oxo-crown ether (S)-5 (220 mg, $0.89 \mathrm{mmol}$ ) and $77 \mu \mathrm{L}$ of a $0.50 \mathrm{M} \mathrm{SnOct}_{2}$ solution in PhMe were mixed in a Schlenk flask (23/1 monomer/catalyst ratio), after which the PhMe was removed by evaporation in vacuo. The mixture was stirred, and polymerization was carried out for $24 \mathrm{~h}$ at $130^{\circ} \mathrm{C}$ under an atmosphere of argon. Dissolution in a minimum amount of $\mathrm{CH}_{2} \mathrm{Cl}_{2}$ and precipitation in hexane/Et $\mathrm{t}_{2} \mathrm{O}(4 / 1)$ gave a yellowish, viscous oil. Yield: $125 \mathrm{mg} \mathrm{(57 \% ).} \mathrm{SEC:} M_{n}=$ $7.4 \mathrm{~kg} / \mathrm{mol}, \mathrm{D}=2.0$ (PS standards); $M_{\mathrm{n}}=4.6 \mathrm{~kg} / \mathrm{mol}, \mathrm{D}=1.9$ (PEO standards).

Procedure G: Oxo-crown ether (S)-5 (100 mg, $0.41 \mathrm{mmol}$ ) and $50 \mu \mathrm{L}$ of a $0.50 \mathrm{M} \mathrm{SnOct} 2$ solution in $\mathrm{CH}_{2} \mathrm{Cl}_{2}$ were mixed in a Schlenk flask (16/1 monomer/catalyst ratio), after which the $\mathrm{CH}_{2} \mathrm{Cl}_{2}$ was removed by evaporation in vacuo. The mixture was stirred, and polymerization was carried out for $20 \mathrm{~h}$ at $130{ }^{\circ} \mathrm{C}$ under an atmosphere of argon. Dissolution in a minimum amount of $\mathrm{CH}_{2} \mathrm{Cl}_{2}$ and precipitation in hexane gave a yellowish, viscous oil. Yield: $80 \mathrm{mg}(80 \%)$. SEC: $\mathrm{M}_{\mathrm{n}}=7.9$ $\mathrm{kg} / \mathrm{mol}, \mathrm{D}=2.4$ (PS standards).

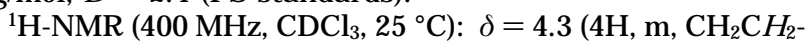
$\mathrm{CO}$ and $\left.\mathrm{COCH}_{2} \mathrm{O}\right), 3.7-3.4(9 \mathrm{H}, \mathrm{m}$, further backbone protons), $1.75\left(1 \mathrm{H}, \mathrm{m}, \mathrm{CH}_{2} \mathrm{CH}\left(\mathrm{CH}_{3}\right)_{2}\right), 1.4(1 \mathrm{H}, \mathrm{ddd}, 2 \mathrm{~J}=14.0 \mathrm{~Hz}, 3 \mathrm{~J}=$ $\left.8.5 \mathrm{~Hz},{ }^{3} \mathrm{~J}=5.9 \mathrm{~Hz}, \mathrm{CH}^{\prime} \mathrm{H}^{\prime \prime} \mathrm{CH}\left(\mathrm{CH}_{3}\right)_{2}\right), 1.25\left(1 \mathrm{H}, \mathrm{ddd},{ }^{2} \mathrm{~J}=14.0\right.$ $\left.\mathrm{Hz},{ }^{3} \mathrm{~J}=8.1 \mathrm{~Hz}, 3^{3}=4.8 \mathrm{~Hz}, \mathrm{CH}^{\prime} \mathrm{H}^{\prime \prime} \mathrm{CH}\left(\mathrm{CH}_{3}\right)_{2}\right), 0.9(6 \mathrm{H}$, dd, 3] $=7.0$ and $\left.6.6 \mathrm{~Hz}, \mathrm{CH}_{2} \mathrm{CH}\left(\mathrm{CH}_{3}\right)_{2}\right)$. ${ }^{13} \mathrm{C}-\mathrm{NMR}(100 \mathrm{MHz}$, $\left.\mathrm{CDCl}_{3}, 25^{\circ} \mathrm{C}\right): \delta=170.8(\mathrm{CO}), 78.0,75.0,70.6,70.4,69.0$, 67.7, 63.6 (backbone carbons), 40.9, 24.3, 23.2, 22.3 (isobutyl carbons).

Poly(5(S)-methyl-2-oxo-12-crown-4) (3). Procedure H: $\omega$-Hydroxycarboxylic acid (S)-22 (300 mg $1.36 \mathrm{mmol}$ ) was transferred to a flask, that was rotated for $8 \mathrm{~h}$ in a Kogelrohr apparatus. The temperature was gradually increased to 200 ${ }^{\circ} \mathrm{C}$, and a vacuum of $10 \mathrm{mmHg}$ was maintained. The obtained oil was precipitated from $\mathrm{CH}_{2} \mathrm{Cl}_{2}$ in $\mathrm{Et}_{2} \mathrm{O}$ /hexane (1/1) to give a viscous oil. The oil was dissolved in $\mathrm{MeCN}$, and active carbon was added. Filtration and evaporation gave $250 \mathrm{mg}$ (90\%) of a clear, viscous oil. SEC: $M_{n}=3.2 \mathrm{~kg} / \mathrm{mol}, \mathrm{D}=2.0$ (PS standards).

Procedure I: $\omega$-Hydroxycarboxylic acid (S)-22 (500 mg, 2.25 $\mathrm{mmol}$ ) and $100 \mu \mathrm{L}$ of a $0.50 \mathrm{M} \mathrm{SnOct}_{2}$ solution in PhMe were transferred to a Schlenk flask (1/45 mol equiv of SnOct 2 ). The mixture was stirred and was allowed to polymerize for $4 \mathrm{~h}$ at $140{ }^{\circ} \mathrm{C}$ and 0.03 mbar. Precipitation from $\mathrm{CH}_{2} \mathrm{Cl}_{2}$ in $\mathrm{Et}_{2} \mathrm{O} /$ hexane (5/1) gave a viscous, yellowish, clear oil. Yield: 330 mg (72\%). SEC: $M_{n}=3.5 \mathrm{~kg} / \mathrm{mol}, \mathrm{D}=2.4$ (PEO standards). DSC: $\mathrm{T}_{\mathrm{g}}=-39^{\circ} \mathrm{C}\left(\Delta \mathrm{C}_{\mathrm{p}}=0.85 \mathrm{~J} \cdot \mathrm{g}^{-1} \cdot \mathrm{K}^{-1}\right)$.

Procedure J : Oxo-crown ether (S)-6 (150 mg, $0.74 \mathrm{mmol}$ ) and $65 \mu \mathrm{L}$ of a $0.50 \mathrm{M} \mathrm{SnOct}_{2}$ solution in $\mathrm{CH}_{2} \mathrm{Cl}_{2}$ were mixed in a Schlenk flask (23/1 monomer/catalyst ratio). Then, the $\mathrm{CH}_{2} \mathrm{Cl}_{2}$ was removed by evaporation in vacuo. The mixture was stirred, and polymerization was carried out for $20 \mathrm{~h}$ at $130{ }^{\circ} \mathrm{C}$ under an atmosphere of argon. Dissolution in a minimum amount of $\mathrm{CH}_{2} \mathrm{Cl}_{2}$ and precipitation in hexane gave a yellowish, viscous, dear oil. Yield: $140 \mathrm{mg}(93 \%)$. SEC: $\mathrm{M}_{\mathrm{n}}$ $=4.1 \mathrm{~kg} / \mathrm{mol}, \mathrm{D}=2.0$ (PS standards).

Procedure K: Oxo-crown ether (S)-6 (240 mg, $1.18 \mathrm{mmol}$ ) and $100 \mu \mathrm{L}$ of a $0.50 \mathrm{M} \mathrm{SnOct}_{2}$ solution in PhMe were mixed in a Schlenk flask (24/1 monomer/catalyst ratio). Thereafter, the PhMe was removed by evaporation in vacuo. The mixture was stirred, and polymerization was carried out for $20 \mathrm{~h}$ at $130{ }^{\circ} \mathrm{C}$ under an atmosphere of argon. Dissolution in a minimum amount of $\mathrm{CH}_{2} \mathrm{Cl}_{2}$ and precipitation in hexane/ $\mathrm{E}_{2} \mathrm{O}$ (4/1) gave a yellowish, viscous, clear oil. Yield: $210 \mathrm{mg}$ (88\%). SEC: $M_{n}=9.1 \mathrm{~kg} / \mathrm{mol}, \mathrm{D}=2.1$ (PEO standards); $M_{\mathrm{n}}=14.9$ $\mathrm{kg} / \mathrm{mol}, \mathrm{D}=2.1$ (PS standards). ${ }^{1} \mathrm{H}-\mathrm{NMR}\left(400 \mathrm{MHz}^{\mathrm{C}} \mathrm{CDCl}_{3}\right.$, $\left.25{ }^{\circ} \mathrm{C}, \mathrm{TMS}\right): \delta=4.3\left(2 \mathrm{H}, \mathrm{m}, \mathrm{CH}_{2} \mathrm{CH}_{2} \mathrm{CO}\right), 4.25(2 \mathrm{H}, \mathrm{s}$, $\left.\mathrm{COCH}_{2} \mathrm{O}\right), 3.8-3.45(9 \mathrm{H}, \mathrm{m}$, further backbone protons), 1.2 $\left(3 \mathrm{H}, \mathrm{d}, 3 \mathrm{j}=6.6 \mathrm{~Hz}, \mathrm{CH}_{3}\right) .{ }^{13} \mathrm{C}-\mathrm{NMR}\left(100 \mathrm{MHz} \mathrm{CDCl}_{3}, 25\right.$ $\left.{ }^{\circ} \mathrm{C}\right): \delta=170.5$ (CO), 75.1(2), 70.3, 70.1, 68.6, 66.6, 63.3 (backbone carbons), 16.6 (methyl carbon).

Poly(2-oxo-21-crown-7). Procedure L: This procedure comprises the ring-opening polymerization of 2-oxo-21-crown-7 at $130{ }^{\circ} \mathrm{C}$ during $144 \mathrm{~h}$ using SnOct $_{2}$ as catalyst (25/1 monomer/catalyst ratio). SEC: $M_{n}=11.4 \mathrm{~kg} / \mathrm{mol}, D=1.9$ (PS standards). See ref 12 a for details on the monomer and the polymerization procedure.

Poly(2-oxo-12-crown-4). See ref 12a for details on the monomers and on the polymerization procedures.

Procedure M: [2-(2- $\{2-\mathrm{H}$ ydroxyethoxy $\}$-ethoxy)-ethoxy]acetic acid $(2.7 \mathrm{~g}, 13.0 \mathrm{mmol}$ ) was transferred to a flask, that was rotated in a Kugelrohr apparatus for $8 \mathrm{~h}$. The temperature was gradually raised to $215^{\circ} \mathrm{C}$, while a vacuum of 2 mbar was maintained. The residue was dissolved in a minimum amount of $\mathrm{CH}_{2} \mathrm{Cl}_{2}$ and precipitated in $\mathrm{Et}_{2} \mathrm{O}$. The polymer was obtained as a brown, sticky oil. Yield: $1.95 \mathrm{~g}(66 \%)$. SEC: $M_{n}=7.7$ $\mathrm{kg} / \mathrm{mol}, \mathrm{D}=2.1$ (PEO standards); $M_{\mathrm{n}}=11.0 \mathrm{~kg} / \mathrm{mol}, \mathrm{D}=2.2$

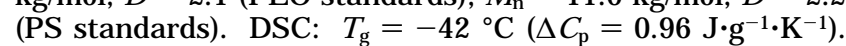

Procedure N: [2-(2- $\{2-\mathrm{H} y d r o x y e t h o x y\}$ ethoxy)ethoxy]acetic acid $\left(380 \mathrm{~g}, 1.83 \mathrm{mmol}\right.$ ) and $95 \mu \mathrm{L}$ of a $0.50 \mathrm{M} \mathrm{SnOct}_{2}$ solution in PhMe were transferred to a flask (38/1 monomer/catalyst ratio). The flask was rotated at $130^{\circ} \mathrm{C}$ for $6 \mathrm{~h}$. A vacuum of 10 mbar was maintained. The residue was dissolved in a minimum amount of $\mathrm{CH}_{2} \mathrm{Cl}_{2}$ and precipitated in $\mathrm{Et}_{2} \mathrm{O}$. The polymer was obtained as a yellowish, sticky oil. Yield: 280 $\mathrm{mg}(80 \%)$. SEC: $M_{\mathrm{n}}=2.6 \mathrm{~kg} / \mathrm{mol}, \mathrm{D}=1.8$ (PEO standards).

Procedure 0: This procedure comprises the ring-opening polymerization of 2-oxo-12-crown-4 at $130{ }^{\circ} \mathrm{C}$ during $20 \mathrm{~h}$ using $\mathrm{SnOct}_{2}$ as catalyst (50/1 monomer/catalyst ratio). SEC: $M_{n}$ $=9.0 \mathrm{~kg} / \mathrm{mol}, \mathrm{D}=1.9$ (PS standards).

(8S,17S)-2-0xo-8,17-diisobutyl-21-crown-7 ((SS)-4). $\alpha, \omega$ Dihydroxycarboxylic acid (SS)-32 (47 mg, $0.10 \mathrm{mmol})$ was dissolved in $3.5 \mathrm{~mL}$ of dry and oxygen-free xylene. $\mathrm{PPh}_{3}(40$ $\mathrm{mg}, 0.15 \mathrm{mmol}$ ) and dithiodipyridine ( $33 \mathrm{mg}, 0.15 \mathrm{mmol}$ ) were added, and the clear solution was stirred for 3 days (after 1 day the solution had become slightly turbid). The solvent was evaporated, and the residue was treated with hexane. Collection of the hexane phases and evaporation of the solvent gave a crude product that was purified by silica column chromatography. Subsequent elution with PhMe/EtOAc (4/ 1 ) and EtOAC gave $23 \mathrm{mg}(50 \%)$ of the title compound as an oil. ${ }^{1} \mathrm{H} \mathrm{NMR}\left(\mathrm{CDCl}_{3}\right): \delta=4.4(2 \mathrm{H}, \mathrm{m}), 4.25\left(2 \mathrm{H}, \mathrm{dd},{ }^{2} \mathrm{~J}=\right.$ $\left.16.9 \mathrm{~Hz}, \mathrm{OCH}_{2} \mathrm{COO}\right), 4.0-3.4(2 \mathrm{H}, \mathrm{m}), 1.75(2 \mathrm{H}, \mathrm{m}), 1.45(2 \mathrm{H}$, $\mathrm{m}), 1.15(2 \mathrm{H}, \mathrm{m}), 0.9(12 \mathrm{H}, \mathrm{d}, 3 \mathrm{~J}=6.6 \mathrm{~Hz}(4 \times)) .{ }^{13} \mathrm{C} \mathrm{NMR}$ $\left(\mathrm{CDCl}_{3}\right): \delta=170.9$ (CO), 40.9, 40.7, $24.5(2 \times), 23.3,23.2,22.4$, 22.2 (isobutyl carbons), 77.7, 77.5, 75.7, 75.4, 71.2, $71.0(2 \times)$, 70.5, 69.7, 69.6, 68.9, 68.4, and 63.8 (carbons of the ring). GCMS (FW = 434): $\mathrm{m} / \mathrm{z} 434$ and 435.

(5S)-5-I sobutyl-1,4,7,10-tetraoxacyclododecan-2-one ((S)-5). Two procedures were followed. Method A (improved method): Compound (S)-21 (0.357 g, $1.35 \mathrm{mmol}$ ) was transferred to a small flask together with $\mathrm{CoCl}_{2} \cdot 6 \mathrm{H}_{2} \mathrm{O}(45 \mathrm{mg}, 0.19$ $\mathrm{mmol})$. The blue solution was distilled in a Kugelrohr apparatus $\left(225-240{ }^{\circ} \mathrm{C} ; 2-3 \mathrm{mmHg}\right)$. During $5 \mathrm{~h}, 0.285 \mathrm{~g}$ of a clear oil was collected. TLC analysis showed that the oil consisted mainly of the title product and contained also a small amount of dimer. Alumina column chromatography with hexane/EtOAc (3/1) gave $240 \mathrm{mg}(72 \%)$ of a clear oil $\left(\mathrm{R}_{\mathrm{f}}=0.37\right)$. Method B: Compound (S)-21 (0.346 g, $1.31 \mathrm{mmol})$ and triethylamine $(1.37 \mathrm{~mL}, 9.85 \mathrm{mmol})$ were dissolved in $100 \mathrm{~mL}$ of dry $\mathrm{MeCN}$. This solution was added to a refluxing $\mathrm{MeCN}$ solution (125 mL) containing 2-chloro-6-methylpyridinium iodide $(1.25 \mathrm{~g}, 4.89 \mathrm{mmol})$. The addition was performed with a mechanical syringe over a period of $9 \mathrm{~h}$ at a constant addition rate. During the reaction the color of the solution changed from yellow to brown. After the addition was complete, the solution was heated at reflux for another $0.5 \mathrm{~h}$. Evaporation of the $\mathrm{MeCN}$ and coevaporation with $\mathrm{MeCN}$ to remove triethylamine yielded a brown sticky semisolid to which EtOAc was added. Collection of the liquid and evaporation of the solvent gave $0.75 \mathrm{~g}$ of crude product. Alumina column chromatography with hexane/EtOAc (3/1) yielded $162 \mathrm{mg}$ of 
monomer that was slightly contaminated; further elution with EtOAc gave $24 \mathrm{mg}$ of dimer (7\%). Distillation $\left(100{ }^{\circ} \mathrm{C}, 0.03\right.$ mbar) of the impure monomer in a Kugelrohr apparatus gave a clear yellowish oil. Yield: $110 \mathrm{mg}$ (34\%).

Title Compound: ${ }^{1} \mathrm{H}$ NMR $\left(\mathrm{CDCl}_{3}\right): \delta=4.6\left(1 \mathrm{H}, \mathrm{ddd},{ }^{2} \mathrm{~J}\right.$ $\left.=12.0 \mathrm{~Hz},{ }^{3} \mathrm{~J}=7.0 \mathrm{~Hz},{ }^{3} \mathrm{~J}=2.8 \mathrm{~Hz}\right), 4.35$ and $4.10\left(2 \mathrm{H}, \mathrm{dd},{ }^{2} \mathrm{~J}\right.$ $\left.=16.2 \mathrm{~Hz}, \mathrm{OCH}_{2} \mathrm{COO}\right), 4.1\left(1 \mathrm{H}\right.$, ddd, ${ }^{2} \mathrm{~J}=12.0 \mathrm{~Hz},{ }^{3} \mathrm{~J}=5.9$ $\left.\mathrm{Hz},{ }^{3} \mathrm{~J}=3.0 \mathrm{~Hz}\right), 3.95\left(1 \mathrm{H}, \mathrm{ddd},{ }^{2} \mathrm{~J}=12.0 \mathrm{~Hz},{ }^{3} \mathrm{j}=5.9 \mathrm{~Hz},{ }^{3} \mathrm{~J}\right.$ $=2.6 \mathrm{~Hz}), 3.75\left(1 \mathrm{H}\right.$, ddd, $\left.{ }^{2} \mathrm{~J}=12.0 \mathrm{~Hz},{ }^{3} \mathrm{~J}=3.9 \mathrm{~Hz},{ }^{3} \mathrm{~J}=2.2\right)$, 3.7-3.6 (3H, m), 3.6-3.4 (4H, m), $1.8\left(1 \mathrm{H}, \mathrm{m}, \mathrm{CHCH}_{2} \mathrm{CH}\left(\mathrm{CH}_{3}\right)_{2}\right)$, $1.5\left(1 \mathrm{H}\right.$, ddd, 2J $=14.1 \mathrm{~Hz},{ }^{3} \mathrm{~J}=8.8 \mathrm{~Hz}, 3 \mathrm{~J}=5.5 \mathrm{~Hz}$, $\left.\mathrm{CHCH}^{\prime} \mathrm{H}^{\prime \prime} \mathrm{CH}\left(\mathrm{CH}_{3}\right)_{2}\right), 1.15\left(1 \mathrm{H}\right.$, ddd, $2 \mathrm{j}=13.7 \mathrm{~Hz},{ }^{3} \mathrm{j}=8.8$ $\left.\mathrm{Hz},{ }^{3} \mathrm{~J}=4.5 \mathrm{~Hz}, \mathrm{CHCH}^{\prime} \mathrm{H}^{\prime \prime} \mathrm{CH}\left(\mathrm{CH}_{3}\right)_{2}\right), 0.9(6 \mathrm{H}$, dd, $3 \mathrm{~J}=7.0$ and $\left.6.6 \mathrm{~Hz}, \mathrm{CH}_{2} \mathrm{CH}\left(\mathrm{CH}_{3}\right)_{2}\right)$. ${ }^{13} \mathrm{C} \mathrm{NMR}\left(\mathrm{CDCl}_{3}\right): \delta=170.9(\mathrm{CO})$, 40.3, 24.1, 22.9, and 21.7 (isobutyl carbons), 79.6, 75.7, 71.1, $69.7,69.3,68.7$, and 62.8 (carbons of the ring). FTIR $\left(\mathrm{cm}^{-1}\right)$ : $v=2950,1760,1465,1355,1290,1190,1140,1050,915,870$, 825. TLC: $R_{f}$ (hexane/EtOAc (3/1), alumina) $=0.37, R_{f}$ $(E t O A c$, alumina $)=0.80, R_{f}(E t O A c$, silica $)=0.45, R_{f}$ (hexane $\operatorname{EtOAc}(3 / 1)$, silica $)=0.12$. $[\alpha]^{28}{ }_{\mathrm{D}}\left(\mathrm{c}=3.7 ; \mathrm{CHCl}_{3}\right)=+7.8^{\circ}$. GC-MS (FW = 246.3): 246.3 and 247.3. HRMS: calcd, 246.1467; found, 246.1436. GC analysis on a permethylated $\beta$-cyclodextrin column showed an ee of $97.6 \%$, a value comparable to the ee of the starting compound (S)-leucine (S-7). CD spectroscopy showed a positive Cotton effect at $220 \mathrm{~nm}\left(g_{220}\right.$ $\left.=0.005, \mathrm{MeCN}, 20^{\circ} \mathrm{C}\right) \cdot 35$

Dimer: ${ }^{1} \mathrm{H}$ NMR $\left(\mathrm{CDCl}_{3}\right): \delta=4.4\left(4 \mathrm{H}, \mathrm{dd},{ }^{2} \mathrm{~J}=16.6 \mathrm{~Hz}\right.$, $\left.\mathrm{OCH}_{2} \mathrm{COO}\right), 4.3(4 \mathrm{H}, \mathrm{m}), 3.75-3.45(18 \mathrm{H}, \mathrm{m}), 1.85(2 \mathrm{H}, \mathrm{m}$, $\left.\mathrm{CHCH}_{2} \mathrm{CH}\left(\mathrm{CH}_{3}\right)_{2}\right), 1.5(2 \mathrm{H}$, ddd, 2J $=14.1 \mathrm{~Hz}$, 3j $=8.8 \mathrm{~Hz}$, 3] $\left.=5.5 \mathrm{~Hz}, \mathrm{CH}^{\prime} \mathrm{H}^{\prime \prime} \mathrm{CH}\left(\mathrm{CH}_{3}\right)_{2}\right), 1.15\left(2 \mathrm{H}\right.$, ddd, ${ }^{2} \mathrm{~J}=12.9 \mathrm{~Hz},{ }^{3} \mathrm{~J}=$ $\left.8.5 \mathrm{~Hz}, 3 \mathrm{~J}=4.4 \mathrm{~Hz}, \mathrm{CH}^{\prime} \mathrm{H}^{\prime \prime} \mathrm{CH}\left(\mathrm{CH}_{3}\right)_{2}\right), 0.9(12 \mathrm{H}$, dd, 3j $=6.6$ and $\left.6.6 \mathrm{~Hz}, \mathrm{CH}_{2} \mathrm{CH}\left(\mathrm{CH}_{3}\right)_{2}\right)$. ${ }^{13} \mathrm{C} \mathrm{NMR}\left(\mathrm{CDCl}_{3}\right): \delta=171.1(\mathrm{CO})$, 40.9, 24.4, 23.2, and 22.2 (isobutyl carbons), 77.7, 76.2, 70.6, 70.5, 69.1, 68.1, and 63.7 (carbons of the ring). TLC: $R_{f}$ (hexane/EtOAc (3/1), alumina) $=0.20, R_{f}($ EtOAc, alumina) $=$ $0.80, R_{f}\left(E t O A c\right.$, silica) $=0.45, R_{f}$ (hexane/EtOAc (3/1), silica) $=0.05$. GC-MS ( $F W=492.6) 492.5$ and 493.50 .

(5S)-5-Methyl-1,4,7,10-tetraoxacyclododecan-2-one ((S)6). Compound (S)-22 (0.526 g, $2.37 \mathrm{mmol})$ was transferred to a small flask together with $\mathrm{CoCl}_{2} \cdot 6 \mathrm{H}_{2} \mathrm{O}(51 \mathrm{mg}, 0.21 \mathrm{mmol})$. The blue solution was distilled $\left(225-250^{\circ} \mathrm{C}, 8 \mathrm{mmHg}\right)$ in a Kugelrohr apparatus. During $5 \mathrm{~h} 0.40 \mathrm{~g}$ of a clear oil that mainly consisted of the title product was collected. Alumina column chromatography with hexane/EtOAc (3/1) was performed, giving $270 \mathrm{mg}(56 \%)$ of a pure clear oil $\left(R_{f}=0.30\right)$. ${ }^{1} \mathrm{H}$ NMR $\left(\mathrm{CDCl}_{3}\right): \delta=4.45(1 \mathrm{H}$, ddd, 2 $\mathrm{j}=11.8 \mathrm{~Hz}$, 3ै $=7.0 \mathrm{~Hz}$, $3 \mathrm{~J}=2.6 \mathrm{~Hz}), 4.25$ and $4.05\left(2 \mathrm{H}, \mathrm{dd},{ }^{2} \mathrm{~J}=16.1 \mathrm{~Hz}, \mathrm{OCH}_{2} \mathrm{COO}\right)$, $4.1\left(1 \mathrm{H}\right.$, ddd, 2 $\left.\mathrm{J}=12.0 \mathrm{~Hz},{ }^{3} \mathrm{~J}=5.9 \mathrm{~Hz},{ }^{3} \mathrm{~J}=2.9 \mathrm{~Hz}\right), 3.85$ $\left(1 \mathrm{H}\right.$, ddd, 2 $\left.\mathrm{J}=11.8 \mathrm{~Hz}, 3 \mathrm{~J}=5.9 \mathrm{~Hz},{ }^{3} \mathrm{~J}=2.6 \mathrm{~Hz}\right), 3.8-3.3$ $(8 \mathrm{H}, \mathrm{m}), 1.05\left(3 \mathrm{H}, \mathrm{d},{ }^{2} \mathrm{~J}=6.6 \mathrm{~Hz}, \mathrm{OCH}\left(\mathrm{CH}_{3}\right) \mathrm{CH}_{2} \mathrm{O}\right) .{ }^{13} \mathrm{C} \mathrm{NMR}$ $\left(\mathrm{CDCl}_{3}\right): \delta=171.0$ (CO), 16.9 (methyl carbon), 77.0, 76.1, 71.2, 69.8, 68.7 (2), and 63.2 (carbons of the ring). TLC: $R_{f}$ (hexane/ $\operatorname{EtOAc}(3 / 1)$, alumina) $=0.30, \mathrm{R}_{\mathrm{f}}$ (hexane/EtOAc (1/1), alumina) $=0.45 .[\alpha]^{28} \mathrm{D}\left(\mathrm{c}=4.0 ; \mathrm{CHCl}_{3}\right)=+36.9^{\circ}$. FTIR data $\left(\mathrm{cm}^{-1}\right)$ : $v=2950,1760,1465,1355,1290,1190,1140,1050,915,870$, 825. GC-MS ( $F W=204.2)$ : 204.25. HRMS: calcd, 204.0998; found, 204.0959. GC analysis on a permethylated $\beta$-cyclodextrin column showed an ee of $99.4 \%$, a value comparable to the ee of the starting compound ethyl (S)-lactate (S-10). CD spectroscopy showed a positive Cotton effect at $220 \mathrm{~nm}$ (MeCN, $\left.20{ }^{\circ} \mathrm{C}\right)$.

(2S)-1-[2-(2-(Benzyloxy)ethoxy)ethoxy]-4-methylpentan2-ol ((S)-15). Compound (S)-13 (5.04 g, $25.0 \mathrm{mmol})$ and tosylate $37(11.1 \mathrm{~g}, 31.7 \mathrm{mmol})$ were dissolved in $100 \mathrm{~mL}$ of dry THF. Finely ground $\mathrm{KOH}(85 \%, 6.1 \mathrm{~g}, 92.6 \mathrm{mmol})$ was added, and the mixture was heated at reflux for 2 days. A white precipitate (TsOK) was formed. TLC analysis showed the formation of product $\left(R_{f}(E t O A c\right.$, silica $\left.)=0.63\right)$. After evaporation of the solvent, the remaining mixture was suspended in $\mathrm{H}_{2} \mathrm{O}$. Extraction with $\mathrm{CH}_{2} \mathrm{Cl}_{2}$, drying of the collected organic layers with $\mathrm{MgSO}_{4}$, and evaporation of the solvent in vacuo yielded $15.2 \mathrm{~g}$ of a yellow oil. The oil was dissolved in $75 \mathrm{~mL}$ of $\mathrm{MeOH}$, and after the methanolic solution was cooled in an ice bath for $15 \mathrm{~min}, \mathrm{TsOH} \cdot \mathrm{H}_{2} \mathrm{O}(0.15 \mathrm{~g}, 0.9 \mathrm{mmol})$ was added. TLC analysis (silica) showed that removal of the THP group was complete after $90 \mathrm{~min}$ of stirring at room temper- ature (title product, $\mathrm{R}_{\mathrm{f}}\left(\mathrm{EtOAc}\right.$, silica) $=0.50 ; \mathrm{DHP}, \mathrm{R}_{\mathrm{f}}=0.60$ ). $\mathrm{NaHCO}_{3}$ was added to quench the reaction. $\mathrm{MeOH}$ was evaporated, and coevaporation with $\mathrm{MeOH}$ was performed to remove all DHP. $\mathrm{Et}_{2} \mathrm{O} / \mathrm{H}_{2} \mathrm{O}$ extraction, drying of the collected $\mathrm{Et}_{2} \mathrm{O}$ layers with $\mathrm{MgSO}_{4}$, and evaporation of the solvent yielded $8.4 \mathrm{~g}$ of crude oily product. TLC analysis (silica) with EtOAc showed that the oil contained besides the title compound al so (2S)-4-methyl-1,2-pentanediol $\left(R_{f}=0.22\right)$, tosylate $37\left(R_{f}=0.65\right)$, monobenzyl-diethylene glycol $\left(R_{f}=0.30\right)$, and dibenzylated tetraethylene glycol $\left(R_{f}=0.50\right)$. The last contamination could be discriminated from the title compound by TLC analysis (silica) using $\mathrm{CH}_{2} \mathrm{Cl}_{2}$ as an eluent $\left(\mathrm{R}_{\mathrm{f}}\right.$ values of $0.05-0.10$ and 0 for contamination and product, respectively). Distillation in a Kugelrohr apparatus gave three fractions: I $\left(20-165^{\circ} \mathrm{C}, 0.07 \mathrm{mmHg}\right.$ ), low-boiling side products containing monobenzylated diethylene glycol; II $\left(200-210^{\circ} \mathrm{C}, 0.05 \mathrm{mmHg}\right)$, title product plus some contamination; III, residue, mainly dibenzylated tetraethylene glycol. Fraction II (5.7 g) was purified by silica column chromatography. Sequential el ution with hexane/EtOAc (1/1)-to remove contaminants-and hexane/E tOAc (1/2) - to collect the product-gave $5.0 \mathrm{~g}(68 \%)$ of a clear oil. ${ }^{1} \mathrm{H} N M R\left(\mathrm{CDCl}_{3}\right): \delta=7.4-7.2(5 \mathrm{H}, \mathrm{m}, \mathrm{Ph}), 4.55$ $\left(2 \mathrm{H}, \mathrm{s}, \mathrm{OCH}_{2} \mathrm{Ph}\right), 3.85\left(1 \mathrm{H}, \mathrm{m}, \mathrm{HOCHRCH}{ }_{2} \mathrm{O}\right), 3.7-3.55(8 \mathrm{H}$, m), $3.45\left(1 \mathrm{H}, \mathrm{dd},{ }^{2} \mathrm{~J}=9.9 \mathrm{~Hz},{ }^{3} \mathrm{~J}=2.9 \mathrm{~Hz}, \mathrm{HOCHRCH} \mathrm{H}^{\prime \prime} \mathrm{O}\right)$, $3.25\left(1 \mathrm{H}, \mathrm{dd},{ }^{2} \mathrm{~J}=9.9 \mathrm{~Hz},{ }^{3} \mathrm{~J}=8.0 \mathrm{~Hz}, \mathrm{HOCHRCH} \mathrm{H}^{\prime \prime O}\right), 2.75$ $(1 \mathrm{H}, \mathrm{bs}, \mathrm{OH}), 1.8\left(1 \mathrm{H}, \mathrm{m}, \mathrm{CHCH}_{2} \mathrm{CH}\left(\mathrm{CH}_{3}\right)_{2}\right), 1.4\left(1 \mathrm{H}\right.$, ddd, ${ }^{2} \mathrm{~J}$ $\left.=14.0 \mathrm{~Hz}, 3 \mathrm{~J}=9.0 \mathrm{~Hz},{ }^{3} \mathrm{~J}=5.5 \mathrm{~Hz}, \mathrm{CH}^{\prime} \mathrm{H}^{\prime \prime} \mathrm{CH}\left(\mathrm{CH}_{3}\right)_{2}\right), 1.1$ $\left(1 \mathrm{H}\right.$, ddd, 2 $\mathrm{j}=14.0 \mathrm{~Hz}, 3 \mathrm{~J}=8.8 \mathrm{~Hz}, 3 \mathrm{~J}=4.4 \mathrm{~Hz}, \mathrm{CH}^{\prime} \mathrm{H}^{\prime \prime} \mathrm{CH}-$ $\left.\left(\mathrm{CH}_{3}\right)_{2}\right), 0.95\left(6 \mathrm{H}, \mathrm{dd},{ }^{3} \mathrm{~J}=6.6 \mathrm{~Hz},{ }^{3} \mathrm{~J}=7.0 \mathrm{~Hz}, \mathrm{CH}\left(\mathrm{CH}_{3}\right)_{2}\right) .{ }^{13} \mathrm{C}$ NMR $\left(\mathrm{CDCl}_{3}\right): \delta=138.1,128.2,127.6$, and $127.5(\mathrm{Ph}), 41.8$, 24.3, 23.3, and 22.0 (isobutyl carbons), $73.1\left(\mathrm{OCH}_{2} \mathrm{Ph}\right), 76.2$, $70.5(3 \times), 69.3,68.2$. FTIR $\left(\mathrm{cm}^{-1}\right): v=3464(\mathrm{br}), 2953,2867$, 1455, 1352, 1105, 739, 698. TLC: $R_{f}$ (hexane/EtOAc (1/1), silica $)=0.27 .[\alpha]^{26}\left(\mathrm{c}=6.08 ; \mathrm{CHCl}_{3}\right)=+1.6^{\circ} ;[\alpha]^{27} \mathrm{D}(\mathrm{c}=$ $\left.0.98 ; \mathrm{CHCl}_{3}\right)=+2.4^{\circ} ;[\alpha]^{20}{ }_{\mathrm{D}}(\rho=1 \mathrm{~g} / \mathrm{mL}$; neat $)=-4.3^{\circ}$. Elemental analysis for $\mathrm{C}_{17} \mathrm{H}_{28} \mathrm{O}_{4}(\mathrm{FW}=296)$. Calcd: $\mathrm{C}, 68.92$; $\mathrm{H}$, 9.46. Found: $\mathrm{C}, 68.56 ; \mathrm{H}, 9.54$.

(2S)-1-[2-(2-(Benzyloxy)ethoxy)ethoxy]propan-2-ol ((S)16). Compound (S)-14 (5.15 g, $32.2 \mathrm{mmol}$ ) and 2-(2-(benzyloxy)ethoxy)ethyl tosylate (37) $(13.4 \mathrm{~g}, 38.3 \mathrm{mmol})$ were dissolved in $120 \mathrm{~mL}$ of dry THF. Finely ground $\mathrm{KOH}(85 \%, 7.2$ $\mathrm{g}, 109.3 \mathrm{mmol}$ ) was added, and the mixture was heated with reflux for 3 days. A white suspension was formed. Silica TLC analysis showed that product was present $\left(R_{f}\right.$ (EtOAc, silica) $=0.55$ ). After evaporation of the THF in vacuo, the remaining semisolid was suspended in $\mathrm{H}_{2} \mathrm{O}$. Extraction with $\mathrm{CH}_{2} \mathrm{Cl}_{2}$, drying of the collected organic layers with $\mathrm{MgSO}_{4}$, and evaporation of the solvent yielded $12.9 \mathrm{~g}$ of crude oil. The product was dissolved in $90 \mathrm{~mL}$ of $\mathrm{MeOH}$, and after cooling of the solution in ice for $15 \mathrm{~min}, \mathrm{TsOH} \cdot \mathrm{H}_{2} \mathrm{O}(0.15 \mathrm{~g}, 0.9 \mathrm{mmol})$ was added. Stirring for $4 \mathrm{~h}$ at room temperature gave complete removal of the THP group (the title product had an $R_{f}$ value of 0.30 , while DHP gave an $R_{f}$ value of 0.60 (EtOAc, silica)). $\mathrm{NaHCO}_{3}$ was added to quench the reaction. $\mathrm{MeOH}$ was evaporated, and coevaporation with $\mathrm{MeOH}$ was performed to make sure that all dihydropyran (DHP) was also removed. $\mathrm{H}_{2} \mathrm{O} / \mathrm{Et}_{2} \mathrm{O}$ extraction, drying of the collected $\mathrm{Et}_{2} \mathrm{O}$ layers with $\mathrm{MgSO}_{4}$, and evaporation of the solvent yielded $9.3 \mathrm{~g}$ of crude product. The oil contained besides the title compound also (2S)-1,2-propanediol $\left(R_{f}(E\right.$ tOAc, silica $\left.)=0.08\right)$, tosylate $37\left(R_{f}\right.$ $($ EtOAc, silica $)=0.65)$, monobenzylated diethylene glycol $\left(R_{f}\right.$ $($ EtOAc, silica $)=0.30$ and $R_{f}(\mathrm{MeCN}$, silica $\left.)=0.64\right)$, and dibenzylated tetraethylene glycol $\left(R_{f}(E t O A c\right.$, silica $\left.)=0.50\right)$. Monobenzylated diethylene glycol could be discriminated from the title compound using silica TLC analysis with MeCN as an eluent (title compound $R_{f}=0.67$ ). Distillation in a Kugelrohr apparatus gave three fractions I-III: I (20-150 ${ }^{\circ} \mathrm{C}, 0.05 \mathrm{mmHg}$ ), low-boiling side products, containing monobenzylated diethylene glycol; II $\left(150-170{ }^{\circ} \mathrm{C}, 0.05 \mathrm{mmHg}\right)$, title product plus some contamination; III, residue, mainly dibenzylated tetraethylene glycol. Fraction II (6.5 g) was purified by silica column chromatography. Sequential elution with hexane/EtOAc (1/2)-to remove contaminants $\left(R_{f}\right.$ values of 0.33 and 0.60 )-and with hexane/EtOAc (1/3) - to collect the product-afforded the pure title compound as a clear oil. The absence of monobenzylated diethylene glycol was confirmed 
by TLC analysis (MeCN, silica). Yield: $6.0 \mathrm{~g}(73 \%)$. ${ }^{1} \mathrm{H}$ NMR $\left(\mathrm{CDCl}_{3}\right): \delta=7.4-7.2(5 \mathrm{H}, \mathrm{m}, \mathrm{Ph}), 4.55\left(2 \mathrm{H}, \mathrm{s}, \mathrm{OCH}_{2} \mathrm{Ph}\right), 3.95$ $\left(1 \mathrm{H}, \mathrm{m}, \mathrm{HOCH}\left(\mathrm{CH}_{3}\right) \mathrm{CH}_{2} \mathrm{O}\right), 3.7-3.55(8 \mathrm{H}, \mathrm{m}), 3.45(1 \mathrm{H}, \mathrm{dd}$, 2j $\left.=10.0 \mathrm{~Hz}, 3 \mathrm{j}=3.0 \mathrm{~Hz}, \mathrm{HOCHRCH} \mathrm{H}^{\prime \prime} \mathrm{O}\right), 3.25\left(1 \mathrm{H}, \mathrm{dd},{ }^{2} \mathrm{~J}\right.$ $\left.=10.0 \mathrm{~Hz}, 3 \mathrm{~J}=8.1 \mathrm{~Hz}, \mathrm{HOCHRCH} \mathrm{H}^{\prime \prime} \mathrm{O}\right), 3.0(1 \mathrm{H}, \mathrm{bs}, \mathrm{OH})$, $1.1\left(3 \mathrm{H}, \mathrm{d},{ }^{3} \mathrm{j}=6.6 \mathrm{~Hz}, \mathrm{HOCH}\left(\mathrm{CH}_{3}\right) \mathrm{CH}_{2}\right)$. ${ }^{13} \mathrm{C} \mathrm{NMR}\left(\mathrm{CDCl}_{3}\right)$ : $\delta=138.0,128.2,127.6$, and 127.5 (Ph), $18.4\left(\mathrm{CH}_{3}\right), 73.1\left(\mathrm{OCH}_{2^{-}}\right.$ $\mathrm{Ph}), 76.9,70.4(3 \times), 69.2,66.1$. TLC: $\mathrm{R}_{\mathrm{f}}(\mathrm{EtOAC}$, silica $)=0.30$, $\mathrm{R}_{\mathrm{f}}$ (hexane/EtOAc (1/2), silica) $=0.20, \mathrm{R}_{\mathrm{f}}(\mathrm{MeCN}$, silica) $=0.67$. $[\alpha]^{26}\left(\mathrm{c}=6.63, \mathrm{CHCl}_{3}\right)=+13.3^{\circ}$. FTIR $\left(\mathrm{cm}^{-1}\right): v=3448(\mathrm{br})$, 2867, 1453, 1352, 1290, 1253, 1102, 740, 699.

tert-Butyl (1S)-\{1-[[2-(2-(Benzyloxy)ethoxy)ethoxy]methyl]-3-methylbutoxy $\}$ acetate ((S)-17). Compound (S)$15(8.5 \mathrm{~g}, 28.7 \mathrm{mmol})$ was flushed with $\mathrm{PhM}$ e and dissolved in $40 \mathrm{~mL}$ of tert-BuOH, after which tert-BuOK $(3.58 \mathrm{~g}, 32.0 \mathrm{mmol})$ was added. Short heating to $40{ }^{\circ} \mathrm{C}$ gave a clear, yellow solution. After stirring for $1 \mathrm{~h}$, tert-butyl bromoacetate (10.7 $\mathrm{g}, 54.9 \mathrm{mmol}$ ) was added dropwise. A precipitate $(\mathrm{KBr})$ immediately formed. The reaction mixture was stirred for another hour before the solvent was evaporated in vacuo. $\mathrm{CH}_{2-}$ $\mathrm{Cl}_{2} / \mathrm{H}_{2} \mathrm{O}$ extraction, drying of the collected organic layers with $\mathrm{K}_{2} \mathrm{CO}_{3}$, and evaporation of the solvent yielded $15.1 \mathrm{~g}$ of crude product. Silica column chromatography with hexane/EtOAc (3/1) afforded a pure clear oil $\left(R_{f}=0.23\right)$ in a yield of $8.5 \mathrm{~g}$ (72\%). ${ }^{1} \mathrm{H} N M R\left(\mathrm{CDCl}_{3}\right): \delta=7.4-7.2(5 \mathrm{H}, \mathrm{m}, \mathrm{Ph}), 4.55(2 \mathrm{H}$, $\left.\mathrm{S}, \mathrm{OCH}_{2} \mathrm{Ph}\right), 4.10\left(2 \mathrm{H}, \mathrm{dd},{ }^{2} \mathrm{~J}=16.2 \mathrm{~Hz}, \mathrm{OCH}^{\prime} \mathrm{H}^{\prime \prime C O O t B u}\right)$, 3.7-3.6 $(9 \mathrm{H}, \mathrm{m}), 3.5(2 \mathrm{H}, \mathrm{m}), 1.8\left(1 \mathrm{H}, \mathrm{m}, \mathrm{CH}_{2} \mathrm{CH}\left(\mathrm{CH}_{3}\right)_{2}\right), 1.4$ $\left(9 \mathrm{H}, \mathrm{s}, \mathrm{C}\left(\mathrm{CH}_{3}\right)_{3}\right), 1.4\left(\mathrm{lH}\right.$, ddd, $\left.\mathrm{CHCH} \mathrm{H}^{\prime \prime} \mathrm{CH}\left(\mathrm{CH}_{3}\right)_{2}\right), 1.25(1 \mathrm{H}$, ddd, 2 $\mathrm{j}=13.6 \mathrm{~Hz}$, 3j $=8.2 \mathrm{~Hz}$, 3 $=5.2 \mathrm{~Hz}, \mathrm{CHCH}^{\prime} \mathrm{H}^{\prime \prime}-\mathrm{CH}-$ $\left.\left(\mathrm{CH}_{3}\right)_{2}\right), 0.95\left(6 \mathrm{H}, \mathrm{dd}, 3 \mathrm{~J}=6.6 \mathrm{~Hz}, 3 \mathrm{~J}=6.6 \mathrm{~Hz}, \mathrm{CHCH}_{2} \mathrm{CH}-\right.$ $\left.\left(\mathrm{CH}_{3}\right)_{2}\right) .{ }^{13} \mathrm{C} \mathrm{NMR}\left(\mathrm{CDCl}_{3}\right): \delta=169.8(\mathrm{CO}), 138.0,128.1,127.5$, $127.3(\mathrm{Ph}), 80.8\left(\mathrm{C}\left(\mathrm{CH}_{3}\right)_{3}\right), 40.8,24.1,23.0$, and 22.2 (isobutyl carbons), $27.9\left(\mathrm{C}\left(\mathrm{CH}_{3}\right)_{3}\right), 73.0\left(\mathrm{OCH}_{2} \mathrm{Ph}\right), 77.6,74.8,70.5,70.4$ $(2 \times), 69.2$, and 68.0. FTIR $\left(\mathrm{cm}^{-1}\right): v=2928,2868,1750,1454$, $1368,1300,1224,1126,737,698 .[\alpha]^{25} \mathrm{D}\left(\mathrm{c}=2.11 ; \mathrm{CHCl}_{3}\right)=$ $-12.7^{\circ}$

tert-Butyl (1S)-2-[2-(2-(Benzyloxy)ethoxy)ethoxy]-1methylethoxyacetate ((S)-18). Compound (S)-16 (5.75 g, $22.6 \mathrm{mmol}$ ) was flushed with PhMeand dissolved in $35 \mathrm{~mL}$ of tert-BuOH. tert-BuOK $(2.78 \mathrm{~g}, 24.8 \mathrm{mmol})$ was added, which resulted in a clear, yellow solution. After the solution was stirred for $1 \mathrm{~h}$, tert-butyl bromoacetate $(8.81 \mathrm{~g}, 45.2 \mathrm{mmol})$ was added dropwise. A suspension immediately formed. The reaction mixture was stirred for another hour before the solvent was evaporated. $\mathrm{Et}_{2} \mathrm{O} / \mathrm{H}_{2} \mathrm{O}$ extraction, drying of the collected organic layers with $\mathrm{K}_{2} \mathrm{CO}_{3}$, and evaporation of the solvent yielded $11.3 \mathrm{~g}$ of crude product. Silica column chromatography with hexane/E tOAc (2/1) afforded the pure product $\left(R_{f}=0.22\right)$ as a clear oil in a yield of $6.5 \mathrm{~g}(78 \%)$. ${ }^{1} \mathrm{H} N \mathrm{NMR}$ $\left(\mathrm{CDCl}_{3}\right): \delta=7.4-7.2(5 \mathrm{H}, \mathrm{m}, \mathrm{Ph}), 4.55\left(2 \mathrm{H}, \mathrm{s}, \mathrm{OCH}_{2} \mathrm{Ph}\right), 4.1$ $\left(2 \mathrm{H}, \mathrm{dd},{ }^{2} \mathrm{~J}=16.6 \mathrm{~Hz}, \mathrm{OCH}^{\prime} \mathrm{H}^{\prime \prime C O O t B u}\right), 3.75-3.6(9 \mathrm{H}, \mathrm{m})$, $3.55\left(1 \mathrm{H}, \mathrm{dd}\right.$, 2 $\left.=10.3 \mathrm{~Hz}, 3 \mathrm{~J}=6.2 \mathrm{~Hz}, \mathrm{CH}\left(\mathrm{CH}_{3}\right) \mathrm{CH}^{\prime} \mathrm{H}^{\prime \prime} \mathrm{O}\right)$, $3.45\left(1 \mathrm{H}, \mathrm{dd}, 2^{2} \mathrm{j}=10.3 \mathrm{~Hz}, 3 \mathrm{j}=4.4 \mathrm{~Hz}, \mathrm{CH}\left(\mathrm{CH}_{3}\right) \mathrm{CH}^{\prime} \mathrm{H}^{\prime \prime} \mathrm{O}\right)$, $1.45\left(9 \mathrm{H}, \mathrm{s}, \mathrm{C}\left(\mathrm{CH}_{3}\right)_{3}\right), 1.1\left(3 \mathrm{H}, \mathrm{d}, 3 \mathrm{~J}=6.2 \mathrm{~Hz}, \mathrm{CH}\left(\mathrm{CH}_{3}\right)\right) .{ }^{13} \mathrm{C}$ NMR $\left(\mathrm{CDCl}_{3}\right): \delta=170.1$ (CO), 138.2, 128.2, 127.6, 127.5 (Ph), $17.1\left(\mathrm{CH}_{3}\right), 81.2\left(\mathrm{C}\left(\mathrm{CH}_{3}\right)_{3}\right), 73.1\left(\mathrm{OCH}_{2} \mathrm{Ph}\right), 28.0\left(\mathrm{C}\left(\mathrm{CH}_{3}\right)_{3}\right), 75.5$, 75.2, 70.7, 70.6, 70.5, 69.3, 67.4. FTIR $\left(\mathrm{cm}^{-1}\right): v=2975,2867$, 1748, 1454, 1368, 1298, 1250, 1226, 1127, 1028, 940, 850, 737, 699. $[\alpha]^{26}\left(\mathrm{c}=1.85 ; \mathrm{CHCl}_{3}\right)=-6.6^{\circ}$.

(1S)-1-[[2-(2-(Benzyloxy)ethoxy)ethoxy]methyl]-3methylbutoxyacetic Acid ((S)-19). Compound (S)-17 (8.5 $\mathrm{g}, 20.7 \mathrm{mmol}$ ) was coevaporated twice with $\mathrm{CHCl}_{3}$ before TFA $(23.6 \mathrm{~g}, 207 \mathrm{mmol})$ was added dropwise. After $5 \mathrm{~h}$ of stirring the reaction was complete and the solvent was evaporated. The product was dissolved in $50 \mathrm{~mL}$ of dry $\mathrm{Et}_{2} \mathrm{O}$. The ethereal solution was added dropwise to $100 \mathrm{~mL}$ of $\mathrm{H}_{2} \mathrm{O}$, keeping the $\mathrm{pH}$ of the aqueous layer at $11-12$ by simultaneously adding a $0.4 \mathrm{M} \mathrm{NaOH}$ solution. Thereafter, extraction of the aqueous layer with $\mathrm{Et}_{2} \mathrm{O}$ was performed to remove possible contamination. Remarkably, the volume ratio of both layers was much bigger than expected. While an aqueous/ethereal layer volume ratio of 3/1 was expected, a ratio of 20/1 was observed. It appeared that the product acted as a surfactant, strongly increasing the solubility of $\mathrm{Et}_{2} \mathrm{O}$ in $\mathrm{H}_{2} \mathrm{O}$. The aqueous layer was adjusted to a $\mathrm{pH}$ of 2 with an aqueous $\mathrm{HCl}$ solution, after which it was extracted with $\mathrm{CH}_{2} \mathrm{Cl}_{2}$. The collected organic layers were dried $\left(\mathrm{MgSO}_{4}\right)$ and concentrated to give a clear oil. Yield: $7.1 \mathrm{~g}(97 \%)$. ${ }^{1} \mathrm{H} \mathrm{NMR}\left(\mathrm{CDCl}_{3}\right): \delta=7.4-7.2(5 \mathrm{H}$, $\mathrm{m}, \mathrm{Ph}), 4.55\left(2 \mathrm{H}, \mathrm{s}, \mathrm{OCH}_{2} \mathrm{Ph}\right), 4.3\left(1 \mathrm{H}, \mathrm{d},{ }^{2} \mathrm{~J}=17.1 \mathrm{~Hz}\right.$, $\left.\mathrm{OCH}^{\prime} \mathrm{H}^{\prime \prime} \mathrm{COOH}\right), 4.05\left(1 \mathrm{H}, \mathrm{d},{ }^{2} \mathrm{~J}=17.1 \mathrm{~Hz}, \mathrm{OCH}^{\prime} \mathrm{H}^{\prime \prime} \mathrm{COOH}\right)$, 3.75-3.45 $(11 \mathrm{H}, \mathrm{m}), 1.8\left(1 \mathrm{H}, \mathrm{m}, \mathrm{CH}_{2} \mathrm{CH}\left(\mathrm{CH}_{3}\right)_{2}\right), 1.4(1 \mathrm{H}$, ddd, 2 $\mathrm{J}=13.9 \mathrm{~Hz}$, 3 $\left.=7.3 \mathrm{~Hz}, 3 \mathrm{~J}=6.2 \mathrm{~Hz}, \mathrm{CHCH}^{\prime} \mathrm{H}^{\prime \prime} \mathrm{CH}\left(\mathrm{CH}_{3}\right)_{2}\right)$, $1.25(1 \mathrm{H}$, ddd, 2J $=13.9 \mathrm{~Hz}$, 3j $=7.7 \mathrm{~Hz}, 3 \mathrm{~J}=5.9 \mathrm{~Hz}$, $\left.\mathrm{CHCH}^{\prime} \mathrm{H}^{\prime \prime} \mathrm{CH}\left(\mathrm{CH}_{3}\right)_{2}\right), 0.95(6 \mathrm{H}$, dd, 35 $=6.7 \mathrm{~Hz}, 3 \mathrm{j}=6.7 \mathrm{~Hz}$, $\left.\mathrm{CH}_{2} \mathrm{CH}\left(\mathrm{CH}_{3}\right)_{2}\right)$. ${ }^{13} \mathrm{C} N M R\left(\mathrm{CDCl}_{3}\right): \delta=172.4(\mathrm{CO}), 137.9$, 128.3, 127.7, and 127.6 (Ph), 40.6, 24.3, 23.0, and 22.5 (isobutyl carbons), $73.1\left(\mathrm{OCH}_{2} \mathrm{Ph}\right), 79.8,74.2,70.7,70.5,70.1,69.3$, and 68.4. FTIR $\left(\mathrm{cm}^{-1}\right): v=3100,3063,3030,2950,1763,1453$, 1352, 1247, 1202, 1120, 882, 739, 699. TLC: $R_{\mathrm{f}}$ (EtOAc, silica) $=0-0.10 .[\alpha]^{26}\left(c=2.22 ; \mathrm{CHCl}_{3}\right)=+17.5^{\circ}$. ES-MS: $\mathrm{m} / \mathrm{z}$ $353.1\left[\mathrm{M}-\mathrm{H}^{+}\right]^{-}$

(1S) - $\{$ 2-[2-(2-(B enzy loxy )eth oxy ) ethoxy ]-1methylethoxy acetic Acid, ((S)-20). Compound (S)-18 (6.5 $\mathrm{g}, 17.7 \mathrm{mmol}$ ) was coevaporated twice with $\mathrm{CHCl}_{3}$ before TFA $(20.1 \mathrm{~g}, 176 \mathrm{mmol})$ was added dropwise. After $3 \mathrm{~h}$ of stirring the reaction was complete and the solvent was evaporated. The product was dissolved in $25 \mathrm{~mL}$ of dry $\mathrm{Et}_{2} \mathrm{O}$. The ethereal solution was added dropwise to $100 \mathrm{~mL}$ of $\mathrm{H}_{2} \mathrm{O}$, keeping the $\mathrm{pH}$ of the aqueous layer at 11 by simultaneously adding a 0.4 $\mathrm{M} \mathrm{NaOH}$ solution. Thereafter, extraction of the aqueous layer with $\mathrm{Et}_{2} \mathrm{O}$ was performed to remove possible contamination. The aqueous layer was adjusted to a $\mathrm{pH}$ of 2 with an aqueous $\mathrm{HCl}$ solution, and the aqueous layer was extracted with $\mathrm{CH}_{2-}$ $\mathrm{Cl}_{2}$. The collected organic layers were dried $\left(\mathrm{MgSO}_{4}\right)$ and concentrated to give a clear yellowish oil. Yield: $5.1 \mathrm{~g}(93 \%)$. ${ }^{1} \mathrm{H} \mathrm{NMR}\left(\mathrm{CDCl}_{3}\right): \delta=7.4-7.2(5 \mathrm{H}, \mathrm{m}, \mathrm{Ph}), 4.55\left(2 \mathrm{H}, \mathrm{s}, \mathrm{OCH}_{2-}\right.$ $\mathrm{Ph}), 4.25\left(1 \mathrm{H}, \mathrm{d},{ }^{3} \mathrm{~J}=16.9 \mathrm{~Hz}, \mathrm{CH}^{\prime} \mathrm{H}^{\prime \prime} \mathrm{COOH}\right), 4.05\left(1 \mathrm{H}, \mathrm{d},{ }^{3} \mathrm{~J}\right.$ $\left.=16.9 \mathrm{~Hz}, \mathrm{CH}^{\prime} \mathrm{H}^{\prime \prime} \mathrm{COOH}\right), 3.65(9 \mathrm{H}, \mathrm{m}), 3.5(2 \mathrm{H}, \mathrm{m}), 1.15(3 \mathrm{H}$, $\left.\mathrm{d},{ }^{3} \mathrm{~J}=6.3 \mathrm{~Hz}, \mathrm{CH}\left(\mathrm{CH}_{3}\right)\right)$. ${ }^{13} \mathrm{C} \mathrm{NMR}\left(\mathrm{CDCl}_{3}\right): \delta=172.6(\mathrm{CO})$, $137.9,128.2,127.6$, and $127.4(\mathrm{Ph}), 16.2\left(\mathrm{CH}_{3}\right), 73.0\left(\mathrm{OCH}_{2-}\right.$ $\mathrm{Ph}), 76.8,74.8,70.5,70.4,70.1,69.2,67.1$. FTIR $\left(\mathrm{cm}^{-1}\right): v=$ $3100,3063,3030,2870,1761,1453,1352,1248,1204,1116$, 1028, 915, 883, 823, 742, 699. TLC: $\mathrm{R}_{\mathrm{f}}$ (EtOAC, silica) = $0-0.10 .[\alpha]^{24}\left(\mathrm{C}=2.37 ; \mathrm{CHCl}_{3}\right)=+24.3^{\circ}$. ES-MS: $\mathrm{m} / \mathrm{z} 311.0$ $\left[\mathrm{M}-\mathrm{H}^{+}\right]^{-}$

(1S)-1-[[2-(2-Hydroxyethoxy)ethoxy]methyl]-3-methylbutoxyacetic Acid, ((S)-21). Pd/C (10\%, $0.10 \mathrm{~g})$ was added to a solution of compound (S)-19 $(2.5 \mathrm{~g}, 7.1 \mathrm{mmol})$ in $30 \mathrm{~mL}$ of dioxane and $0.75 \mathrm{~mL}$ of $\mathrm{H}_{2} \mathrm{O}$. Hydrogenation under $50 \mathrm{psi} \mathrm{H}_{2}$ overpressure during $3 \mathrm{~h}$ gave a complete debenzylation. The suspension was filtered, and the remaining solution was coevaporated with $\mathrm{MeCN}$ to remove traces of $\mathrm{H}_{2} \mathrm{O}$. A colorless clear oil was collected. Yield: $1.85 \mathrm{~g}$ (100\%). ${ }^{1} \mathrm{H}$ NMR $\left(\mathrm{CDCl}_{3}\right): \delta=7.3-6.8(2 \mathrm{H}, \mathrm{bs}, \mathrm{COOH}$ and $\mathrm{OH}), 4.3\left(1 \mathrm{H}, \mathrm{d},{ }^{2} \mathrm{~J}\right.$ $\left.=16.9 \mathrm{~Hz}, \mathrm{OCH}^{\prime} \mathrm{H}^{\prime \prime} \mathrm{COOH}\right), 4.05\left(1 \mathrm{H}, \mathrm{d},{ }^{2} \mathrm{j}=16.9 \mathrm{~Hz}\right.$, $\left.\mathrm{OCH} \mathrm{H}^{\prime \prime} \mathrm{COOH}\right), 3.75-3.45(11 \mathrm{H}, \mathrm{m}), 1.8\left(1 \mathrm{H}, \mathrm{m}, \mathrm{CH}_{2} \mathrm{CH}\left(\mathrm{CH}_{3}\right)_{2}\right)$, $1.45(1 \mathrm{H}$, ddd, $2 \mathrm{j}=14.0 \mathrm{~Hz}, 3 \mathrm{~J}=6.6 \mathrm{~Hz}, 3 \mathrm{~J}=6.6 \mathrm{~Hz}$, $\left.\mathrm{CHCH}^{\prime} \mathrm{H}^{\prime \prime} \mathrm{CH}\left(\mathrm{CH}_{3}\right)_{2}\right), 1.25\left(1 \mathrm{H}\right.$, ddd, $2 \mathrm{j}=14.0 \mathrm{~Hz},{ }^{3} \mathrm{~J}=7.7$ $\left.\mathrm{Hz}, 3 \mathrm{~J}=5.9 \mathrm{~Hz}, \mathrm{CHCH}^{\prime} \mathrm{H}^{\prime \prime} \mathrm{CH}\left(\mathrm{CH}_{3}\right)_{2}\right), 0.95(6 \mathrm{H}, \mathrm{dd}$, 3j $=6.7$ $\left.\mathrm{Hz}, 3 \mathrm{~J}=6.6 \mathrm{~Hz}, \mathrm{CH}_{2} \mathrm{CH}\left(\mathrm{CH}_{3}\right)_{2}\right)$. ${ }^{13} \mathrm{C} \mathrm{NMR}\left(\mathrm{CDCl}_{3}\right): \delta=172.2$ (CO), 40.5, 24.4, 22.9, and 22.5 (isobutyl carbons), 79.5, 74.0, $72.4,70.6,69.8,68.2,61.5$. FTIR $\left(\mathrm{cm}^{-1}\right): v=3350(\mathrm{br}), 2953$, $1744,1462,1359,1217,1123,888,756,670 .[\alpha]^{23} \mathrm{D}(\mathrm{c}=2.32$; $\mathrm{MeCN})=+9.1^{\circ}$

(1S)-2-[2-(2-Hydroxyethoxy)ethoxy]-1-methylethoxyacetic Acid ((S)-22). Compound (S)-20 (2.5 g, $8.0 \mathrm{mmol})$ was dissolved in $30 \mathrm{~mL}$ of dioxane and $0.75 \mathrm{~mL}$ of $\mathrm{H}_{2} \mathrm{O}$. $\mathrm{Pd} / \mathrm{C}(10 \%$, $0.10 \mathrm{~g}$ ) was added. Hydrogenation under $50 \mathrm{psi} \mathrm{H}_{2}$ overpressure during $3 \mathrm{~h}$ gave a complete debenzylation. The suspension was filtered and the remaining solution was coevaporated with $\mathrm{MeCN}$ to remove traces of $\mathrm{H}_{2} \mathrm{O}$. A clear oil was collected. Yield: $1.75 \mathrm{~g}(100 \%)$. ${ }^{1} \mathrm{H}$ NMR $\left(\mathrm{CDCl}_{3}\right): \delta=7.3-6.8(2 \mathrm{H}, \mathrm{bs}$, $\mathrm{COOH}$ and $\mathrm{OH}), 4.3\left(1 \mathrm{H}, \mathrm{d},{ }^{2} \mathrm{~J}=17.1 \mathrm{~Hz}, \mathrm{OCH}^{\prime} \mathrm{H}^{\prime \prime} \mathrm{COOH}\right)$, $4.05\left(1 \mathrm{H}, \mathrm{d},{ }^{2} \mathrm{~J}=17.1 \mathrm{~Hz}, \mathrm{OCH}^{\prime} \mathrm{H}^{\prime \prime} \mathrm{COOH}\right), 3.8-3.5(11 \mathrm{H}, \mathrm{m})$, $1.2\left(3 \mathrm{H}, \mathrm{d}, 3 \mathrm{j}=6.3 \mathrm{~Hz}, \mathrm{CH}\left(\mathrm{CH}_{3}\right) \mathrm{CH}_{2}\right) .{ }^{13} \mathrm{C} \mathrm{NMR}\left(\mathrm{CDCl}_{3}\right): \delta$ $=172.3$ (CO), $16.1\left(\mathrm{CH}_{3}\right), 76.3,74.8,72.2,70.4,69.8,67.0$, and 61.3. FTIR $\left(\mathrm{cm}^{-1}\right): v=3340(\mathrm{br}), 2910,1743,1454,1354$, $1221,1121,920,890 .[\alpha]^{23} \mathrm{D}(\mathrm{c}=2.64 ; \mathrm{MeCN})=+22.4^{\circ}$.

(2S)-1-(2-(Benzyloxy)ethoxy)-4-methylpentan-2-ol ((S)23). Alcohol (S)-13 (16.0 g, $79.2 \mathrm{mmol})$, tosylate $34(29.0 \mathrm{~g}$, $94.8 \mathrm{mmol})$, and $\mathrm{KOH}(85 \%, 17.7 \mathrm{~g}, 269 \mathrm{mmol}$ ) were heated at reflux in $300 \mathrm{~mL}$ of dry THF. After $72 \mathrm{~h}$ the reaction was 
stopped. THF was evaporated in vacuo, the remaining product was suspended in $\mathrm{H}_{2} \mathrm{O}$, and extraction with $\mathrm{Et}_{2} \mathrm{O}$ was carried out. The collected organic layers were dried and concentrated to give $29.5 \mathrm{~g}$ of crude product, which was dissolved in 200 $\mathrm{mL}$ of $\mathrm{MeOH}$. After the solution had been allowed to cool down in an ice bath, $\mathrm{TsOH} \cdot \mathrm{H}_{2} \mathrm{O}(0.3 \mathrm{~g}, 1.7 \mathrm{mmol})$ was added. The mixture was stirred at room temperature for $2 \mathrm{~h}$ (TLC-analysis showed that the THP group had been removed). The reaction was quenched by the addition of $\mathrm{NaHCO}_{3}$. After removal of $\mathrm{MeOH}$ and DHP (by coevaporation with $\mathrm{MeOH}$ ), $\mathrm{H}_{2} \mathrm{O} / \mathrm{CH}_{2} \mathrm{Cl}_{2}$ extraction was carried out to yield $25 \mathrm{~g}$ of crude product. TLC analysis showed that, besides the title product, also compound 34 and (2S)-4-methyl-1,2-pentanediol were present. Silica column chromatography was carried out (petroleum ether (40$\left.60{ }^{\circ} \mathrm{C}\right) /$ EtOAc $\left.(2 / 1)\right)$ to remove the diol $\left(R_{f}=0.1\right)$ and most of the tosylate, after which distillation $\left(125^{\circ} \mathrm{C}, 0.01 \mathrm{mmHg}\right)$ in a Kugelrohr apparatus gave the pure oily title compound. Yield: $15.4 \mathrm{~g}(77 \%)$. ${ }^{1} \mathrm{H}$ NMR $\left(\mathrm{CDCl}_{3}\right): \delta=7.3-7.1(5 \mathrm{H}, \mathrm{m}$, $\mathrm{Ph}), 4.5\left(2 \mathrm{H}, \mathrm{OCH}_{2} \mathrm{Ph}\right), 3.8(1 \mathrm{H}, \mathrm{m}), 3.6(4 \mathrm{H}, \mathrm{m}), 3.45(1 \mathrm{H}, \mathrm{dd}$, $\left.{ }^{2} \mathrm{~J}=9.9 \mathrm{~Hz}, 3 \mathrm{~J}=3.0 \mathrm{~Hz}\right), 3.2(1 \mathrm{H}, \mathrm{dd}, 2 \mathrm{~J}=9.9 \mathrm{~Hz}, 3 \mathrm{~J}=8.3$ $\mathrm{Hz}), 2.7(1 \mathrm{H}, \mathrm{bs}), 1.75(1 \mathrm{H}, \mathrm{m}), 1.35\left(1 \mathrm{H}, \mathrm{ddd},{ }^{2} \mathrm{~J}=13.8 \mathrm{~Hz},{ }^{3} \mathrm{~J}\right.$ $\left.=8.8 \mathrm{~Hz},{ }^{3} \mathrm{~J}=5.5, \mathrm{CH}^{\prime} \mathrm{H}^{\prime \prime} \mathrm{CH}\left(\mathrm{CH}_{3}\right)_{2}\right), 1.1\left(1 \mathrm{H}\right.$, ddd, ${ }^{2} \mathrm{~J}=13.8$ $\left.\mathrm{Hz},{ }^{3} \mathrm{j}=8.6 \mathrm{~Hz},{ }^{3} \mathrm{j}=4.2 \mathrm{~Hz}, \mathrm{CH}^{\prime} \mathrm{H}^{\prime \prime} \mathrm{CH}\left(\mathrm{CH}_{3}\right)_{2}\right), 0.9(6 \mathrm{H}$, dd, 3J $\left.=7.0 \mathrm{~Hz}(2 \times), \mathrm{CH}_{2} \mathrm{CH}\left(\mathrm{CH}_{3}\right)_{2}\right) .{ }^{13} \mathrm{C} \mathrm{NMR}\left(\mathrm{CDCl}_{3}\right): \delta=138.0$, 128.4, 127.8, 127.7 (Ph), 41.8, 24.4, 23.5, 22.1 (isobutyl carbons), $73.2\left(\mathrm{CH}_{2} \mathrm{Ph}\right), 76.2,70.6,69.3,68.4$. FTIR $\left(\mathrm{cm}^{-1}\right): v$ $=3448$ (br), 3025, 2943, 2861, 1496, 1449, 1355, 1102, 908,

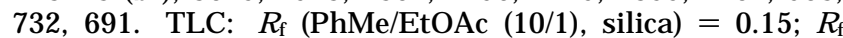
$\left(\mathrm{PhMe} /\right.$ EtOAc $(30 / 1)$, silica) $=0.05 ; \mathrm{R}_{\mathrm{f}}$ (petroleum ether $(40-$ $\left.60{ }^{\circ} \mathrm{C}\right) /$ EtOAC $(2 / 1)$, silica $)=0.35 .[\alpha]^{20} \mathrm{D}(\rho=1 \mathrm{~g} / \mathrm{mL}$; neat $)=$ $-5.7^{\circ} ;[\alpha]^{20} \mathrm{D}\left(\mathrm{c}=2.02 ; \mathrm{CHCl}_{3}\right)=+1.8^{\circ}$.

(1S) -2- $\{$ 1-[[2-(B enzyl oxy)eth oxy ]methyl ]-3methylbutoxy $\}$ ethanol ((S)-24). sec-Alcohol (S)-23 $(2.0 \mathrm{~g}$, $7.9 \mathrm{mmol}$ ), tosylate $35(5.0 \mathrm{~g}, 16.7 \mathrm{mmol})$, and $\mathrm{KOH}(85 \%, 1.85$ $\mathrm{g}, 28.0 \mathrm{mmol}$ ) were heated at reflux for $48 \mathrm{~h}$ in $20 \mathrm{~mL}$ of dry THF. $\mathrm{H}_{2} \mathrm{O} / \mathrm{Et}_{2} \mathrm{O}$ extraction was carried out after the THF had been evaporated. Drying of the collected organic layers and evaporation of the $\mathrm{Et}_{2} \mathrm{O}$ in vacuo yielded $4.2 \mathrm{~g}$ of crude product, which was dissolved in $40 \mathrm{~mL}$ of $\mathrm{MeOH}$. TsOH $\cdot \mathrm{H}_{2} \mathrm{O}(0.10 \mathrm{~g}$, $0.6 \mathrm{mmol}$ ) was added after the methanolic solution was allowed to cool down in an ice bath. The solution was stirred for $1 \mathrm{~h}$ at room temperature, which sufficed to complete the THP removal. $\mathrm{NaHCO}_{3}$ was added to quench the reaction. $\mathrm{MeOH}$ and DHP were removed by evaporation in vacuo, and the resulting semisolid was taken up in $\mathrm{H}_{2} \mathrm{O}$. Extraction with $\mathrm{CH}_{2-}$ $\mathrm{Cl}_{2}$, drying of the organic layers, and removal of the solvent yielded $2.3 \mathrm{~g}$ of crude product. Purification of the title compound was only possible via repeated column chromatography. Starting compound (S)-23 ( $\mathrm{R}_{f}$ (PhMe/EtOAc (3/2), silica) $=0.33 ; \mathrm{R}_{\mathrm{f}}\left(\mathrm{CH}_{2} \mathrm{Cl}_{2} / \mathrm{MeCN}(10 / 1)\right.$, silica $\left.)=0.20\right)$ could be removed by elution with $\mathrm{PhMe} / \mathrm{E}$ tOAc (3/2). Monotosylated ethylene glycol $\left(\mathrm{R}_{\mathrm{f}}(\mathrm{PhMe} / \mathrm{EtOAc}(3 / 2)\right.$, silica $)=0.30 ; \mathrm{R}_{\mathrm{f}}\left(\mathrm{CH}_{2^{-}}\right.$ $\mathrm{Cl}_{2} / \mathrm{MeCN}$, (20/1), silica) $=0.14 ; \mathrm{R}_{\mathrm{f}}\left(\mathrm{CH}_{2} \mathrm{Cl}_{2} / \mathrm{MeCN}\right.$ (10/1), silica) $=0.20-0.40$ ) was difficult to remove. Silica flash column chromatography with $\mathrm{CH}_{2} \mathrm{Cl}_{2} / \mathrm{MeCN}$ (20/1) was the best purification method. Kugel rohr distillation could not be applied in this work-up procedure.Yield: $0.95 \mathrm{~g} \mathrm{(40 \% ).}{ }^{1} \mathrm{H}$ NMR $\left(\mathrm{CDCl}_{3}\right): \delta=7.3-7.1(5 \mathrm{H}, \mathrm{m}, \mathrm{Ph}), 4.6\left(2 \mathrm{H}, \mathrm{OCH}_{2} \mathrm{Ph}\right), 3.75-$ $3.65(9 \mathrm{H}, \mathrm{m}), 3.5-3.4(2 \mathrm{H}, \mathrm{m}), 3.1(1 \mathrm{H}, \mathrm{t}, \mathrm{OH}), 1.75(1 \mathrm{H}, \mathrm{m})$, $1.4\left(1 \mathrm{H}\right.$, ddd, $2 \mathrm{~J}=13.8 \mathrm{~Hz}, 3 \mathrm{~J}=8.4 \mathrm{~Hz}, 3 \mathrm{~J}=5.2 \mathrm{~Hz}, \mathrm{CH}^{\prime} \mathrm{H}^{\prime \prime} \mathrm{CH}-$ $\left.\left(\mathrm{CH}_{3}\right)_{2}\right), 1.2\left(1 \mathrm{H}\right.$, ddd, ${ }^{2} \mathrm{~J}=13.8 \mathrm{~Hz},{ }^{3} \mathrm{~J}=8.5 \mathrm{~Hz},{ }^{3} \mathrm{~J}=4.8 \mathrm{~Hz}$, $\left.\mathrm{CH}^{\prime} \mathrm{H}^{\prime \prime} \mathrm{CH}\left(\mathrm{CH}_{3}\right)_{2}\right), 0.90\left(6 \mathrm{H}, \mathrm{dd},{ }^{3} \mathrm{~J}=7.0 \mathrm{~Hz},{ }^{3} \mathrm{~J}=6.7 \mathrm{~Hz}, \mathrm{CH}-\right.$ $\left.\left(\mathrm{CH}_{3}\right)_{2}\right) .{ }^{13} \mathrm{C} \mathrm{NMR}\left(\mathrm{CDCl}_{3}\right): \delta=138.1,128.3,127.7$, and 127.6 (Ph), $73.2\left(\mathrm{OCH}_{2} \mathrm{Ph}\right), 41.4,24.4,23.3,22.3$ (isobutyl carbons), 77.5, 74.8, 71.9, 70.6, 69.3, 62.3. FTIR $\left(\mathrm{cm}^{-1}\right): v=3448(\mathrm{br})$, 2955, 2861, 1496, 1454, 1355, 1099, 886, 737, 698. TLC: $R_{f}$ (PhMe/EtOAc (3/2), silica) $=0.25 ; \mathrm{R}_{\mathrm{f}}\left(\mathrm{CH}_{2} \mathrm{Cl}_{2} / \mathrm{MeCN}(20 / 1)\right.$, silica $)=0.09 ; \mathrm{R}_{\mathrm{f}}\left(\mathrm{CH}_{2} \mathrm{Cl}_{2} / \mathrm{MeCN}(10 / 1)\right.$, silica $)=0.15 ; \mathrm{R}_{\mathrm{f}}\left(\mathrm{CH}_{2^{-}}\right.$ $\mathrm{Cl}_{2} / \mathrm{MeCN}(5 / 1)$, silica $)=0.20 .[\alpha]^{26}{ }_{\mathrm{D}}\left(\mathrm{c}=0.97 ; \mathrm{CHCl}_{3}\right)=+1.6^{\circ}$.

((2-\{[2(S)-[2-((2-Methoxyethoxy)methoxy)ethoxy]-4methylpentyl]oxy ethoxy)methyl)benzene ((S)-25). Tosylate $36(6.5 \mathrm{~g}, 21.4 \mathrm{mmol})$, compound (S)-23 (4.5 g, 17.9 $\mathrm{mmol})$, and $\mathrm{KOH}(85 \%, 4.0 \mathrm{~g}, 60.7 \mathrm{mmol})$ were heated at reflux for 5 days in $70 \mathrm{~mL}$ of dry THF. After $24 \mathrm{~h}$, portions of compound $36(2.7 \mathrm{~g}, 8.9 \mathrm{mmol})$ and $\mathrm{KOH}(85 \%, 2.0 \mathrm{~g}, 30.3$ $\mathrm{mmol}$ ) were added, because the alcohol (S)-23 was still present in the reaction mixture, while most of the tosylate $\mathbf{3 6}$ had already reacted. After $72 \mathrm{~h}$ and after 4 days, additional portions of tosylate 36 were added $(2.7 \mathrm{~g}$ and $0.8 \mathrm{~g}$, respectively). Finally, the mixture was worked up by subsequent evaporation of the THF, $\mathrm{H}_{2} \mathrm{O} / \mathrm{Et}_{2} \mathrm{O}$ extraction of the remaining semisolid, drying of the collected organic layers $\left(\mathrm{MgSO}_{4}\right)$, and evaporation of the solvent. This yielded $8.7 \mathrm{~g}$ of crude product, which could be purified by repeated silica col umn chromatography using PhMe/EtOAc (5/1) as eluent (tosylate $36\left(\mathrm{R}_{\mathrm{f}}=\right.$ 0.15 ) was hardly present in the crude product; other impurities were detected at $R_{f}$ values $\left.>0.25\right)$. Clear oil. Yield: $4.6 \mathrm{~g}$ (67\%). ${ }^{1} \mathrm{H}$ NMR $\left(\mathrm{CDCl}_{3}\right): \delta=7.4-7.2(5 \mathrm{H}, \mathrm{m}, \mathrm{Ph}), 4.75$ $\left(\mathrm{OCH}_{2} \mathrm{O}\right), 4.55\left(2 \mathrm{H}, \mathrm{OCH}_{2} \mathrm{Ph}\right), 3.85(1 \mathrm{H}, \mathrm{m}), 3.75-3.5(14 \mathrm{H}$, m), $3.4\left(3 \mathrm{H}, \mathrm{s}, \mathrm{OCH}_{3}\right), 1.8(1 \mathrm{H}, \mathrm{m}), 1.5\left(1 \mathrm{H}\right.$, ddd, ${ }^{2} \mathrm{~J}=14.0 \mathrm{~Hz}$, 3) $\left.=8.5 \mathrm{~Hz},{ }^{3} \mathrm{~J}=5.5 \mathrm{~Hz}, \mathrm{CH}^{\prime} \mathrm{H}^{\prime \prime} \mathrm{CH}\left(\mathrm{CH}_{3}\right)_{2}\right), 1.25(1 \mathrm{H}$, ddd, ' $\mathrm{J}$ $\left.=14.0 \mathrm{~Hz}, 3 \mathrm{~J}=8.5 \mathrm{~Hz}, 3 \mathrm{~J}=4.4 \mathrm{~Hz}, \mathrm{CH}^{\prime} \mathrm{H}^{\prime \prime} \mathrm{CH}\left(\mathrm{CH}_{3}\right)_{2}\right), 0.9$ $\left(6 \mathrm{H}, \mathrm{dd}, 3^{3}=6.6 \mathrm{~Hz},{ }_{3} \mathrm{~J}=6.6 \mathrm{~Hz}, \mathrm{CH}\left(\mathrm{CH}_{3}\right)_{2}\right) .{ }^{13} \mathrm{C} \mathrm{NMR}$ $\left(\mathrm{CDCl}_{3}\right): \delta=138.2,128.2,127.6$, and $127.5(\mathrm{Ph}), 95.5\left(\mathrm{OCH}_{2} \mathrm{O}\right)$, $73.1\left(\mathrm{OCH}_{2} \mathrm{Ph}\right), 41.1,24.3,23.3,22.2$ (isobutyl carbons), 58.9 $\left(\mathrm{OCH}_{3}\right), 77.5,74.6,71.7,70.7,69.4,69.3,67.3,66.6$. TLC: $\mathrm{R}_{\mathrm{f}}$ (PhMe/EtOAc (5/1), silica) $=0.11$.

2-\{[2(S)-[2-((2-Methoxyethoxy)methoxy)ethoxy]-4methylpentyl]oxy ethanol ((S)-26). Compound (S)-25 (0.75 g, $1.95 \mathrm{mmol})$ was dissolved in $15 \mathrm{~mL}$ of $\mathrm{MeOH}$. $\mathrm{Pd} / \mathrm{C}(10 \%$, $0.10 \mathrm{~g}$ ) was added after the solution was flushed with nitrogen. The hydrogenation was conducted at $50 \mathrm{psi}_{2}$ overpressure. After $3 \mathrm{~h}$ of stirring, the suspension was subjected to centrifugation. Evaporation of the solvent gave $0.52 \mathrm{~g}(91 \%)$ of clear oily product. ${ }^{1 \mathrm{H}} \mathrm{NMR}\left(\mathrm{CDCl}_{3}\right): \delta=4.75\left(\mathrm{OCH}_{2} \mathrm{O}\right), 3.8(1 \mathrm{H}$ $\mathrm{m}), 3.75-3.5(14 \mathrm{H}, \mathrm{m}), 3.4\left(3 \mathrm{H}, \mathrm{s}, \mathrm{OCH}_{3}\right), 2.9-2.6(1 \mathrm{H}, \mathrm{bs}, \mathrm{OH})$, $1.75(1 \mathrm{H}, \mathrm{m}), 1.5\left(1 \mathrm{H}, \mathrm{ddd},{ }^{2} \mathrm{~J}=13.9 \mathrm{~Hz}, 3 \mathrm{~J}=8.3 \mathrm{~Hz},{ }^{3} \mathrm{~J}=6.2\right.$ $\left.\mathrm{Hz}, \mathrm{CH}^{\prime} \mathrm{H}^{\prime \prime} \mathrm{CH}\left(\mathrm{CH}_{3}\right)_{2}\right), 1.25\left(1 \mathrm{H}, \mathrm{ddd},{ }^{2} \mathrm{j}=13.9 \mathrm{~Hz},{ }^{3} \mathrm{j}=8.1\right.$ $\left.\mathrm{Hz},{ }^{3} \mathrm{~J}=4.8 \mathrm{~Hz}, \mathrm{CH}^{\prime} \mathrm{H}^{\prime \prime} \mathrm{CH}\left(\mathrm{CH}_{3}\right)_{2}\right), 0.9\left(6 \mathrm{H}, \mathrm{dd},{ }^{3} \mathrm{~J}=6.6\right.$ and $\left.6.7 \mathrm{~Hz}, \mathrm{CH}\left(\mathrm{CH}_{3}\right)_{2}\right) .{ }^{13} \mathrm{C} \mathrm{NMR}\left(\mathrm{CDCl}_{3}\right): \delta=95.5\left(\mathrm{OCH}_{2} \mathrm{O}\right), 40.8$, 24.4, 23.2, 22.3 (isobutyl carbons), $61.6\left(\mathrm{CH}_{2} \mathrm{OH}\right), 58.9\left(\mathrm{OCH}_{3}\right)$ 77.4, 74.1, 72.5, 71.7, 69.2, 67.3, 66.7. FTIR $\left(\mathrm{cm}^{-1}\right): v=3460$ (br), 2943, 2872, 1643, 1461, 1361, 1243, 1126, 1049, 850.

2-\{1(S)-[[2-(Benzyloxy)ethoxy]methyl]-3-methylbutoxy\}ethyl Tosylate ((S)-27). Compound (S)-24 (2.7 g, $9.1 \mathrm{mmol})$ in $5 \mathrm{~mL}$ of pyridine was added dropwise to an ice-cooled solution of TsCl $(1.8 \mathrm{~g}, 9.5 \mathrm{mmol})$ in $3 \mathrm{~mL}$ of pyridine. The solution was stirred overnight at $4{ }^{\circ} \mathrm{C}$. The reaction mixture was poured into $10 \mathrm{~mL}$ of ice water, after which $\mathrm{Et}_{2} \mathrm{O}$ and a 1 $\mathrm{M} \mathrm{HCl}$ aqueous solution were added. Extraction with $\mathrm{Et}_{2} \mathrm{O}$ was carried out at a pH value of 1-2. Drying of the collected organic layers and evaporation of the solvent yielded $4.0 \mathrm{~g}$ of product. Sequential elution on a silica column was carried out with $\mathrm{CH}_{2} \mathrm{Cl}_{2} /$ hexane, (3/2)-to remove the excess $\mathrm{TsCl}$-and with $\mathrm{CH}_{2} \mathrm{Cl}_{2} / \mathrm{MeCN}$ (5/1) - to collect the clear oily product. Yield: $3.7 \mathrm{~g}(90 \%)$. ${ }^{1} \mathrm{H} N M R\left(\mathrm{CDCl}_{3}\right): \delta=7.8(2 \mathrm{H}, \mathrm{d}), 7.4-$ $7.2(7 \mathrm{H}, \mathrm{m}, \mathrm{Ph}), 4.55\left(2 \mathrm{H}, \mathrm{OCH}_{2} \mathrm{Ph}\right), 4.1(2 \mathrm{H}, \mathrm{m}), 3.85(1 \mathrm{H}$, ddd, 2 $\left.\mathrm{J}=11.7 \mathrm{~Hz},{ }^{3} \mathrm{~J}=5.1 \mathrm{~Hz},{ }^{3} \mathrm{~J}=4.0 \mathrm{~Hz}\right), 3.7(1 \mathrm{H}$, ddd, 2 $\mathrm{J}$ $\left.=11.7 \mathrm{~Hz},{ }^{3} \mathrm{~J}=5.9 \mathrm{~Hz},{ }^{3} \mathrm{~J}=4.6 \mathrm{~Hz}\right), 3.6-3.4(7 \mathrm{H}, \mathrm{m}), 2.45$ $\left(3 \mathrm{H}, \mathrm{s}, \mathrm{PhCH}_{3}\right), 1.65(1 \mathrm{H}, \mathrm{m}), 1.35\left(1 \mathrm{H}, \mathrm{ddd},{ }^{2} \mathrm{j}=14.0 \mathrm{~Hz}, 3 \mathrm{~J}\right.$ $\left.=8.6 \mathrm{~Hz}, 3 \mathrm{~J}=5.3 \mathrm{~Hz}, \mathrm{CH}^{\prime} \mathrm{H}^{\prime \prime} \mathrm{CH}\left(\mathrm{CH}_{3}\right)_{2}\right), 1.15\left(1 \mathrm{H}, \mathrm{ddd},{ }^{2} \mathrm{~J}=\right.$ $\left.14.0 \mathrm{~Hz}, 3 \mathrm{~J}=8.8 \mathrm{~Hz},{ }^{3} \mathrm{~J}=4.4 \mathrm{~Hz}, \mathrm{CH}^{\prime} \mathrm{H}^{\prime \prime} \mathrm{CH}\left(\mathrm{CH}_{3}\right)_{2}\right), 0.85(6 \mathrm{H}$, dd, 3f $=6.6 \mathrm{~Hz}$, 3J $\left.=7.0 \mathrm{~Hz}, \mathrm{CH}\left(\mathrm{CH}_{3}\right)_{2}\right)$. ${ }^{13} \mathrm{C} \mathrm{NMR}\left(\mathrm{CDCl}_{3}\right)$ : $\delta=138.1,128.2,127.8$, and $127.5(\mathrm{Ph}), 144.5,132.9,129.6$, and 127.4 (Ts), $73.0\left(\mathrm{OCH}_{2} \mathrm{Ph}\right), 40.8,24.1,23.2,22.0$ (isobutyl carbons), $21.5\left(\mathrm{CH}_{3}\right), 77.6,74.7,70.6,69.6,69.3,67.6$. FTIR $\left(\mathrm{cm}^{-1}\right): v=3063,3030,2954,2867,1598,1495,1452,1357$, $1291,1177,1098,1019,921,816,774,738,699,663$. TLC: $\mathrm{R}_{\mathrm{f}}\left(\mathrm{CH}_{2} \mathrm{Cl}_{2} / \mathrm{MeCN}\right.$ (5/1), silica) $=0.90 ; \mathrm{R}_{\mathrm{f}}\left(\mathrm{CH}_{2} \mathrm{Cl}_{2} /\right.$ hexane (3/ $2)$, silica $)=0.10$. $[\alpha]^{22}{ }_{\mathrm{D}}\left(\mathrm{c}=0.99 ; \mathrm{CHCl}_{3}\right)=-9.6^{\circ}$.

(4S,13S)-1-((2-Methoxyethoxy)methoxy)-4,13-diisobutyl-17-(benzyloxy)-3,6,9,12,15- pentaoxaheptadecane (SS)28). Tosylate (S)-27 (2.2 g, $4.89 \mathrm{mmol})$, alcohol (S)-26 (1.1 g, $3.74 \mathrm{mmol})$, and $\mathrm{KOH}(85 \%, 1.0 \mathrm{~g}, 15.2 \mathrm{mmol})$ were heated at reflux in $15 \mathrm{~mL}$ of dry THF. After 3 days the solvent was evaporated in vacuo and the resulting semisolid was suspended in $15 \mathrm{~mL}$ of $\mathrm{H}_{2} \mathrm{O}$. Extraction of the aqueous layer with $\mathrm{Et}_{2} \mathrm{O}$ was followed by drying of the collected organic layers $\left(\mathrm{MgSO}_{4}\right)$. Evaporation of $\mathrm{Et}_{2} \mathrm{O}$ gave $2.6 \mathrm{~g}$ of crude product. Silica column chromatography using PhMe/EtOAc (1/1) afforded an oily, yellowish product $\left(R_{f}=0.18\right)$. Yield: $1.45 \mathrm{~g}$ (68\%). (TLC analysis reveal ed impurities such as the starting 
compounds $(S)-26\left(R_{f}=0.05\right)$ and $(S)-27\left(R_{f}=0.68\right)$, hydrolyzed (S)-27 (=(S)-24; $R_{f}=0.27$ ), and the coupled product of (S)-27 and $(S)-24\left(R_{f}=0.55\right)$; all $R_{f}$-values were measured with PhMe/EtOAc (1/1), silica.) ${ }^{1} \mathrm{H}$ NMR $\left(\mathrm{CDCl}_{3}\right): \delta=7.4-7.2(5 \mathrm{H}$, $\mathrm{m}, \mathrm{Ph}), 4.75\left(2 \mathrm{H}, \mathrm{s}, \mathrm{OCH}_{2} \mathrm{O}\right), 4.55\left(2 \mathrm{H}, \mathrm{OCH}_{2} \mathrm{Ph}\right), 3.85(2 \mathrm{H}$, $\mathrm{m}), 3.7-3.45(24 \mathrm{H}, \mathrm{m}), 3.4\left(3 \mathrm{H}, \mathrm{s}, \mathrm{OCH}_{3}\right), 1.7(2 \mathrm{H}, \mathrm{m}), 1.45$ $(2 \mathrm{H}, \mathrm{m}), 1.25(2 \mathrm{H}, \mathrm{m}), 0.90(12 \mathrm{H}, 4 \times \mathrm{d}, 3 \mathrm{~J}=7.0 \mathrm{~Hz}, 3 \mathrm{~J}=6.6$ $\left.\mathrm{Hz},{ }^{3} \mathrm{~J}=6.6 \mathrm{~Hz},{ }^{3} \mathrm{~J}=6.6 \mathrm{~Hz}\right) .{ }^{13} \mathrm{C} \mathrm{NMR}\left(\mathrm{CDCl}_{3}\right): \delta=138.2$, 128.2, 127.5, and 127.4 (Ph), $73.1\left(\mathrm{OCH}_{2} \mathrm{Ph}\right), 41.1(2 \times), 24.3(2 \times)$, $23.3(2 \times)$, and $22.2(2 \times)$ (isobutyl carbons), $58.7\left(\mathrm{OCH}_{3}\right), 95.4$ $\left(\mathrm{OCH}_{2} \mathrm{O}\right), 77.4(2 \times), 74.5,74.4,71.6,70.8,70.7,70.6,70.4$, $69.3(2 \times), 69.2,67.3,66.5$. FTIR $\left(\mathrm{cm}^{-1}\right): v=2955,2869,1454$, 1366, 1291, 1244, 1201, 1117, 1048, 851, 737, 698. TLC: $\mathrm{R}_{\mathrm{f}}$ (PhMe/EtOAc, (1/1), silica) = 0.18; $\mathrm{R}_{\mathrm{f}}(\mathrm{PhMe/EtOAc}(1 / 2)$, silica) $=0.27 .[\alpha]^{20} \mathrm{D}(\mathrm{c}=3.5 ; \mathrm{MeCN})=-12.0^{\circ}$.

(4S,135)-1-Hydroxy-4,13-diisobutyl-17-(benzyloxy)-3,6,9,12,15-pentaoxaheptadecane ((SS)-29). MEM-ether (SS)$28(2.0 \mathrm{~g}, 3.5 \mathrm{mmol})$ was dissolved in $10 \mathrm{~mL}$ of dry $\mathrm{CH}_{2} \mathrm{Cl}_{2}$, and the resulting solution was added to $\mathrm{ZnBr}_{2}(7.3 \mathrm{~g}, 32.4$ $\mathrm{mmol})$. The resulting suspension was stirred for 3 days. Thereafter, the reaction was quenched with a saturated $\mathrm{NaHCO}_{3}$ solution. Extraction with $\mathrm{CH}_{2} \mathrm{Cl}_{2}$, drying of the collected organic layers, and evaporation of the solvent gave a crude product, which was contaminated with MEM-ether (SS)-28 $\left(\mathrm{R}_{\mathrm{f}}\left(\mathrm{CH}_{2} \mathrm{Cl}_{2} / \mathrm{EtOAC}(1 / 1)\right.\right.$, silica $\left.)=0.25\right)$ and with $\alpha, \omega$ diol (SS)-33 (simultaneous removal of the benzyl group had also occurred). Silica column chromatography was carried out using $\mathrm{CH}_{2} \mathrm{Cl}_{2} / \mathrm{EtOAC}(1 / 1)$ as eluent to yield $0.75 \mathrm{~g} \mathrm{(44 \% )}$ of the oily product $\left(R_{f}=0.25\right)$. $\alpha, \omega$-Diol (SS)-33 was also isolated, using MeCN/MeOH $(20 / 1)$ as an eluent $\left(R_{f}=0.25\right)$. Yield: 0.1 $\mathrm{g}(7 \%)$.

Title Compound. ${ }^{1} \mathrm{H}$ NMR $\left(\mathrm{CDCl}_{3}\right): \delta=7.4-7.2(5 \mathrm{H}, \mathrm{m}$, $\mathrm{Ph}), 4.55\left(2 \mathrm{H}, \mathrm{OCH}_{2} \mathrm{Ph}\right), 3.85(2 \mathrm{H}, \mathrm{m}), 3.7-3.45(2 \mathrm{H}, \mathrm{m}), 3.15$ $(1 \mathrm{H}, \mathrm{t}, \mathrm{OH}), 1.75(2 \mathrm{H}, \mathrm{m}), 1.45(2 \mathrm{H}, \mathrm{m}), 1.2(2 \mathrm{H}, \mathrm{m}), 0.90(12 \mathrm{H}$, $\left.4 \times \mathrm{d},{ }^{3} \mathrm{~J}=7.0 \mathrm{~Hz},{ }^{3} \mathrm{~J}=6.6 \mathrm{~Hz},{ }^{3} \mathrm{~J}=6.6 \mathrm{~Hz},{ }^{3} \mathrm{~J}=6.6 \mathrm{~Hz}\right) .{ }^{13} \mathrm{C}$ NMR $\left(\mathrm{CDCl}_{3}\right): \delta=138.2,128.3,127.6$, and $127.5(\mathrm{Ph}), 73.1$ $\left(\mathrm{OCH}_{2} \mathrm{Ph}\right), 41.3,41.1,24.4(2 \times), 23.3(2 \times)$, and $22.2(2 \times)$, (isobutyl carbons), 77.5, 77.4, 74.8, 74.4, 71.9, 70.8, 70.7, 70.6, 70.3, 69.4, 69.3, 62.2. FTIR $\left(\mathrm{cm}^{-1}\right): v=3470,2953,2868,1586$, 1467, 1367, 1110. TLC: $\mathrm{R}_{\mathrm{f}}\left(\mathrm{CH}_{2} \mathrm{Cl}_{2} / \operatorname{EtOAC}(1 / 1)\right.$, silica) $=0.25$; $\mathrm{R}_{\mathrm{f}}(\mathrm{MeCN} / \mathrm{MeOH}(20 / 1)$, silica $)=0.50$.

$\alpha, \omega$-Diol (SS)-33. ${ }^{1} \mathrm{H} N M R\left(\mathrm{CDCl}_{3}\right): \delta=3.8-3.4(22 \mathrm{H}, \mathrm{m})$, $2.90(2 \mathrm{H}, \mathrm{bs}, \mathrm{OH}), 1.65(2 \mathrm{H}, \mathrm{m}), 1.50(2 \mathrm{H}, \mathrm{m}), 1.2(2 \mathrm{H}, \mathrm{m})$, $0.90\left(12 \mathrm{H}, \mathrm{d},{ }^{2} \mathrm{j}=6.7 \mathrm{~Hz}(4 \times)\right) .{ }^{13} \mathrm{C} \mathrm{NMR}\left(\mathrm{CDCl}_{3}\right): \delta=39.9$, 39.7, 24.5, 24.4, $22.8(2 \times), 22.6,22.5$ (isobutyl carbons), 61.0, $60.6\left(\mathrm{CH}_{2} \mathrm{OH}, 2 \times\right), 76.5,76.4,72.9,72.1,72.0,70.2,69.8,69.4$, 69.2, 67.1. TLC: $\mathrm{R}_{\mathrm{f}}\left(\mathrm{CH}_{2} \mathrm{Cl}_{2} / \mathrm{EtOAC}(1 / 1)\right.$, silica) $=0.05$. FTIR $\left(\mathrm{cm}^{-1}\right): v=3333,2952,2872,1666,1587,1468,1367,1260$, $1108,953,891,801$.

tert-Butyl (7S,16S)-7,16-Diisobutyl-20-(benzyloxy)-3,6,9,12,15,18-hexaoxaeicosanate ((SS)-30). Alcohol (SS)-29 $(0.75 \mathrm{~g}, 1.55 \mathrm{mmol})$ was dissolved in $2.5 \mathrm{~mL}$ of tert-BuOH. tertBuOK $(0.18 \mathrm{~g}, 1.61 \mathrm{mmol})$ was added, and the suspension was stirred for $1 \mathrm{~h}$, resulting in a clear solution. tert-Butyl bromoacetate $(0.57 \mathrm{~g}, 2.92 \mathrm{mmol})$ was added dropwise. A preci pitate immediately formed. The sol vent was evaporated in vacuo after the suspension was stirred for $0.5 \mathrm{~h}$. The remaining semisolid was suspended in an aqueous $\mathrm{NaCl}$ solution, which was extracted with $\mathrm{CH}_{2} \mathrm{Cl}_{2}$. Drying of the collected organic layers and evaporation of the solvent yielded $1.04 \mathrm{~g}$ of crude product, which was slightly contaminated with compound (SS)-29 $\left(\mathrm{R}_{\mathrm{f}}\left(\mathrm{CH}_{2} \mathrm{Cl}_{2} / \mathrm{EtOAC}(3 / 1)\right.\right.$, silica $\left.)=0.05\right)$. Silica column chromatography using $\mathrm{CH}_{2} \mathrm{Cl}_{2} / \mathrm{EtOAC}$ (3/1) gave the pure title compound as a clear oil $\left(R_{f}=0.30\right)$. Yield: 0.82 $\mathrm{g}(85 \%)$. ${ }^{1} \mathrm{H} \mathrm{NMR}\left(\mathrm{CDCl}_{3}\right): \delta=7.4-7.2(5 \mathrm{H}, \mathrm{m}, \mathrm{Ph}), 4.55(2 \mathrm{H}$, $\left.\mathrm{OCH}_{2} \mathrm{Ph}\right), 4.05\left(2 \mathrm{H}, \mathrm{s}, \mathrm{OCH}_{2} \mathrm{COOR}\right), 3.8(2 \mathrm{H}, \mathrm{m}), 3.7-3.4(2 \mathrm{OH}$, $\mathrm{m}), 1.7(2 \mathrm{H}, \mathrm{m}), 1.5\left(9 \mathrm{H}, \mathrm{s}, \mathrm{C}\left(\mathrm{CH}_{3}\right)_{3}\right), 1.45(2 \mathrm{H}, \mathrm{m}), 1.2(2 \mathrm{H}$, m), $0.90\left(12 \mathrm{H}, 4 \times \mathrm{d}, 3 \mathrm{~J}=7.0 \mathrm{~Hz},{ }^{3} \mathrm{~J}=7.0 \mathrm{~Hz},{ }^{3} \mathrm{~J}=7.0 \mathrm{~Hz},{ }^{3} \mathrm{~J}\right.$ $=6.6 \mathrm{~Hz}) \cdot{ }^{13} \mathrm{C} \mathrm{NMR}\left(\mathrm{CDCl}_{3}\right): \delta=138.1,128.1,127.4$, and $127.3(\mathrm{Ph}), 169.5(\mathrm{CO}), 73.0\left(\mathrm{OCH}_{2} \mathrm{Ph}\right), 41.0,40.9,24.2(2 \times)$, 23.2(2x), and $22.1(2 \times)$ (isobutyl carbons), $81.1\left(\mathrm{C}\left(\mathrm{CH}_{3}\right)_{3}\right), 77.3$, 77.2, $74.3(2 \times)$, 70.8, 70.7, 70.6, 70.5, 70.3, $69.2(3 \times)$, 68.8. FTIR $\left(\mathrm{cm}^{-1}\right): v=2954,2868,1749,1454,1368,1298,1225$, $1120,950,844,736,698$. TLC: $R_{f}(\mathrm{MeCN} / \mathrm{MeOH}$ (10/1), silica) $=0.6$. $[\alpha]^{24}\left(\mathrm{C}=2.6 ; \mathrm{CHCl}_{3}\right)=-16.1^{\circ}$.
(7S,16S)-7,16-Diisobutyl-20-(benzyloxy)-3,6,9,12,15,18hexaoxaeicosanoic Acid ((SS)-31). Compound (SS)-30 $(0.82 \mathrm{~g}, 1.37 \mathrm{mmol})$ was dissolved in TFA ( $1.7 \mathrm{~g})$. Stirring for $1 \mathrm{~h}$ resulted in hydrolysis of the tert-butyl ester. The solvent was evaporated, and the resulting oil, which still contained significant amounts of the TFA, was dissolved in $10 \mathrm{~mL}$ of dry $\mathrm{Et}_{2} \mathrm{O}$. This ethereal solution was added dropwise to $\mathrm{H}_{2} \mathrm{O}$, which was kept at a constant $\mathrm{pH}$ of 2 by simultaneous addition of a $0.4 \mathrm{M} \mathrm{NaOH}$ solution. After the addition was completed, the aqueous layer was extracted with $\mathrm{Et}_{2} \mathrm{O}$. Drying of the collected organic layers and evaporation of the solvent gave $0.70 \mathrm{~g}(94 \%)$ of oily product. ${ }^{1} \mathrm{H} \mathrm{NMR}\left(\mathrm{CDCl}_{3}\right): \delta=7.4-7.2$ $(5 \mathrm{H}, \mathrm{m}, \mathrm{Ph}), 4.55\left(2 \mathrm{H}, \mathrm{OCH}_{2} \mathrm{Ph}\right), 4.15\left(2 \mathrm{H}, \mathrm{s}, \mathrm{OCH}_{2} \mathrm{COOH}\right)$, $3.85(2 \mathrm{H}, \mathrm{m}), 3.7-3.4(2 \mathrm{H}, \mathrm{m}), 1.75(2 \mathrm{H}, \mathrm{m}), 1.45(2 \mathrm{H}, \mathrm{m})$, $1.25(2 \mathrm{H}, \mathrm{m}), 0.90\left(12 \mathrm{H}, 4 \times \mathrm{d},{ }^{3} \mathrm{~J}=7.0 \mathrm{~Hz},{ }^{3} \mathrm{~J}=7.0 \mathrm{~Hz},{ }^{3} \mathrm{~J}=\right.$ $6.6 \mathrm{~Hz}, 3 \mathrm{~J}=6.6 \mathrm{~Hz}) .{ }^{13} \mathrm{C} \mathrm{NMR}\left(\mathrm{CDCl}_{3}\right): \delta=138.0,128.1$, 127.5, and $127.4(\mathrm{Ph}), 172.5(\mathrm{CO}), 72.9\left(\mathrm{OCH}_{2} \mathrm{Ph}\right), 40.9,40.5$, 24.3, 24.2, 23.1, 23.0, and 22.1(2x) (isobutyl carbons), 77.6, 77.3, 74.2 (2×), 71.4, 70.6, 70.5, 70.4, 70.3, 69.2, 69.1, 69.0, 68.4. FTIR $\left(\mathrm{cm}^{-1}\right): v=3100,2955,2872,1761,1454,1366$, $1260,1104,876,799,737,698$. TLC: $R_{f}(\mathrm{MeCN} / \mathrm{MeOH}(1 / 1)$, silica $)=0.50 ; \mathrm{R}_{\mathrm{f}}(\mathrm{MeCN} / \mathrm{MeOH}(10 / 1)$, silica $)=0 . \quad[\alpha]^{20}{ }_{\mathrm{D}}(\mathrm{c}=$ 2.0; $\mathrm{MeCN})=-10.3^{\circ}$. ES-MS: $\mathrm{m} / \mathrm{z} 541.4\left[\mathrm{M}-\mathrm{H}^{+}\right]^{-}$

(7S,16S)-7,16-Diisobutyl-20-hydroxy-3,6,9,12,15,18hexaoxaeicosanoic Acid ((SS)-32). The benzyl-protected precursor (SS)-31 (250 mg, $0.46 \mathrm{mmol}$ ) was dissolved in $9 \mathrm{~mL}$ of dioxane and $1 \mathrm{~mL}$ of $\mathrm{H}_{2} \mathrm{O}$. A catalytic amount of $\mathrm{Pd} / \mathrm{C}(10 \%)$ was added to the solution, and hydrogenation at $50 \mathrm{psi} \mathrm{H}_{2}$ overpressure was carried out during $3 \mathrm{~h}$. Filtration and evaporation of the solvents gave the clear, oily title compound in a quantitative yield $(210 \mathrm{mg})$. ${ }^{1} \mathrm{H} \mathrm{NMR}\left(\mathrm{CDCl}_{3}\right): \delta=5.3$ $(2 \mathrm{H}, \mathrm{bs}, \mathrm{OH}$ and $\mathrm{COOH}), 4.1\left(2 \mathrm{H}, \mathrm{s}, \mathrm{CH}_{2} \mathrm{COOH}\right), 3.8-3.4(22 \mathrm{H}$, $\mathrm{m}), 1.7(2 \mathrm{H}, \mathrm{m}), 1.4(2 \mathrm{H}, \mathrm{m}), 1.2(2 \mathrm{H}, \mathrm{m}), 0.90(12 \mathrm{H}, 4 \times \mathrm{d}, 3 \mathrm{~J}$ $\left.=6.6 \mathrm{~Hz},{ }^{3} \mathrm{~J}=6.6 \mathrm{~Hz},{ }^{3} \mathrm{~J}=6.6 \mathrm{~Hz},{ }^{3} \mathrm{~J}=6.6 \mathrm{~Hz}\right) .{ }^{13} \mathrm{C} \mathrm{NMR}$ $\left(\mathrm{CDCl}_{3}\right): \delta=172.3$ (CO), 40.6, 40.5, 24.6, 24.5, 23.2, 23.1, 22.5, and 22.4 (isobutyl carbons), 78.0, 77.5, 74.3, 74.0, 72.5, 71.8, $70.8,70.6,70.5,69.1(2 \times), 69.0,61.6$.

(4S,13S)-4,13-Diisobutyl-17-hydroxy-3,6,9,12,15-pentaoxaheptadecanol ((SS)-33). Details concerning $\alpha, \omega$-diol (SS)-33 can be found in the experimental discussion of compound (SS)-29.

2-(Benzyloxy)ethyl Tosylate (34). ${ }^{14}$ A 2 L flask was charged with $500 \mathrm{~mL}$ of tert-butanol, and tert-BuOK $(56.2 \mathrm{~g}$, $0.50 \mathrm{~mol}$ ) was added in portions. The suspension was stirred and heated to $50{ }^{\circ} \mathrm{C}$ to dissolve all the butoxide. The resulting solution was added dropwise to a stirred solution of ethylene glycol $(62.5 \mathrm{~g}, 1.01 \mathrm{~mol})$. After the addition was complete, the solution was stirred for $1 \mathrm{~h}$. The solvent was evaporated in vacuo to yield a sticky, brown substance to which $200 \mathrm{~mL}$ of dioxane, tetrabutylammonium chloride $(2.8 \mathrm{~g}, 2 \mathrm{~mol} \%)$, and benzyl chloride $(63.3 \mathrm{~g}, 0.50 \mathrm{~mol})$ were added. The suspension was mechanically stirred at $55-65^{\circ} \mathrm{C}$ overnight, after which the dioxane was evaporated. The residue was dissolved in a mixture of $500 \mathrm{~mL}$ of $\mathrm{H}_{2} \mathrm{O}$ and $300 \mathrm{~mL}$ of $\mathrm{Et}_{2} \mathrm{O}$. The $\mathrm{pH}$ of the $\mathrm{H}_{2} \mathrm{O}$ layer was adjusted to 6 by the addition of an aqueous 1 $\mathrm{M} \mathrm{H}_{2} \mathrm{SO}_{4}$ solution. The $\mathrm{Et}_{2} \mathrm{O}$ layer was removed, and two extractions with $300 \mathrm{~mL}$ of $\mathrm{Et}_{2} \mathrm{O}$ were conducted. The collected $\mathrm{Et}_{2} \mathrm{O}$ layers were washed with $100 \mathrm{~mL}$ of $\mathrm{H}_{2} \mathrm{O}$, dried with $\mathrm{MgSO}_{4}$, and concentrated. The brown oily residue was purified by distillation $\left(80{ }^{\circ} \mathrm{C}, 0.1 \mathrm{mmHg}\right.$ ) to give monobenzylated glycol. Yield: $44.7 \mathrm{~g}$ (59\%). The spectroscopic data were in agreement with those found in the literature. ${ }^{36}{ }^{1} \mathrm{H} N M R$ $\left(\mathrm{CDCl}_{3}\right): \delta=7.4-7.3(5 \mathrm{H}, \mathrm{m}, \mathrm{Ph}), 4.55\left(2 \mathrm{H}, \mathrm{s}, \mathrm{OCH}_{2} \mathrm{Ph}\right), 3.7$ $\left(2 \mathrm{H}, \mathrm{t}, \mathrm{CH}_{2} \mathrm{OH}\right), 3.55\left(2 \mathrm{H}, \mathrm{t}, \mathrm{CH}_{2}-\mathrm{CH}_{2} \mathrm{OH}\right), 2.7(1 \mathrm{H}, \mathrm{bs}, \mathrm{OH})$. ${ }^{13} \mathrm{C} \mathrm{NMR}\left(\mathrm{CDCl}_{3}\right): \delta=137.7,128.3,127.7,127.6(\mathrm{Ph}), 73.0$ $\left(\mathrm{OCH}_{2} \mathrm{Ph}\right), 71.3\left(\mathrm{CH}_{2} \mathrm{CH}_{2} \mathrm{OH}\right)$, and $61.6\left(\mathrm{CH}_{2} \mathrm{OH}\right)$. TLC: $\mathrm{R}_{\mathrm{f}}$ (hexane/EtOAc $(1 / 1)$, silica) $=0.30 ; R_{f}$ (hexane/EtOAc (3/1), silica $)=0.13$. Monobenzylated glycol $(125.3 \mathrm{~g}, 0.82 \mathrm{~mol}), \mathrm{TsCl}$ (157.8 g, $0.83 \mathrm{~mol}$ ), and $500 \mathrm{~mL}$ of $\mathrm{CH}_{2} \mathrm{Cl}_{2}$ were mixed in a 2 $\mathrm{L}$ flask. The solution was cooled to $0{ }^{\circ} \mathrm{C}$ in a salt ice bath. F reshly powdered $\mathrm{KOH}(85 \%, 185.9 \mathrm{~g}, 2.82 \mathrm{~mol}$ ) was added in small portions, while keeping the temperature of the suspension below $5^{\circ} \mathrm{C}$. The mixture was stirred overnight at $4{ }^{\circ} \mathrm{C}$, after which it was poured into $300 \mathrm{~mL}$ of $\mathrm{CH}_{2} \mathrm{Cl}_{2}$ and $700 \mathrm{~mL}$ of ice water. The $\mathrm{CH}_{2} \mathrm{Cl}_{2}$ layer was removed, and the $\mathrm{H}_{2} \mathrm{O}$ layer was extracted with $\mathrm{CH}_{2} \mathrm{Cl}_{2}$. The collected organic layers 
were washed with $200 \mathrm{~mL}$ of $\mathrm{H}_{2} \mathrm{O}$, dried with $\mathrm{MgSO}_{4}$, and concentrated to yield $255 \mathrm{~g}(97 \%)$ of pure product. ${ }^{1} \mathrm{H}$ NMR $\left(\mathrm{CDCl}_{3}\right): \delta=7.8(2 \mathrm{H}, \mathrm{d}, \mathrm{Ts}), 7.4-7.25(7 \mathrm{H}, \mathrm{m}, \mathrm{Ph}$ and $\mathrm{Ts}), 4.5$ $\left(2 \mathrm{H}, \mathrm{s}, \mathrm{OCH}_{2} \mathrm{Ph}\right), 4.2\left(2 \mathrm{H}, \mathrm{t}, 3 \mathrm{~J}=4.7 \mathrm{~Hz}, \mathrm{CH}_{2} \mathrm{OTs}\right), 3.7(2 \mathrm{H}, \mathrm{t}$, 3] $\left.=4.7 \mathrm{~Hz}, \mathrm{CH}_{2} \mathrm{CH}_{2} \mathrm{OTs}\right), 2.45\left(3 \mathrm{H}, \mathrm{s}, \mathrm{CH}_{3}\right) .{ }^{13} \mathrm{C} \mathrm{NMR}$ $\left(\mathrm{CDCl}_{3}\right): \delta=144.7,132.8,129.7127 .8$ (Ts), 137.5, 128.3, 127.7, $127.5(\mathrm{Ph}), 73.0\left(\mathrm{CH}_{2} \mathrm{Ph}\right), 21.5\left(\mathrm{PhCH}_{3}\right), 69.2,67.4$.

2-(Tetrahydropyran-2-yloxy)ethyl Tosylate, (35). TsCl (15 g, $78.7 \mathrm{mmol}$ ) was added to an ice-cooled mixture of ethylene glycol $(19 \mathrm{~g}, 306 \mathrm{mmol})$ and $35 \mathrm{~mL}$ of pyridine. The clear solution was stirred at $4{ }^{\circ} \mathrm{C}$ overnight, after which the reaction mixture was poured into $80 \mathrm{~mL}$ of ice water. Ether and a $1 \mathrm{M} \mathrm{HCl}$ solution were added, so that the $\mathrm{H}_{2} \mathrm{O}$ layer became acidic $(\mathrm{pH}=2)$. Separation of the two layers, further extraction of the aqueous layer with $\mathrm{Et}_{2} \mathrm{O}$, drying of the collected organic layers $\left(\mathrm{MgSO}_{4}\right)$, and evaporation of the solvent yielded crude product. Silica column chromatography with sequentially PhMe/E tOAc (10/1)-to remove the ditosylated side product $\left(R_{f}(\mathrm{PhMe} / \mathrm{EtOAc}(10 / 1)\right.$, silica $\left.)=0.35\right)-$ and EtOAc-to collect the product-afforded the monotosylated glycol as a clear oil in a yield of $8.1 \mathrm{~g}(48 \%)$. The spectroscopic data of this compound were in agreement with those found in the literature. ${ }^{37}{ }^{1} \mathrm{H}$ NMR $\left(\mathrm{CDCl}_{3}\right): \delta=7.8(2 \mathrm{H}, \mathrm{d}, \mathrm{Ts}), 7.35$ $\left.(2 \mathrm{H}, \mathrm{d}, \mathrm{Ts}), 4.1(2 \mathrm{H}, \mathrm{t}, \mathrm{TsOCH})_{2}\right), 3.8\left(2 \mathrm{H}, \mathrm{t}, \mathrm{CH}_{2} \mathrm{OH}\right), 3.0(1 \mathrm{H}$, bs, $\mathrm{OH}), 2.45\left(3 \mathrm{H}, \mathrm{s}, \mathrm{PhCH}_{3}\right) .{ }^{13} \mathrm{C} \mathrm{NMR}\left(\mathrm{CDCl}_{3}\right): \delta=145.0$, 132.3, 129.8, 127.8 (Ts), $71.6\left(\mathrm{CH}_{2} \mathrm{CH}_{2} \mathrm{OH}\right), 60.3\left(\mathrm{CH}_{2} \mathrm{OH}\right)$, and $21.5\left(\mathrm{PhCH}_{3}\right)$. TLC: $\mathrm{R}_{\mathrm{f}}(\mathrm{PhMe} / \mathrm{EtOAC}(10 / 1)$, silica $)=0.10 ; \mathrm{R}_{\mathrm{f}}$ $(E$ tOAc, silica $)=0.60$. Monotosyl ethylene glycol $(20 \mathrm{~g}, 92.6$ $\mathrm{mmol})$ and DHP $(8.9 \mathrm{~g}, 106 \mathrm{mmol})$ were dissolved in $40 \mathrm{~mL}$ of dry $\mathrm{Et}_{2} \mathrm{O}$. A catalytic amount of $\mathrm{TsOH} \cdot \mathrm{H}_{2} \mathrm{O}(0.10 \mathrm{~g})$ was added to the ice-cooled ethereal solution, and the mixture was stirred for $24 \mathrm{~h}$. Subsequently, the reaction mixture was washed with a saturated $\mathrm{NaHCO}_{3}$ solution. The $\mathrm{Et}_{2} \mathrm{O}$ layer was dried with $\mathrm{MgSO}_{4}$ and concentrated to afford a clear oil. Yield: $26.9 \mathrm{~g}$

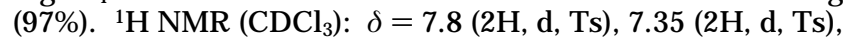
$4.55\left(1 \mathrm{H}, \mathrm{t}, \mathrm{OCHRO}\right.$ of the THP group), $4.2\left(2 \mathrm{H}, \mathrm{m}, \mathrm{TsOCH}_{2}\right)$, $3.85(1 \mathrm{H}, \mathrm{m}), 3.75(1 \mathrm{H}, \mathrm{m}), 3.65(1 \mathrm{H}, \mathrm{m}), 3.45(1 \mathrm{H}, \mathrm{m}), 2.45$ $\left(3 \mathrm{H}, \mathrm{s}, \mathrm{CH}_{3} \mathrm{Ph}\right), 1.8-1.4(6 \mathrm{H}, \mathrm{m}) .{ }^{13} \mathrm{C} \mathrm{NMR}\left(\mathrm{CDCl}_{3}\right): \delta=144.7$, 132.3, 129.7, 127.9 (Ts), 98.6 (OCHRO of the THP group), 21.5 $\left(\mathrm{PhCH}_{3}\right), 30.1,25.2,15.2\left(\mathrm{OCH}_{2} \mathrm{CH}_{2} \mathrm{CH}_{2} \mathrm{CH}_{2} \mathrm{CHO}_{2}\right.$ of the THP group), 69.3, 64.6, and 61.8. TLC: $\mathrm{R}_{f}$ (PhMe/EtOAC (5/1), silica) $=0.35$.

2-((2-Methoxyethoxy)methoxy)ethyl Tosylate (36). Monotosyl ethylene glycol (described in the experimental preparation of compound 35) $(1.0 \mathrm{~g}, 4.6 \mathrm{mmol})$ was stirred in $10 \mathrm{~mL}$ of ice-cooled $\mathrm{CH}_{2} \mathrm{Cl}_{2}$. Sequentially, diisopropylamine $(0.9 \mathrm{~g}, 7.0 \mathrm{mmol})$ and $\mathrm{MEMCl}(0.85 \mathrm{~g}, 6.8 \mathrm{mmol})$ were added. After $15 \mathrm{~min}$ the ice bath was removed and the reaction mixture was stirred overnight (after $3 \mathrm{~h}$ the reaction was not yet complete). The mixture was diluted with $30 \mathrm{~mL}$ of $\mathrm{CH}_{2-}$ $\mathrm{Cl}_{2}$, before it was washed sequentially with a $1 \mathrm{M} \mathrm{HCl}$ solution $(10 \mathrm{~mL})$, with a saturated $\mathrm{NaHCO}_{3}$ solution $(5 \mathrm{~mL})$, and with $\mathrm{H}_{2} \mathrm{O}(5 \mathrm{~mL})$. The organic layer was dried with $\mathrm{MgSO}_{4}$ and was concentrated. Silica column chromatography with $\mathrm{CH}_{2-}$ $\mathrm{Cl}_{2} /$ EtOAc (10/1) gave $1.2 \mathrm{~g}$ (85\%) of product. ${ }^{1} \mathrm{H}$ NMR $\left(\mathrm{CDCl}_{3}\right): \delta=7.8(2 \mathrm{H}, \mathrm{d}, \mathrm{Ts}), 7.35(2 \mathrm{H}, \mathrm{d}, \mathrm{Ts}), 4.7(2 \mathrm{H}, \mathrm{s}$, $\left.\left.\mathrm{OCH}_{2} \mathrm{O}\right), 4.2(2 \mathrm{H}, \mathrm{t}, \mathrm{TsOCH})_{2}\right), 3.8(2 \mathrm{H}, \mathrm{t}), 3.65(2 \mathrm{H}, \mathrm{t}), 3.55$ $(2 \mathrm{H}, \mathrm{t}), 3.35(2 \mathrm{H}, \mathrm{t}), 2.45\left(3 \mathrm{H}, \mathrm{s}, \mathrm{PhCH}_{3}\right) .{ }^{13} \mathrm{C} \mathrm{NMR}\left(\mathrm{CDCl}_{3}\right)$ : $\delta=144.8,132.9,129.8,127.9(\mathrm{Ts}), 95.4\left(\mathrm{OCH}_{2} \mathrm{O}\right), 21.6$ $\left(\mathrm{PhCH}_{3}\right), 58.9\left(\mathrm{OCH}_{3}\right), 71.6,69.1,66.8,65.1$.

2-(2-(Benzyloxy)ethoxy)ethyl Tosylate (37). ${ }^{11}$ Diethylene glycol $(369.5 \mathrm{~g}, 3.49 \mathrm{~mol})$, benzyl chloride $(67.9 \mathrm{~g}, 0.54 \mathrm{~mol})$, and $300 \mathrm{~mL}$ of a $1: 1(\mathrm{w} / \mathrm{w}) \mathrm{NaOH} / \mathrm{H}_{2} \mathrm{O}$ solution were transferred to a $2 \mathrm{~L}$ flask. The mixture was heated at reflux for 24 h. The solution, which had adopted a deep brown color, was poured into $700 \mathrm{~mL}$ of $\mathrm{H}_{2} \mathrm{O}$, and the resulting mixture was extracted with $\mathrm{Et}_{2} \mathrm{O}(4 \times 400 \mathrm{~mL})$. The collected organic layers were dried $\left(\mathrm{MgSO}_{4}\right)$ and concentrated. The residue was distilled $\left(100^{\circ} \mathrm{C}, 0.01 \mathrm{mmH}\right.$ ) and gave a slightly yellow clear oil (benzyl diethylene glycol). Yield: $86.3 \mathrm{~g}$ (82\%). The spectroscopic data of the compound were in agreement with those found in the literature. ${ }^{15,38}{ }^{1} \mathrm{H} \mathrm{NMR}\left(\mathrm{CDCl}_{3}\right): \delta=7.4-$ $7.3(5 \mathrm{H}, \mathrm{m}, \mathrm{Ph}), 4.55\left(2 \mathrm{H}, \mathrm{s}, \mathrm{OCH}_{2} \mathrm{Ph}\right), 3.8-3.55(8 \mathrm{H}, \mathrm{m}), 2.85$ $(1 \mathrm{H}, \mathrm{t}, \mathrm{OH}) .{ }^{13} \mathrm{C} \mathrm{NMR}\left(\mathrm{CDCl}_{3}\right): \delta=137.6,128.3,127.7,127.6$ (Ph), $73.1\left(\mathrm{OCH}_{2} \mathrm{Ph}\right), 72.4,70.3,69.3$, and $61.6\left(\mathrm{CH}_{2} \mathrm{OH}\right)$. TLC: $R_{f}$ (hexane/EtOAc (1/1), silica) $=0.10$. The alcohol $(207.6$ g $1.06 \mathrm{~mol}), \mathrm{TsCl}(202.8 \mathrm{~g}, 1.06 \mathrm{~mol})$, and $500 \mathrm{~mL}$ of $\mathrm{CH}_{2} \mathrm{Cl}_{2}$ were mixed in a $2 \mathrm{~L}$ flask. The solution was cooled in a salty ice bath. Freshly powdered $\mathrm{KOH}(85 \%, 237.5 \mathrm{~g}, 3.60 \mathrm{~mol})$ was added in small portions, while keeping the temperature of the suspension below $5{ }^{\circ} \mathrm{C}$. The mixture was stirred overnight at $4{ }^{\circ} \mathrm{C}$ and was then poured into $300 \mathrm{~mL}$ of $\mathrm{CH}_{2} \mathrm{Cl}_{2}$ and $700 \mathrm{~mL}$ of ice water. The $\mathrm{CH}_{2} \mathrm{Cl}_{2}$ layer was separated, and the $\mathrm{H}_{2} \mathrm{O}$ layer was extracted with $150 \mathrm{~mL}$ of $\mathrm{CH}_{2} \mathrm{Cl}_{2}$. The collected organic layers were washed with $200 \mathrm{~mL}$ of $\mathrm{H}_{2} \mathrm{O}$, dried with $\mathrm{MgSO}_{4}$, and concentrated to yield $361 \mathrm{~g}(97 \%)$ of pure title product. The spectroscopic data of the compound were in agreement with those found in the literature. ${ }^{11}{ }^{1} \mathrm{H}$ NMR $\left(\mathrm{CDCl}_{3}\right): \delta=7.85(2 \mathrm{H}, \mathrm{d}, \mathrm{Ts}), 7.4-7.25(7 \mathrm{H}, \mathrm{m}, \mathrm{Ph}$ and $\mathrm{Ts})$, $4.55\left(2 \mathrm{H}, \mathrm{s}, \mathrm{OCH}_{2} \mathrm{Ph}\right), 4.2(2 \mathrm{H}, \mathrm{t}), 3.7(2 \mathrm{H}, \mathrm{t}), 3.6-3.5(4 \mathrm{H}, \mathrm{m})$ $2.45\left(3 \mathrm{H}, \mathrm{s}, \mathrm{PhCH}_{3}\right) .{ }^{13} \mathrm{C} \mathrm{NMR}\left(\mathrm{CDCl}_{3}\right): \delta=138.0,128.4$, 127.7, 127.6 (Ph), 144.7, 132.9, 129.8, 127.9 (Ts), $73.2\left(\mathrm{OCH}_{2^{-}}\right.$ $\mathrm{Ph}), 21.6\left(\mathrm{PhCH}_{3}\right), 70.8,69.3,69.2$, and 68.8. TLC: $\mathrm{R}_{\mathrm{f}}(\mathrm{EtOAC}$, silica) $=0.65$.

Acknowledgment. J oost van Dongen, Henry Snijders, Henk Eding, and Wieb Kingma are acknowledged for mass spectroscopy results, elemental analyses, and SEC measurements. DSM Research is gratefully acknowledged for an unrestricted research grant.

\section{References and Notes}

(1) This is the first part of a back-to-back article sequence. In a previous communication, the first results on this research topic have been published: J anssen, H. M.; Peeters, E.; van Zundert, M. F.; van Genderen, M. H. P.; Meijer, E. W. Angew. Chem. 1997, 109, 152 (Angew. Chem., Int. Ed. Engl. 1997, 36, 122).

(2) Tuzar, Z.; Kratochvil, P. In Micelles of block and graft copolymers in solutions, surfaceand col loid science; Matijevic, E., Ed.; Plenum Press: New York, 1993; Vol. 15, pp 1-85. Riess, G.; Nervo, J .; Rogez, D. Polym. Eng. Sci. 1977, 8, 634 Gallot, Y.; Selb, J .; Marie, P.; Rameau, A. Polym. Prep. (Am. Chem. Soc., Div. Polym. Chem.) 1982, 23, 16. Desjardins, A.; Eisenberg, A. Macromol ecules 1991, 24, 5779. Xu, R.; Winnik M. A.; Riess, G.; Chu, B.; Croucher, M. D. Macromolecules 1992, 25, 644. Astafieva, I.; Zhong, X. F.; Eisenberg, A. Macromolecules 1993, 26, 7339. Denton, J. M.: Duecker, D. C.; Sprague, E. D. J . Phys. Chem. 1993, 97, 756. Toncheva, V.; Velichkova, R.; Trossaert, G.; Goethals, E. J . Polym. Int. 1993, 31, 335

(3) Schulz, D. N.; Bock. J .; Valint, P. L. In Macromolecular complexes in chemistry and biology; Dubin, P., Bock, J ., Davis, R., Schulz, D. N., Thies, C., Eds.; Springer-Verlag: Berlin, 1994; pp 3-13.

(4) Fuhrhop, J . H.; Koning, J . In Membranes and molecular assemblies: the synkinetic approach; Stoddart, J . F., Ed.; Monographs in Supramolecular Chemistry; Royal Society of Chemistry: Cambridge, 1994. Menger, F. M.; Littau, C. A. J . Am. Chem. Soc. 1993, 115, 10083.

(5) Newkome, G. R.; Moorefield, C. N.; Baker, G. R.; J ohnson, A. L.; Behara, R. K. Angew. Chem. 1991, 103, 1205. Newkome, G. R.; Moorefield, C. N.; Baker, G. R.; Saunders, M. J .; Grossman, S. H. Angew. Chem. 1991, 103, 1207. Newkome, G. R.; Young, J. K.; Baker, G. R.; Potter, R. L.; Audoly, L.; Cooper, D.; Weiss, C. D. Macromolecules 1993, 26, 2394. Newkome, G. R.; Moorefield, C. N.; Keith, J. M.; Baker, G. R.; Escamilla, G. H. Angew. Chem. 1994, 106, 701. Young, J. K.; Baker, G. R.; Newkome, G. R.; Morris, K. F.; J ohnson, C. S., J r. Macromol ecules 1994, 27, 3464. Tomalia, D. A.; Berry, V.; Hall, M.; Hedstrand, D. Macromolecules 1987, 20, 1164. Caminati, G.; Turro, N.J .; Tomalia, D. A. J . Am. Chem. Soc. 1990, 112, 8515. Gopidas, K. R.; Leheny, A. R.; Caminati, G.; Turro, N. J .; Tomalia, D. A. J . Am. Chem. Soc. 1991, 113, 7335. Turro, N. J .; Barton, J . K.; Tomalia, D. A. Acc. Chem. Res. 1991, 24, 332. Hawker, C. J .; Wooley, K. L.; Fréchet, J. M. J.J . Am. Chem. Soc. 1993, 115, 4375. Hawker, C. J.; Wooley, K. L.; Fréchet, J . M. J . J . Chem. Soc., Perkin Trans. 1 1993, 1287. Van Hest, J. C. M.; Baars, M. W. P. L.; Delnoye D. A. P.; van Genderen, M. H. P.; Meijer, E. W. Science 1995, 268, 1592. Van Hest, J . C. M.; Baars, M. W. P. L.; ElissenRomán, C.; van Genderen, M. H. P.; Meijer, E. W. Macromolecules 1995, 28, 6689. Van Hest, J . C. M.; Delnoye, D. A P.; Baars, M. W. P. L.; Elissen-Román, C.; van Genderen, M. H. P.; Meijer, E. W. Chem. Eur. J . 1996, 2, 1616. Chapman, 
T. M.; Hillyer, G. L.; Mhan, E.J .; Shaffer, K. A.J . Am. Chem. Soc. 1994, 116, 11195.

(6) Stryer, L. Biochemistry, 4th ed.; W. H. Freeman \& Company: New York, 1995. Crick, F. H. C. Acta Crystallogr. 1953, 6, 689. O'Shea, E.; Klemm, J . D.; Kim, P. S.; Alber, T. Science 1991, 254, 539. Hodges, R. S. Curr. Biol. 1992, 2, 122.

(7) The solubility of polypropylene oxide (PPO) in $\mathrm{H}_{2} \mathrm{O}$ is very sensitive to temperature changes: up to $15^{\circ} \mathrm{C}$ PPO is soluble, and at higher temperatures aggregates form. Mortensen, $\mathrm{K}$.; Pedersen, J. S. Macromol ecules 1993, 26, 805.

(8) Chu, B.; Wu, G. Macromol. Symp. 1994, 87, 55 and references therein. Mortensen, K.; Brown, W. Macromolecules 1993, 26, 4128 and references therein. Yang, Z.; Pickard, S.; Deng, N. J .; Barlow, R.J .; Attwood, D.; Booth, C. Macromolecules 1994 27,2371 and references therein.

(9) The compounds (S)-12 and (S)-14 have been reported in: Perkins, M. V.; Kitching W.; König, W. A.; Drew, R. A. I.J . Chem. Soc., Perkin Trans. 1 1990, 2501. Cowie, J. M. G.; Hunter, H. W. Makromol. Chem. 1990, 191, 1393. Chiellini, E.; Galli, G.; Carrozzino, S. Macromol ecules 1990, 23, 2106.

(10) The compounds (S)-8, (S)-9, (S)-11, and (S)-13 have been reported in: Mori, K. Tetrahedron 1976, 32, 1101.

(11) Compound $\mathbf{3 7}$ has previously been reported in: Son, B.; Czech, B. P.; Bartsch, R. A. Tetrahedron Lett. 1985, 26, 1787. Naemura, K.; Fukunaga, R.; Komatsu, M.; Yamanaka, M.; Chikamatsu, H. Bull. Chem. Soc. J pn. 1989, 62, 83.

(12) This type of cyclization procedure has been introduced elsewhere. (a) Peeters, E.; J anssen, H. M.; van Zundert, M. F.; van Genderen, M. H. P.; Meijer, E. W. Acta Polym. 1996, 47, 485. (b) Bachrach, A.; Z̈ilkha, A. Eur. Polym. J . 1982, 18, 421.

(13) Mukaiyama, T.; Usui, M.; Saigo, K. Chem. Lett. 1976, 49.

(14) Compound $\mathbf{3 4}$ has previously been reported in: Weber, E. Chem. Ber. 1985, 118, 4439.

(15) Selve, C.; Achilefu, S.; Mansuy, L. Synth. Commun. 1990, 20, 799. Coudert, G.; Mpassi, M.; Guillaumet, G.; Selve, C. Synth. Commun. 1986, 16, 19.

(16) Corey, E.J .; Nicolaou, K. C. J . Am. Chem. Soc. 1974, 96, 5614.

(17) The ee values of (S)-7 and (S)-10 were determined by highpressure liquid chromatography (HPLC) on a Daicel $\mathrm{CR}(+)$ column and by gas chromatography (GC) on a capillary column with a permethylated $\beta$-cyclodextrin stationary phase, respectively. The GC column was processed at $90^{\circ} \mathrm{C}$.

(18) The stereochemistry in diazotation reactions has previously been investigated in: Koppenhoefer, B.; Trettin, U.; Figura, R.; Lin, B. Tetrahedron Lett. 1989, 30, 5109.

(19) The GC column was processed at 160 and $150^{\circ} \mathrm{C}$ for (S)-5 and (S)-6, respectively. The found contaminants showed slightly higher retention values than those for (S)-5 or (S)-6; comparable selectivities $\alpha$ of 1.036 and 1.051 were found for (S)-5 and (S)-6, respectively. Thus, the assumption that the contaminants correspond to the (R)-enantiomers is likely, especially considering the fact that the found ee values of $97.6 \%$ and $99.4 \%$ are in accordance with the expected ratios of ca. $97 \%$ and ca. $99.5 \%$ (these are the ee values of the starting compounds).

(20) O'Hagan, D.; Zaidi, N. A.J . Chem. Soc., Perkin Trans. 11993 2389. Khani, D.; Gutman, A. L.; Kohn, D. H. J . Polym. Sci., Part A: Polym. Chem. 1993, 31, 1221. Wallace, J . S.; Morrow, C. J .J . Polym. Sci., Part A: Polym. Chem. 1989, 27, 2553 and 3271. Binns, F.; Roberts, S. M.; Taylor, A.; Williams, C. F. J. Chem. Soc. Perkin Trans. 1 1993, 899.

(21) In ref $12 a$, the synthesis and polymerization of these oxocrown ethers has been described.

(22) Whitehouse, C. M.; Yamashita, M.; Fenn, J . B.; Dreyer, R. N. Anal. Chem. 1985, 57, 675.

(23) PPO is a polymeric test material for ES-MS measurements. Also for this polymer, only species with molecular weights lower than 3000 Dalton can be detected adequately.

(24) Turbid aqueous solutions of polymer $\mathbf{1}(1-5 \mathrm{mg} / \mathrm{mL})$, acquired by overnight stirring of $\mathbf{1}$ in $\mathrm{H}_{2} \mathrm{O}$, did not phase separate on standing. Centrifugation for $2 \mathrm{~min}$ at a rotation rate of 3400 rpm resulted in a solution that still was turbid. Centrifugation for $10 \mathrm{~min}$ at $4300 \mathrm{rpm}$ gave a white precipitate in a clear solution. Stirring gave an immediate restoration of the turbid solution $\left(A_{700} \mathrm{~nm} \gg 1\right)$.

(25) The concentrations of the aqueous solutions were 0.8 and 3.7 $\mathrm{mg} / \mathrm{mL}$ for solutions of polymers $\mathbf{1}$ and $\mathbf{3}$ (entries $\mathrm{A}$ and I in Table 1), respectively.

(26) The cac's of cationic, anionic, and nonionic surfactants obtained with the fluorescent-probe technique were in agree ment with cac's obtained with other techniques: Kalyanasundaram, K.; Thomas, J. K. J . Am. Chem. Soc. 1977, 99, 2039.
(27) For examples of the application of fluorescent techniques in polymer characterization, see: (a) Macromol ecular complexes in chemistry and biology; Dubin, P., Bock, J ., Davies, R. M., Schulz, D. N., Thies. C., Eds.; Springer-Verlag: Berlin, 1994. Wilhelm, M.; Zhao, C.-L.; Wang, Y.; Xu, R.; Winnik, M. A.; Mura, J.-L.; Riess, G.; Croucher, M. D. Macromol ecules 1991, 24, 1033. Astafieva, I.; Zhong, X. F.; Eisenberg, A. Macromol ecules 1993, 26, 7339. (b) Yekta, A.; Xu, B.; Duhamel, J . Adiwidjaja, H., Winnik, M. A. Macromol ecules 1995, 28, 956. Yekta, A.; Duhamel, J .; Brochard, P.; Adiwidjaja, H.; Winnik, M. A. Macromolecules 1993, 26, 1829. Alami, E.; Almgren, M.; Brown, W.; François, J. Macromolecules 1996, 29, 2229.

(28) This technique is only viable when pyrene concentrations are small in comparison to the concentration of the polymer under investigation. This requirement is met in all experiments. A pyrene concentration of $4.1 \times 10^{-7} \mathrm{M}$ is usually applied in the measurements (the solubility of pyrene in $\mathrm{H}_{2} \mathrm{O}$ is approximately $2.5 \times 10^{-6} \mathrm{M}$ ).

(29) Alexandridis, P.; Holzwarth, J . F.; Hatton, T. A. Macromolecules 1994, 27, 2414.

(30) Alexandridis, P; Zhou, D.; Khan, A. Langmuir 1996, 12, 2690. Mortensen, K. Europhys. Lett. 1992, 19, 599. Wanka, G. Hoffmann, H.; Ulbricht, W. Macromolecules 1994, 27, 4145. Zhang, K.; Khan, A. Macromolecules 1995, 28, 3807. Alexandridis, P.; Olsson, U.; Lindmann, B. Macromolecules 1995, 28, 7700. Wu, G.; Ying, Q.; Chu, C. Macromolecules 1994, $27,5758$.

(31) For this study entry $C$ from Table 1 was used $\left(M_{n}=4.3, D\right.$ $=2.0$, determined with SEC, applying PS standards).

(32) These viscosity measurements were executed with U belohdes $(\mathrm{k}=0.01$; type $53010 / 1)$.

(33) Walderhaug, H.; Hansen, F. K.; Abramsén, S.; Persson, K.; Stilbs, P. J. Phys. Chem. 1993, 97, 8336. Water-soluble polymers; Glass, J. E., Ed.; Advances in Chemistry Series; American Chemical Society: Washington, D.C., 1986; Vol. 213. Polymers in aqueous media; Glass, J . E., Ed.; Advances in Chemistry Series; American Chemical Society: Washington, D.C., 1989; Vol. 223. ACS Symposium Series; Polymers as rheol ogy modifiers; Schulz, D. N., Glass, J . E., Eds.; ACS Symposium Series; American Chemical Society: Washington, D.C., 1991; Vol. 462.

(34) Kirchner, J . G. Techniques of chemistry: Thin layer chromatography, 2nd ed.; J ohn Wiley \& Sons, Inc.: New York, 1978, Vol. XIV, pp 203-204 and 225. KI/I 2 liquid: $I_{2}$ is dissolved in an aqueous $10 \% \mathrm{KI}$ solution until a $5 \%$ iodine concentration is reached. The solution is deep brown and may contain undissolved $\mathrm{I}_{2}$. Spray the solution on a TLC plate. In most cases a brown fixation is observed, but when compounds are dilute, gray fixations are possible. p-Anisaldehyde liquid: Mix $1 \mathrm{~mL}$ of p-anisaldehyde, $5 \mathrm{~mL}$ of sulfuric acid, $5 \mathrm{~mL}$ of glacial acid, and $90 \mathrm{~mL}$ of EtOH. Spray the liquid on the TLC plate and heat it. After $0.5 \mathrm{~min}$ spots appear. In most cases a purple fixation is observed. Other colors are also possible: molecules bearing a THP protecting group, for instance, give a greenblack fixation. Tosylates generally give white fixations.

(35) The g value is the dissymmetry factor of a Cotton effect; it is defined as the ratio between the difference in specific absorbance of right and left circularly polarized light and the specific absorbance, $g=\Delta \epsilon / \epsilon$ ). See: Eliel, E. L.; Wilen, S. H. Stereochemistry of organic compounds; Wiley: New York, 1994.

(36) Mahboobhi, S. Helv. Chim. Acta 1988, 71, 2034.

(37) Bradshaw, J . S.; Krakowiak, K. E.; Lindh, G. C.; Izatt, R. M. Tetrahedron 1987, 43, 4271.

(38) Fyles, T. M.; Mc Gavin, C. A.; Whitfield, D. M. J . Org. Chem. 1984, 49, 753 .

(39) Systems without salt bridges are also known to form coiled coils. Recently, it has been argued that the salt bridges ('charge-charge' interactions) between residues $\mathrm{E}$ and $\mathrm{G}$ ' and between $\mathrm{E}^{\prime}$ and $\mathrm{G}$ do not necessarily contribute favorably to the dimerization of $\alpha$-helices and may be unfavorable relative to the alternative 'neutral-charge' interactions. Lumb, K.J .; Kim, P. S. Science 1995, 268, 436. Lavigne, P.; Sönnichsen, F. D.; Kay, C. M.; Hodges, R. S.; Lumb, K. J'; Kim, P. S. Science 1995, 271, 1137.

(40) Entries A, E, H, and N (see Table 1) have been used for parts $A, B, C$, and D, respectively, so every mode of polymerization -ring-opening polymerization and polycondensation either with or without SnOct 2 catalyst-is represented in these ESMS-measurements. For the methyl-substituted polymer (entry $\mathrm{H}$ ), no $\mathrm{CH}_{3} \mathrm{COONH}_{4}$ salt was added to the investigated solution. 